\title{
Tracing Water and Carbon Sources in Complex Geochemical Settings of the Appalachians: An Isotopic Perspective
}

Andrea L. Sack

West Virginia University

Follow this and additional works at: https://researchrepository.wvu.edu/etd

\section{Recommended Citation}

Sack, Andrea L., "Tracing Water and Carbon Sources in Complex Geochemical Settings of the Appalachians: An Isotopic Perspective" (2012). Graduate Theses, Dissertations, and Problem Reports. 4915.

https://researchrepository.wvu.edu/etd/4915

This Thesis is protected by copyright and/or related rights. It has been brought to you by the The Research Repository @ WVU with permission from the rights-holder(s). You are free to use this Thesis in any way that is permitted by the copyright and related rights legislation that applies to your use. For other uses you must obtain permission from the rights-holder(s) directly, unless additional rights are indicated by a Creative Commons license in the record and/ or on the work itself. This Thesis has been accepted for inclusion in WVU Graduate Theses, Dissertations, and Problem Reports collection by an authorized administrator of The Research Repository @ WVU. For more information, please contact researchrepository@mail.wvu.edu. 


\title{
Tracing Water and Carbon Sources in Complex Geochemical Settings of the Appalachians: An Isotopic Perspective
}

\author{
Andrea L. Sack \\ Thesis submitted to the Eberly College of Arts and Sciences \\ at West Virginia University \\ in partial fulfillment of the requirements \\ for the degree of
}
Master of Science
in
Geology

\begin{abstract}
Dr. Shikha Sharma, Chair
Dr. Dorothy Vesper, WVU

Dr. Hank Edenborn, NETL
\end{abstract}

Key words: isotope, geochemistry, carbon, water, Appalachians

Copyright @ 2012 Andrea L. Sack 


\title{
ABSTRACT \\ Tracing Water and Carbon Sources in Complex Geochemical Settings of the Appalachians: An Isotopic Perspective
}

\begin{abstract}
Andrea L. Sack
Understanding sources of water and carbon are important for tracking recharge sources as well as assessing any changes in water quality associated with shale gas drilling and/or coal mining in the Appalachians. Natural stable isotopes have become an increasingly important tool for determining sources and cycling of water, carbon, nutrients and other trace elements. This is plausible because variations in water-rock interactions, recharge sources, recharge pathways, and residence time can impart unique isotopic fingerprints to different water sources.

The main objective of this study was to use stable isotopes of water $\left(\delta^{18} \mathrm{O}_{\mathrm{H} 2 \mathrm{O}}\right.$ and $\left.\delta^{2} \mathrm{H}_{\mathrm{H} 2 \mathrm{O}}\right)$, DIC $\left(\delta^{13} \mathrm{C}_{\mathrm{DIC}}\right)$ and $\mathrm{SO}_{4}\left(\delta^{34} \mathrm{~S}_{\mathrm{SO} 4}\right.$ and $\left.\delta^{18} \mathrm{O}_{\mathrm{SO} 4}\right)$ to delineate sources of water and carbon in three different geochemical settings in Appalachians: natural springs, coal mine discharges and co-produced waters produced during Marcellus shale gas drilling in the Appalachian region. At some study sites other geochemical proxies such as major cations, anions (i.e. $\mathrm{Na}^{+}, \mathrm{Ca}^{2+}, \mathrm{Mg}^{2+}, \mathrm{HCO}_{3}{ }^{-}, \mathrm{SO}_{4}{ }^{2-}$ ) as well as field parameters (temperature and $\mathrm{pH}$ ) were used in conjunction with stable isotope data to better understand the underlying physical, geochemical and biological processes. Our data shows that stable isotopic signatures in natural springs, coal mine discharge and coproduced waters can be used understand sources of carbon and water at each site as well as understanding biogeochemical transformations that lead to isotopic fractionation.
\end{abstract}


Copyright @ 2012

by

Andrea L. Sack 


\section{ACKNOWLEDGEMENTS}

Graduate school has been an amazing experience for me and I have many people to thank for that. First off I would like to express my sincere gratitude to Dr. Shikha Sharma for being a great mentor and academic advisor. Dr. Sharma has been inspiring in the lab and classroom and I hope to take the knowledge I gained from her into my future career. I would also like to thank the West Virginia University Department of Geology and Geography for giving me the opportunity to continue my education and providing me with the support to do so. Additionally, I would like to thank the DOE/NETL for providing me the funds to carry out my research. My experience would not have been the same without my fellow graduate students and lab workers, so thanks for the help and support. Finally, to my close friends and family for encouraging me to keep motivated and working hard throughout the years.

Thanks :;

Andrea 


\section{TABLE OF CONTENTS}

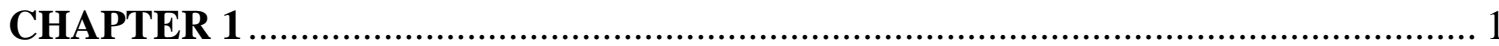

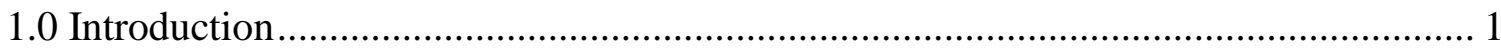

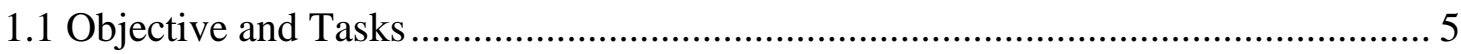

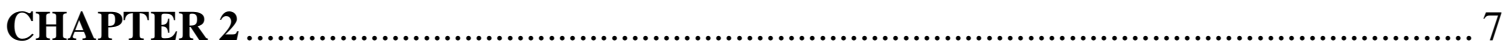

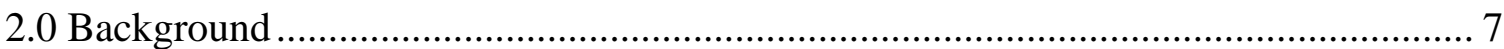

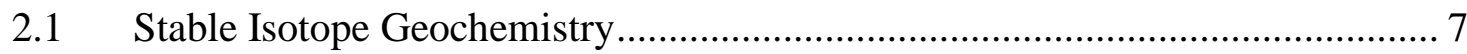

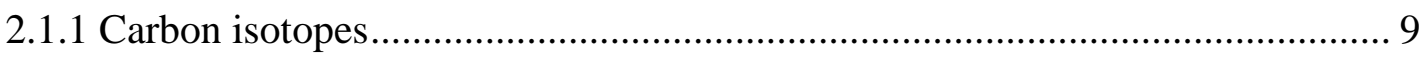

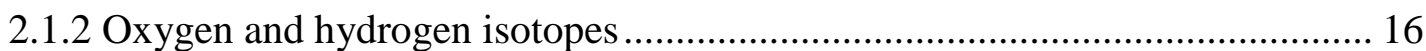

2.1.3 Sulfur and oxygen isotopes of dissolved sulfate............................................. 21

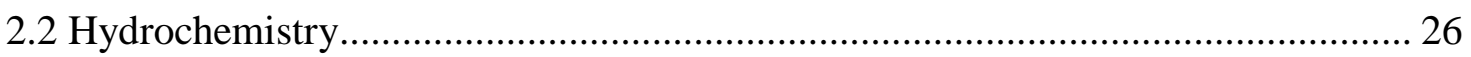

2.3 Applications of Stable Isotopes in the Environment............................................ 28

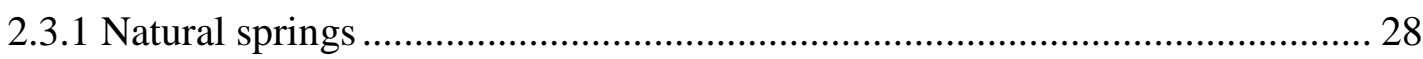

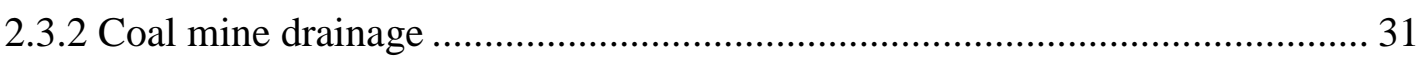

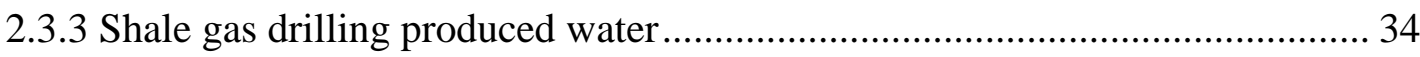

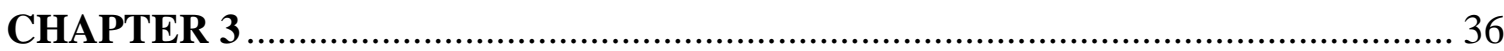

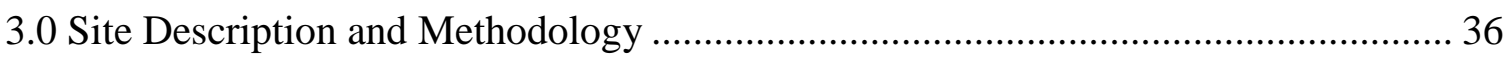

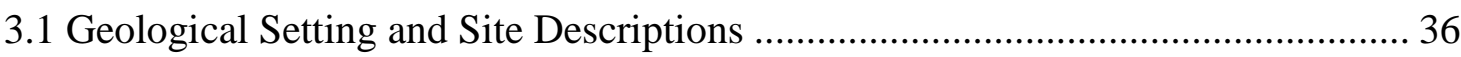

3.2 Sample Collection and Preparation..................................................................... 42

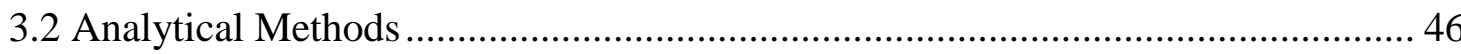

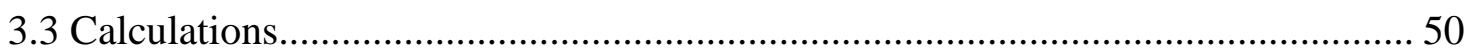

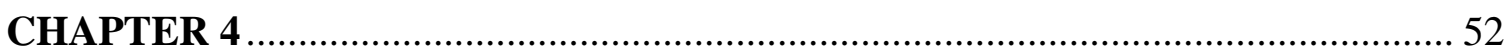

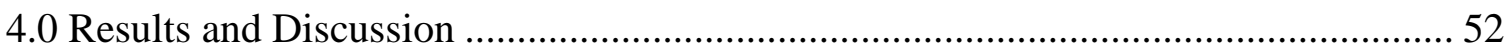

4.1 Oxygen and Hydrogen Isotope Composition of Waters ........................................ 52

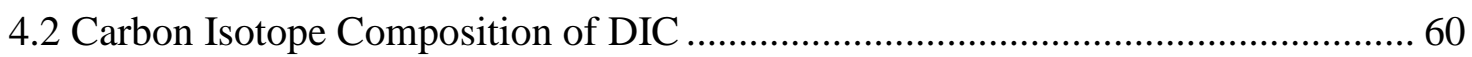

4.3 Sulfur and Oxygen Isotope Composition of Dissolved Sulfate .............................. 70

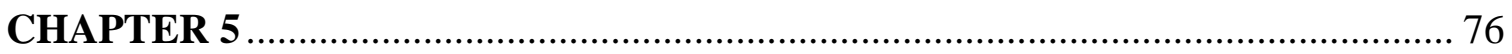

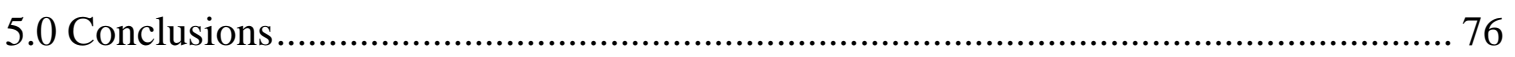

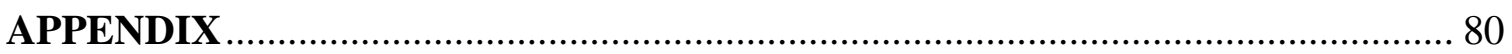

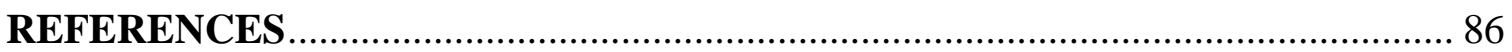




\section{LIST OF FIGURES AND TABLES}

Figure 1.0 - World population growth (modified from Soubbotin and Sheram, 2000)

Figure 1.1-Mine discharge portal at Iron Falls, Allegheny County, PA

Figure 2.0-Natural variations in $\delta^{13} \mathrm{C}$ in a range of compounds (modified from Clark and Fritz, 1997; Mook, 2001)

Figure 2.1-Distribution of carbonate species as a function of $\mathrm{pH}$ at $25^{\circ} \mathrm{C}$ (modified from Schulte et al., 2011)

Figure 2.2-Fractionation of ${ }^{13} \mathrm{C}$ between each aqueous species of $\mathrm{DIC}$, soil $\mathrm{CO}_{2}$, and calcite (modified from Clark and Fritz, 1997)

Figure 2.3-Global meteoric relationship between $\delta^{2} \mathrm{H}$ and $\delta^{18} \mathrm{O}$ in precipitation (modified from Clark and Fritz, 1997)

Figure 2.4-Deviation from the GMWL as a result of hydrological processes and different origin of the airmass (modified from SAHRA)

Figure 2.5-Natural variations in $\delta^{18} \mathrm{O}$ in a range of compounds (modified from Clark and Fritz, 1997; Mook, 2001)

Figure 2.6-Natural variations in $\delta^{2} \mathrm{H}$ in a range of compounds (modified from Clark and Fritz, 1997; Mook, 2001)

Figure 2.7-Exchange processes which alter the isotopic composition of meteoric waters (modified from Clark and Fritz, 1997)

Figure 2.8-Natural variations in $\delta^{34} \mathrm{~S}$ in a range of compounds (modified from Clark and Fritz, 1997; Mook, 2001; Krouse, 1980)

Figure 2.9-Geocehmical pathways which result in sulfur fractionation

Figure 3.0 - Map of study area and sampling locations

Figure 3.1-Tufa deposits at spring sites in Pennsylvania

Figure 3.2-Modified stratigraphic column for spring sites in Pennsylvania

Figure 3.3-Iron falls; coal mine discharge site in Allegheny Co., PA

Figure 3.4-Modified stratigraphic column for Iron Falls

Figure 3.5-Extent of Marcellus shale formation (Soeder and Kappel, 2009)

Figure 3.6-Shale gas drilling site in Greene Co., PA

Figure 3.7-GasBench II device coupled with isotope ratio mass spectrometer (IRMS) and PAL autosampler at WVU Stable Isotope Lab

Figure 3.8- $-\mathrm{BaSO}_{4}$ precipitation set-up

Figure 3.9-Schematic of GasBench II interfaced to IRMS (Torres et al., 2005) 
Figure 3.10 - Chromatogram produced by ISODAT 3.0 software system

Figure 3.11 - Platinum catalyst for $\mathrm{D} / \mathrm{H}$ ratio measurements

Figure 4.0- $\mathrm{H}$ and $\mathrm{O}$ values of water plotted against GMWL and LMWL

Figure 4.1-Close-up on natural springs and coal mine discharge site $\mathrm{H}$ and $\mathrm{O}$ values of water

Figure 4.2-Flowback samples with published Appalachian brine data (modified from Siegel et al., 2004, 1990)

Figure 4.3-Primary and secondary trajectories of brine-forming processes (GMWL) (modified from Horita, 2005)

Figure 4.4-Surface water and frac water isotope values compared to sampled flowback water

Figure 4.5- $\delta^{13} \mathrm{C}_{\mathrm{DIC}}$ values of all sampling sites

Figure 4.6- $\delta^{13} \mathrm{C}_{\mathrm{DIC}}$ of springs and CMD samples with carbonate end-members

Figure 4.7- $\mathrm{Ca}^{2+}$ and $\mathrm{HCO}_{3}{ }^{-}$concentrations plotted against $\delta^{13} \mathrm{C}_{\text {DIC }}$ values for springs in $\mathrm{WV}$ and VA

Figure 4.8 - $\delta^{13} \mathrm{C}_{\mathrm{DIC}}$ vs. $\delta^{34} \mathrm{~S}$ of CMD samples compared to PA groundwater aquifers

Figure 4.9-Cation and bicarbonate concentrations compared to $\delta^{13} \mathrm{C}_{\text {DIC }}$ for CMD site

Figure 4.10 $-\delta^{34} \mathrm{~S}$ of dissolved sulfate vs. sulfate $\left(\mathrm{SO}_{4}{ }^{2-}\right)$ concentrations

Figure 4.11- $\delta^{18} \mathrm{O}$ versus $\delta^{34} \mathrm{~S}$ indicating different sources of sulfur

Table 2.0 - ${ }^{13} \mathrm{C}$ fractionation in the carbonate system (modified from Clark and Fritz, 1997)

Table 4.0-Percent carbonate carbon contribution from two end-member mixing model 


\section{LIST OF EQUATIONS}

Equation 2.0-Delta notation $(\delta)$ in permil units (\%o)

Equation 2.1-Equilibrium exchange reaction between $\mathrm{CO}_{2}$ and water

Equation 2.2- $\mathrm{CO}_{2}$ diffusion into water

Equation 2.3- $-\mathrm{CO}_{2}$ hydration

Equation 2.4-1 st dissociation of carbonic acid

Equation 2.5-2 $2^{\text {nd }}$ dissociation of carbonic acid

Equation 2.6-Sum of all carbon species which make up the total dissolved inorganic carbon (DIC)

Equation 2.7-Calcite dissolution reaction

Equation 2.8-Organic carbon oxidation by dissolved molecular oxygen

Equation 2.9-Isotope exchange reaction for S and $\mathrm{O}$

Equation 2.10 - Oxidation of fixed carbon by sulfate

Equation 2.11 - Oxidation of reduced carbon by sulfate

Equation 2.12-Oxidation of pyrite with $\mathrm{O}_{2}$ as the oxidizing agent

Equation 2.13-Oxidation of pyrite with $\mathrm{Fe}^{3+}$ as the oxidizing agent

Equation 2.14-Dissolution of gypsum

Equation 2.15-Commone ion effect where dissolution of sulfate forces calcite precipitation

Equation 2.16 - Oxidation of sulfide

Equation 2.17-Oxidation of thiosulfate and polythionate

Equation 2.18 - Oxidation of thiosulfate to produce dissolved sulfate

Equation 3.0-Equilibrium constant equation for the dissociation of carbonic acid

Equation 3.1-Equilibrium constant equation for bicarbonate dissociation

Equation 3.2-Temperature dependent Van't Hoff equation

Equation 4.0 - Local meteoric water line (LMWL) constructed from Bowen, (2012)

Equation 4.1-Global meteoric water line (GMWL) from Rosanski et al., (1993)

Equation 4.2 - Sulfuric acid-enhanced carbonate weathering

Equation 4.3-Carbonic acid weathering of $\mathrm{CaCO}_{3}$

Equation 4.4-Two end-member mixing equation

Equation 4.5-Cation exchange reaction

Equation 4.6-Formation of methane by $\mathrm{CO}_{2}$ reduction

Equation 4.7-Formation of methane by acetate fermentation

Equation 4.8-Sulfate reduction of $\mathrm{SO}_{4}{ }^{2-}$ to $\mathrm{H}_{2} \mathrm{~S}$ 


\section{ABBREVIATIONS, ACRONYMS AND SYMBOLS}

(aq)-Aqueous

CF-IRMS-Continuous Flow-Isotope Ratio Mass Spectrometry

CMD_Coal Mine Discharge

DIC-Dissolved Inorganic Carbon

DOC-Dissolved Organic Carbon

DOE_-Department of Energy

EA-Elemental Analyzer

EPA-Environmental Protection Agency

(g) - Gaseous

GC-Gas Chromatography

GMWL_Global Meteoric Water Line

GNIP-Global Network of Isotopes in Precipitation

$\mathbf{H}_{2} \mathrm{CO}_{3} *$-- Combined aqueous carbon dioxide $\left(\mathrm{CO}_{2(\mathrm{aq})}\right)$ and carbonic acid $\left(\mathrm{H}_{2} \mathrm{CO}_{3}\right)$

IAEA-International Atomic Energy Agency

IC-Ion Chromatography

ICP-OES - Inductively Coupled Plasma - Optical Emissions Spectroscopy

IRMS-Isotope Ratio Mass Spectrometry

LMWL_Local Meteoric Water Line

mya-Million Years Ago

NETL—National Energy and Technology Laboratory

ORP-Oxidation Reduction Potential

$\mathbf{P}_{\mathbf{C O} 2}$ - partial pressure $\mathrm{CO}_{2}$

PEP-Phosphoenol pyruvate

RuBP_Ribulose biphosphate

RuBisCO_Ribulose biphosphate carboxylase/oxygenase

TOC_-Total Organic Carbon

USGS-United States Geological Survey

VCDT_-Vienna Cañon Diablo Troilite

VPDB-Vienna Pee Dee Belemnite

VSMOW-Vienna Standard Mean Oceanic Water

WMO-World Meteorological Organization

WVSIL_-West Virginia Stable Isotope Laboratory 


\section{$\%$ w/w-Percent weight/weight \\ $\boldsymbol{\varepsilon}$--fractionation factor \\ \%o-permil unit (parts per thousand) \\ $\boldsymbol{\delta}$-delta notation}




\section{CHAPTER 1}

\subsection{Introduction}

Water is one of our most

critical natural resource that is

currently under stress. Though 70

$\%$ of the world is covered in

water, only about $0.76 \%$ of

water is freshwater and

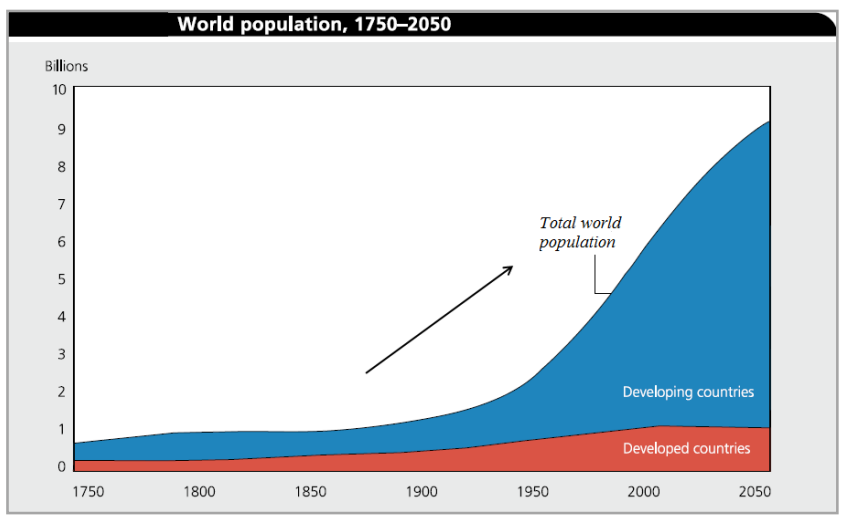

Figure 1.0-World population growth. Note the sharp available for use. While the increase in population (modified from Soubbotin and Sheram, 2000).

amount of freshwater around the world has remained relatively constant, continually being recycled by earth's natural processes, the world's population has exploded in the past 50 years and is predicted to continue to increase (Soubbotin and Sheram, 2000) (Fig. 1.0). Within the next 15 years, it is projected that the human population's water usage will increase to 6250 cubic kilometers of water per year, with a majority needed to grow food (Amano, 2011). In 2005, the United States Geological Survey (USGS) evaluated the sources of the nation's water and for what purposes the water was used. The two main sources of freshwater are surface water, such as rivers and lakes, and groundwater (USGS, 2005).

The high demand for water can have a direct impact on the quality of water and vice versa. As stream/river impoundments and groundwater wells are being depleted due to increased usage, various other problems also arise, for example saltwater intrusions 
from excess withdrawals, polluted runoff from excess water applied for irrigation and landscaping and altered surface water flows (EPA, 1995). These issues often result in increased concentrations and movement of pollutants (i.e. salts, metals, nutrients, bacteria/viruses etc.) along with disturbed natural flows. As the quality of our surface and groundwater resources continues to deteriorate, it has become increasingly important to develop water management strategies to maintain an adequate freshwater supply.

Surface waters and groundwaters can also play an important role in the global carbon cycle. Rivers are an essential component in transforming and transporting carbon. It has been estimated that rivers transport an average of 1 gigaton of carbon to the oceans per year (Ludwig et al., 1996). Conservative estimates suggest that carbon export from land to sea is approximately $50 \%$ of the total amount of carbon that inland waters receive from anthropogenic and natural sources (Cole et al., 2007). Dissolved inorganic carbon (DIC) contributes a large fraction to the total carbon pool and originates from three main sources: atmospheric $\mathrm{CO}_{2}$, carbonate dissolution and organic matter oxidation in the soil and/or river itself (Brunet et al., 2005). The physical and chemical erosion of carbonate rocks releases old sequestered carbon from the system, adding to the total DIC pool. The weathering of silicate and carbonate rocks consume atmospheric $\mathrm{CO}_{2}$ and produces dissolved carbon which can then be transported and transformed by surface and groundwater systems. This dissolved carbon can ultimately escape to the atmosphere via $\mathrm{CO}_{2}$ outgassing or can be transported in solution as DIC to oceans. Thus, there is a need to understand source and fate of carbon in waters flowing through a variety of geological, ecological and disturbed environments for better understanding the role of water in regional and global carbon budgets. 
This thesis is designed to test the applicability of stable isotopes to investigate sources of water and carbon in different geochemical settings of the Central Appalachian region. The Appalachian Basin was an area of sediment accumulation and two significant orogenies during the Paleozoic era ( 570 to 225 mya). The Appalachian orogeny occurred from 320-220 mya, mainly during the Pennsylvanian through mid- Triassic time periods. Coal-bearing and carboniferous rocks formed from sediments eroding these mountains. As deformation continued, the Appalachian Basin was faulted and folded. Erosion later created today what's known as the Valley and Ridge Province (Appendix C, EPA; Hobba, 1979). The complex composition and structure of the Appalachian region gives rise to different types of waters which contribute to surface and groundwater in this area.

The different kinds of waters being investigated in this study include water discharging from natural springs, coal mine discharge and co-produced water from shale gas drilling. The natural springs in the study area have been reliable sources of domestic water and development of recreational facilities and resorts since the late $18^{\text {th }}$ century (Rader and Gathright, 1984). Some studies have also highlighted the importance of thermal springs to produce geothermal power. A recent study suggests that certain areas of West Virginia may have the capacity to generate about 18,890 megawatts of power, which is about $75 \%$ higher than previously estimated (Kuykendall, 2010). In addition to natural springs, other discharge sources of water include mine discharge portals (Fig. 1.1). The water released from these portals is generally of poor quality due to substantial water-rock interactions releasing dissolved metals and acidity as well as significant biological activity occurring along the flowpaths (Gould and Kapoor, 2003). These 
water-rock interactions and biogeochemical processes can also affect the cycling of carbon on a local scale. Therefore, understanding sources of water and carbon are important for tracking recharge sources as well as assessing any changes in water quality associated with coal mining in the Appalachians.

Besides coal mining, other human-induced changes can also potentially impact the quantity and quality of water in this region. One

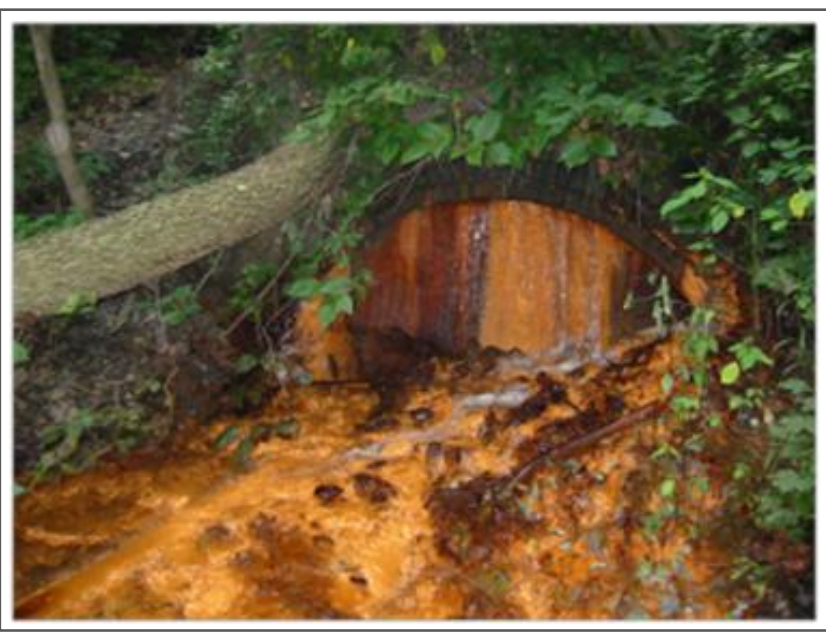

Figure 1.1-Mine discharge portal at Iron Falls in Allegheny County, PA. The portal was sealed in the late 1960s and since then has been discharging alkaline mine drainage into the Youghiogheny river.

of these changes is the rapidly expanding shale gas drilling in this region. Shale gas is an emerging unconventional resource which has the potential to provide energy to meet our Nation's growing demand. Growing environmental concerns associated with shale gas drilling include potential contamination of shallow fresh water sources and possible diminishing of fresh water supplies due to withdrawals for hydraulic fracturing of shales (Blauch et al., 2009). Hydraulic fracturing is a technique used in shale gas development where a water-sandchemical mix is pumped under high pressure, forming fractures in the rock which provide pathways for gas to move to the well (Soeder et al., 2009). This process, often referred to as hydraulic fracturing, may require 3 to 5 million gallons of water per well (Arthur et al., 2010). Highly saline water, or brine, co-produced as a result of the drilling process is known as flowback water. Flowback water is mixture of returning fracturing water, 
which was injected in the formation for hydraulic fracturing, and brine in the drilled/underlying/overlying formations. These brines have very high concentrations of dissolved constituents and are commonly considered more saline than sea water. High salinity of brines may be of concern if they leak into drinking water supplies or waters for agricultural uses (Hoyle and Dasch, 2012).

In the case of natural springs and coal mine discharge settings, waters are discharging to the surface but it is unknown whether they are receiving significant contributions from fresh water recharge/precipitation or whether they are discharging old water recharge over geological times scales. On the other hand, in the shale gas drilling environment, the question arises whether the recovered water is freshwater put in as "frac" water or is it the old existing brine in saline formations that is being released to the surface as flowback water. These geochemical settings therefore offer an opportunity for using geochemical tools to understand processes related to water cycling and water-rock interactions that may impact the quality of the water.

\subsection{Objective and Tasks}

The objective of this study is to test whether stable isotopes of water $\left(\delta^{18} \mathrm{O}_{\mathrm{H} 2 \mathrm{O}}\right.$ and $\left.\delta^{2} \mathrm{H}_{\mathrm{H} 2 \mathrm{O}}\right)$, DIC $\left(\delta^{13} \mathrm{C}_{\mathrm{DIC}}\right)$ and $\mathrm{SO}_{4}{ }^{2-}\left(\delta^{34} \mathrm{~S}_{\mathrm{SO} 4}\right.$ and $\left.\delta^{18} \mathrm{O}_{\mathrm{SO} 4}\right)$ can be used to delineate sources of water and carbon in three different geochemical settings in the Central Appalachian region i.e. natural springs, coal mine discharges and brines produced during shale gas drilling. My working hypothesis is that variations in recharge sources, water-rock interactions, and biogeochemical transformations will impart unique isotope signatures to water, dissolved inorganic carbon (DIC) and dissolved sulfate at these sites. 
The specific tasks which were undertaken to attain this objective included:

- Collected water samples from natural springs in Pennsylvania, West Virginia and Virginia; a coal mine discharge site located in Allegheny County, PA and brines produced during Marcellus shale gas drilling in Greene County, PA

- Analyzed samples for stable isotopes including $\delta^{18} \mathrm{O}_{\mathrm{H} 2 \mathrm{O}}, \delta^{2} \mathrm{H}_{\mathrm{H} 2 \mathrm{O}}, \delta^{13} \mathrm{C}_{\mathrm{DIC}}$ in the WVU Stable Isotope Laboratory

- Precipitated out dissolved sulfate as $\mathrm{BaSO}_{4}$ and sent it to the University of Arizona's Environmental Isotope Laboratory for analysis $\delta^{34} \mathrm{~S}_{\mathrm{SO} 4}$ and $\delta^{18} \mathrm{O}_{\mathrm{SO} 4}$

- Combined major cation and anion data as well as water quality parameters such as $\mathrm{pH}$ and temperature from Moore 2012 and Adams 2012 with isotopic data to better understand biogeochemical reactions in the different systems

- Plotted isotope and geochemical data on different geochemical plots to delineate sources of water and carbon at different sampling sites 


\section{CHAPTER 2}

\subsection{Background}

\subsection{Stable Isotope Geochemistry}

Atoms of the same element can have different numbers of neutrons; the different possible versions of each element are called isotopes. This variation in the number of neutrons in the nucleus results in a different atomic mass. Environmental isotopes are naturally occurring isotopes of elements found in abundance in our environment and are major components of hydrological, geological, and biological systems (Clark and Fritz, 1997). Isotopes can be classified as unstable, undergoing spontaneous radioactive decay, or as stable, which do not spontaneously disintegrate by decay. The specific elements and their isotopes focused on in this study are oxygen, hydrogen, carbon, and sulfur.

Isotopic compositions are expressed as the difference between the measured ratio of the heavy to light element (i.e. ${ }^{13} \mathrm{C} /{ }^{12} \mathrm{C}$ ratio) in the sample and in a reference material over the measured ratio of a reference material. This is expressed as delta notation $(\delta)$ by the equation:

$$
\delta=\left(\frac{R_{\text {sample }}}{R_{\text {standard }}}-1\right) \times 1000
$$

where $\mathrm{R}$ is the ratio of heavy to light isotopes in the sample and standard, respectively. Delta values $(\delta)$ are reported in permil, or parts per thousand notation $(\%)$ difference from the assigned IAEA reference standard. A positive $\delta$ value indicates that the ratio of heavy to light isotope is higher in the sample compared to the standard and is said to be "enriched" in the heavy isotope. A negative $\delta$ value indicates that the sample is "depleted" in the heavy isotope with respect to the standard. The International Atomic 
Energy Agency (IAEA) assigns appropriate materials as isotope reference standards to ensure standardization of measurements between laboratories. Oxygen and hydrogen are measured with respect to Vienna Standard Mean Ocean Water (VSMOW), carbon with respect to Vienna Pee Dee Belemnite (VPDB), and sulfate with respect to Vienna Cañon Diablo Troilite meteorite (VCDT). The isotope ratios are determined by measuring the mass differences of molecular compounds by use of gas source mass spectrometry.

Different physical, geochemical and/or biological processes can result in variations in ratios of heavy to light isotopes in different substrates found in nature. These isotopic variations are result of a process known as isotopic fractionation. Fractionation arises due to the difference in mass of the isotopes. This slight difference in mass leads to differences in the physiochemical properties and the reaction rates which can favor one isotope over another. There are two main ways to fractionate isotopes in a thermodynamic reaction: equilibrium fractionation and kinetic fractionation (Mook, 2001). Equilibrium fractionation occurs primarily in exchange reactions where the isotopes of an element are redistributed among chemical substances or physical change of state in a closed, well-mixed system. A good example of an equilibrium exchange reaction is between carbon dioxide and water in a closed system:

$$
\mathrm{C}^{16} \mathrm{O}_{2}+\mathrm{H}_{2}{ }^{18} \mathrm{O} \leftrightarrow \mathrm{C}^{18} \mathrm{O}_{2}+\mathrm{H}_{2}{ }^{16} \mathrm{O}
$$

where ${ }^{18} \mathrm{O}$ of the water exchanges with the oxygen in the $\mathrm{CO}_{2}$ molecule. During equilibrium fractionation processes, the heavier isotope preferentially accumulates in the species or compounds with a higher oxidation state and the denser phase. Unlike equilibrium fractionation, kinetic fractionation is usually associated with incomplete or 
unidirectional chemical, physical or biological processes. This type of fractionation generally imparts a larger difference and occurs at a much faster rate. During kinetic fractionation, the lighter isotope will react faster since they form weaker bonds within a compound. One example of kinetic fractionation is the processes of $\mathrm{CO}_{2}$ degassing where $\mathrm{CO}_{2}$ is lost to the atmosphere, consequently shifting the isotopic signature of the DIC remaining in solution to more enriched values.

As a consequence of fractionation processes, water and solutes develop a unique isotopic composition which is often indicative of their source and/or the biogeochemical processes they have undergone. Kinetic reactions such as biological processes frequently impart larger fractionation than the equilibrium reaction (Kendall and Caldwell, 1998). Different fractionation processes result in wide range of isotopic variations and hence can be used to understand geological, biological, physical and geochemical processes occurring in nature.

\subsubsection{Carbon isotopes}

Carbon has two naturally-occurring stable isotopes; ${ }^{12} \mathrm{C}$ and ${ }^{13} \mathrm{C}$. Naturally occurring environmental isotopes of carbon provide means of understanding carbon sources and a multitude of biogeochemical reactions. The international standard for carbon isotope measurement is Vienna Pee Dee Belemnite (VPDB), where the PBD was the internal calcite structure from a marine fossil Belemnitella americana from the Cretaceous Pee Dee Formation in South Carolina. This standard has been utilized for measurements of all carbon-containing compounds including $\mathrm{CO}_{2}$, dissolved inorganic carbon species (DIC), dissolved organic carbon species (DOC), cellulose and other fixedC solids, organic liquids, methane and other hydrocarbons (Clark and Fritz, 1997). 
The many species and forms of carbon each have varying $\delta^{13} \mathrm{C}$ in nature (Fig. 2.0).

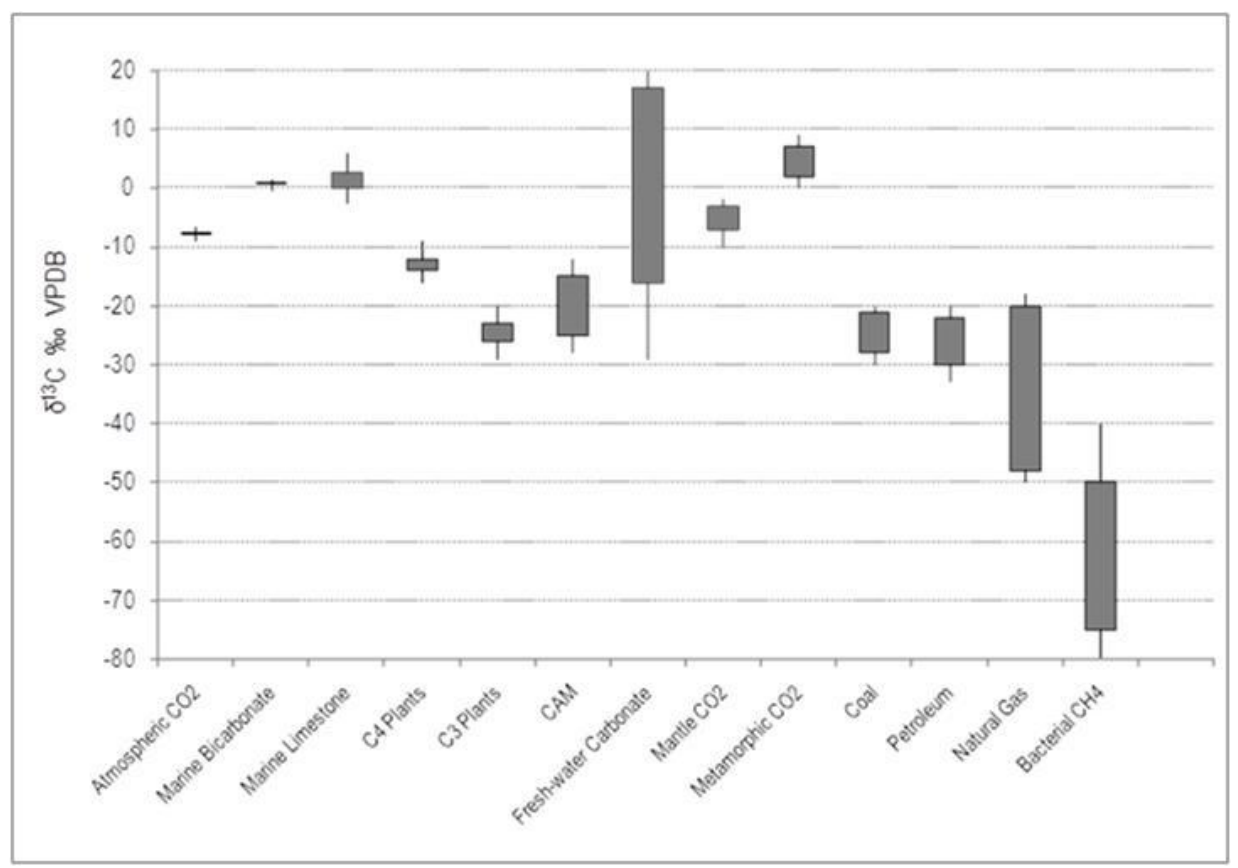

Figure 2.0-Natural variations in $\delta^{13} C$ in a range of compounds. Values show a wide range from -75 to $+20 \%$ (modified from Clark and Fritz, 1997; Mook, 2001).

The atmospheric $\mathrm{CO}_{2}$ has an average $\delta^{13} \mathrm{C}$ value of $\sim-8.0 \%$, but changes slightly with latitude and seasons (Mook and Tan, 1991). Plant carbon becomes more depleted in ${ }^{13} \mathrm{C}$ than atmospheric $\mathrm{CO}_{2}$ due to fractionation associated with $\mathrm{CO}_{2}$ diffusion and $\mathrm{CO}_{2}$ fixation. The amount of depletion depends on the photosynthetic pathway by which the plant undergoes. For example, C3 plants have an average $\delta^{13} \mathrm{C}$ value of $\sim-26 \%$ (Park and Epstein, 1961) while C4 plants have an average $\delta^{13} \mathrm{C}$ value -14 \%o (Mook and Tan, 1991). In $\mathrm{C} 3$ plants, $\mathrm{CO}_{2}$ is reacted with ribulose biphosphate (RuBP) by the enzyme ribulose biphosphate carboxylase/oxygenase ( $\mathrm{RuBisCO})$. RuBisCO preferentially fixes ${ }^{12} \mathrm{CO}_{2}$ over ${ }^{13} \mathrm{CO}_{2}$, resulting in isotope fractionation during carboxylation. $\mathrm{C} 4$ plants follow a different pathway in which $\mathrm{CO}_{2}$ is first incorporated through the carboxylation of phosphoenolpyruvate (PEP) by the enzyme phosphoenol-pyruvate carboxylase (PEP 
carboxylase). PEP carboxylase is a more efficient enzyme than $\mathrm{RuBisCO}$ and does not discriminate as much, thus $\mathrm{C} 4$ plants are more enriched in ${ }^{13} \mathrm{C}$ than $\mathrm{C} 3$ plants (O'Leary, 1981).

The $\delta^{13} \mathrm{C}$ of bicarbonate in seawater has a value of $\sim+1$ to $+1.5 \%$ and is explained by the equilibrium fractionation between atmospheric $\mathrm{CO}_{2}$ and bicarbonate at 15 to $20{ }^{\circ} \mathrm{C}$. The resulting calcite precipitating in equilibrium with oceanic bicarbonate should therefore have $\delta^{13} \mathrm{C}$ value of +2 to $+2.5 \%$ according to the well-defined fractionation between calcite and bicarbonate (Table 2.0). For example, at $25{ }^{\circ} \mathrm{C}$, the equilibrium fractionation between $\mathrm{CO}_{2(\mathrm{aq})}$ and $\mathrm{CO}_{2(\mathrm{~g})}$ is $-1.1 \%$, therefore the aqueous species will be $1.1 \%$ lighter than the gaseous species.

\begin{tabular}{|c|c|c|c|c|c|}
\hline $\mathbf{T}\left({ }^{\circ} \mathbf{C}\right)$ & $\boldsymbol{\varepsilon}^{\mathbf{1 3}} \mathbf{C}_{\mathbf{C O 2 ( a q )}-\mathbf{C O 2}(\mathrm{g})}$ & $\boldsymbol{\varepsilon}^{\mathbf{1 3}} \mathbf{C}_{\mathbf{H C O 3 - C O 2 ( g )}}$ & $\boldsymbol{\varepsilon}^{\mathbf{1 3}} \mathbf{C}_{\mathbf{C O 3 - C O 2 ( g )}}$ & $\boldsymbol{\varepsilon}^{\mathbf{1 3}} \mathbf{C}_{\mathbf{C a C O 3 - C O 2}}$ & $\boldsymbol{\varepsilon}^{\mathbf{1 3}} \mathbf{C}_{\mathbf{C a C O 3 - H C O 3}}$ \\
\hline 0 & -1.2 & 10.9 & 11.35 & 14.4 & 3.6 \\
\hline 10 & -1.1 & 9.6 & 9.2 & 12.7 & 3 \\
\hline 15 & -1.1 & 9 & 8.6 & 11.8 & 2.8 \\
\hline 20 & -1.1 & 8.5 & 8.1 & 11.1 & 2.6 \\
\hline 25 & -1.1 & 7.9 & 7.6 & 10.4 & 2.4 \\
\hline 50 & -1 & 5.5 & 5.2 & 7.4 & 1.9 \\
\hline
\end{tabular}

Table 2.0-Temperature dependent fractionation of ${ }^{13} \mathrm{C}$ in $\mathrm{CO}_{2}$-DIC reaction (modified from Clark and Fritz, 1997).

The DIC constitutes a large fraction of the carbon pool in natural waters. Analysis of DIC and the stable isotope ratio of DIC $\left(\delta^{13} \mathrm{C}_{\text {DIC }}\right)$ have been applied extensively in natural and polluted streams to identify sources and to investigate inorganic carbon dynamics (Mook and Tan, 1991; Fonyuy and Atekwana, 2008; Finlay, 2003; Brunet et al., 2005; Aravena et al., 1992; Palmer et. al., 2001; Atekwana and Richardson, 2004; Helling et al., 2001; Sharma and Baggett, 2011; Sharma and Frost, 2008). 
When $\mathrm{CO}_{2(\mathrm{~g})}$ diffuses into water, it forms four main species of DIC: dissolved or aqueous $\mathrm{CO}_{2}$, carbonic acid or hydrated $\mathrm{CO}_{2}\left(\mathrm{H}_{2} \mathrm{CO}_{3}\right)$, bicarbonate or dissociated carbonic acid $\left(\mathrm{HCO}_{3}{ }^{-}\right)$and carbonate or the second dissociation species of carbonic acid

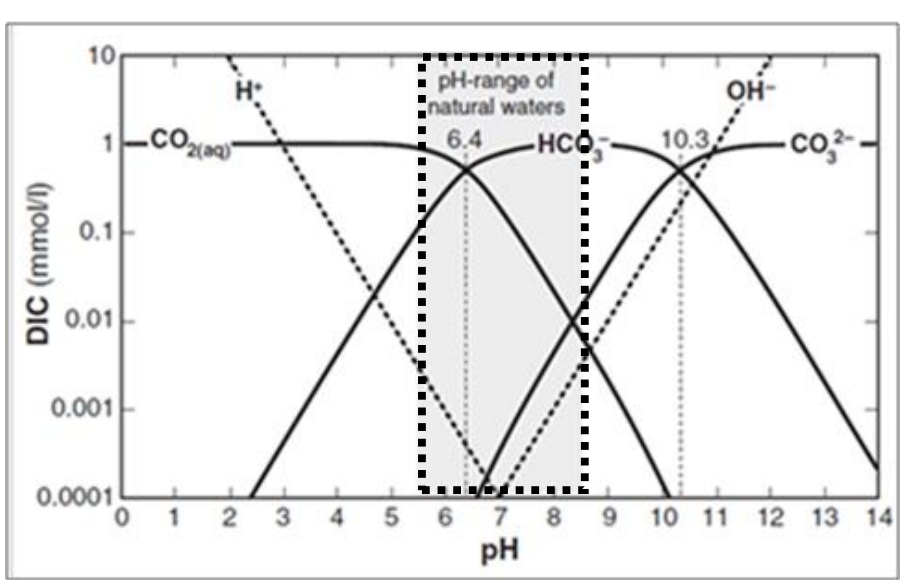

Figure 2.1-Distribution of carbonate species in pure water as a function of $\mathrm{pH}$ at $25^{\circ} \mathrm{C}$ (modified from Schulte et al., 2011). $\left(\mathrm{CO}_{3}{ }^{2-}\right) . \quad \mathrm{A}$ majority of the dissolved $\mathrm{CO}_{2}$ is in the form of solvated $\mathrm{CO}_{2}\left(\mathrm{CO}_{2(\mathrm{aq})}\right)$ rather than $\mathrm{H}_{2} \mathrm{CO}_{3}$ (Drever, 1997). Their distribution and relative concentrations are a function of $\mathrm{pH}$ (Fig. 2.1).

Dissolution of $\mathrm{CO}_{2}(\mathrm{~g})$ in water takes place according to the following reactions which each have an isotopic fractionation associated with each step (Clark and Fritz, 1997):

$\mathrm{CO}_{2}$ diffusion into water:

$\mathrm{CO}_{2}$ hydration:

$1^{\text {st }}$ dissociation of carbonic acid:

$2^{\text {nd }}$ dissociation of carbonic acid:

$$
\begin{aligned}
& \mathrm{CO}_{2(\mathrm{~g})} \leftrightarrow \mathrm{CO}_{2 \text { (aq) }} \\
& \mathrm{CO}_{2 \text { (aq) }}+\mathrm{H}_{2} \mathrm{O} \leftrightarrow \mathrm{H}_{2} \mathrm{CO}_{3}
\end{aligned}
$$$$
\mathrm{H}_{2} \mathrm{CO}_{3} * \leftrightarrow \mathrm{H}^{+}+\mathrm{HCO}_{3}^{-}
$$$$
\mathrm{HCO}_{3}{ }^{-} \leftrightarrow \mathrm{H}++\mathrm{CO}_{3}^{2-}
$$

The sum of these species makes up the total DIC in water:

$$
\mathrm{CO}_{2(\mathrm{aq})}+\mathrm{H}_{2} \mathrm{CO}_{3}{ }^{*}+\mathrm{HCO}_{3}{ }^{-}+\mathrm{CO}_{3}{ }^{2-}=\mathrm{DIC}
$$


The fractionation factors under equilibrium conditions are temperature-dependent and the carbon isotope signature of different carbonate species can be predicted using these well-defined relationships (Table 2.0).

The carbon isotope composition of DIC in freshwater is ultimately controlled by the sources of carbon to the system as well as the isotopic fractionation involved between the solid, dissolved and gaseous phases (Mook and Tan, 1991). Groundwaters infiltrate through the soil which dissolves and hydrates soil $\mathrm{CO}_{2(\mathrm{~g})}$. The infiltrating $\mathrm{CO}_{2(\mathrm{aq})}$ is then able to dissolve calcite and produce bicarbonate by the following equation:

$$
\mathrm{CaCO}_{3}+\mathrm{H}_{2} \mathrm{CO}_{3} \rightarrow \mathrm{Ca}^{2+}+2 \mathrm{HCO}_{3}^{-}
$$

Bicarbonate produced from the dissolution of calcite defines one of the major sources of DIC in natural waters. Dissolution of carbonates consumes acidity, resulting in $\mathrm{a}$ rise in $\mathrm{pH}$ and the redistribution of DIC species. At a $\mathrm{pH}$ less than $6.4, \mathrm{CO}_{2(\text { aq) }}$ is the dominant species and the major fractionation processes is the gas-aq $\mathrm{CO}_{2}$, which imparts a fractionation factor of $1.1 \%$. Values of $\delta^{13} \mathrm{C}_{\mathrm{DIC}}$ at these conditions will be depleted (-24 to -22 \%) since the total DIC will

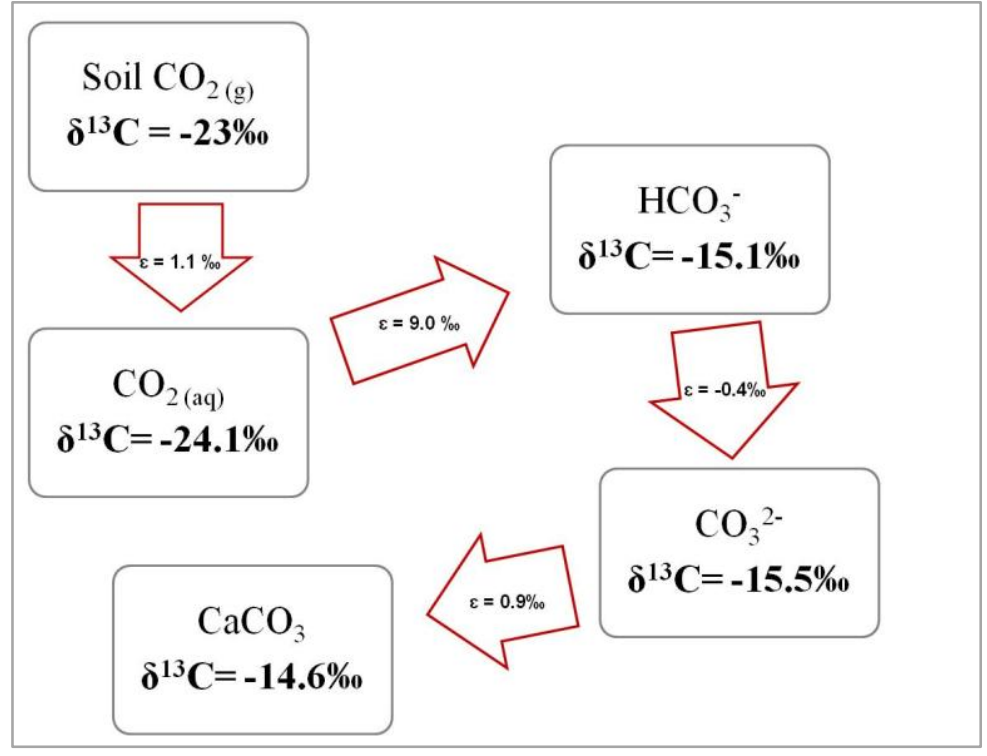

Figure 2.2-Fractionation of ${ }^{13} \mathrm{C}$ during equilibrium exchange of carbon between the different species at $25^{\circ} \mathrm{C}$ (modified from Clark and Fritz. 1997). 
be primarily composed of $\mathrm{CO}_{2(\mathrm{aq})}$, which is the lightest component of the DIC. At a $\mathrm{pH}$ between 6.4 and 10.3, bicarbonate $\left(\mathrm{HCO}_{3}{ }^{-}\right)$will be the dominant species (Fig. 2.1). The dominant fractionation process at these conditions is between $\mathrm{CO}_{2(\mathrm{aq})}-\mathrm{HCO}_{3}{ }^{-}$which results in a $9 \%$ enrichment above $\mathrm{CO}_{2(\mathrm{aq})}$, and thus a higher $\delta^{13} \mathrm{C}_{\mathrm{DIC}}$ signature compared to $\mathrm{CO}_{2}$ source (Fig. 2.2).

Ambient groundwaters have an average carbon isotope composition of -11 to -16 \%. This is a result of the contribution of different end-members to the total dissolved inorganic carbon in the system. One end member is soil $\mathrm{CO}_{2}$ which has an average $\delta^{13} \mathrm{C} \approx$ $-26 \%$ in $\mathrm{C} 3$ vegetation dominated areas like the study area. Soil $\mathrm{CO}_{2}$ is a product of root respiration and oxidation of organic matter. The isotopic signature of soil $\mathrm{CO}_{2}$ is a function of the source and the fractionation involved in the process of $\mathrm{CO}_{2}$ diffusion. The process of $\mathrm{CO}_{2}$ diffusion into the plant enriches the soil $\mathrm{CO}_{2}$ by $\sim 4.4 \%$ in $\mathrm{C} 3$ plants relative to the source (Aravena et al., 1992). The other major end-member contributing to the total DIC is much more positive $\left(\delta^{13} \mathrm{C} \approx+1 \%\right.$ ) and is derived from carbonate rock dissolution (Fig. 2.0). The extent by which dissolution occurs is a function of the concentration of soil $\mathrm{CO}_{2}$ and the mineralogy of the sediment (Aravena et al., 1992). Although these values are representative of typical groundwater systems, literature values of $\delta^{13} \mathrm{C}_{\mathrm{DIC}}$ values in the range of +10 to $+30 \%$ in organic rich systems where bacterial processes, such as methanogenesis, preferentially remove the lighter carbon $\left({ }^{12} \mathrm{C}\right)$ and add back ${ }^{13} \mathrm{C}$-enriched $\mathrm{CO}_{2}$ to the DIC pool (Whiticar et. al, 1986; Simpkins et. al, 1993; Cheung et al., 2010; Laughrey and Baldassare, 1998; Börjesson et al, 1997; Sharma and Frost, 2008; Atekwana, 1996). Additionally, groundwaters in thickly-vegetated drainage basins with low carbonate content in the soils have reported values as negative as $-28 \%$. 
This extremely negative signature was attributed to large amounts of biogenic soil $\mathrm{CO}_{2}$ with low $\delta^{13} \mathrm{C}$ (Mook and Tan, 1991).

The interaction between groundwater and organic matter has an important effect on the carbon isotope composition of the dissolved inorganic carbon in groundwater. Kinetic processes such as oxidation of organic matter and microbial processes change the chemical composition and oxidation state of dissolved constituents, which is then accompanied by large shifts in isotopic signatures. There are two main processes which organic matter can be oxidized in the soil environment, either by dissolved oxygen in groundwater or by dissolved sulfate, discussed further in the sulfate isotopes section. Organic carbon oxidation by dissolved oxygen proceeds by the following reaction:

$$
\mathrm{CH}_{2} \mathrm{O}+\mathrm{O}_{2} \leftrightarrow \mathrm{CO}_{2}+\mathrm{H}_{2} \mathrm{O}
$$

The resulting $\mathrm{CO}_{2}$ (added to the total DIC) will be isotopically-depleted in ${ }^{13} \mathrm{C}$ since the typical $\delta^{13} \mathrm{C}$ value of soil/aquifer-derived organic carbon is $\sim-26 \%$. Furthermore, the produced $\mathrm{CO}_{2}$ has the potential to dissolve carbonates which would increase the concentration of DIC.

A second process involving chemical interactions between organic matter and groundwater is methanogenesis. In groundwater, methane can originate as biogenic methane, thermogenic methane, or mantle methane. Biogenic methane, being the most common form in shallow groundwaters, is produced as a byproduct of bacterial reduction of organic carbon by two major pathways; $\mathrm{CO}_{2}$ reduction and acetate fermentation. In both cases, the ${ }^{13} \mathrm{C}$ fractionation between $\mathrm{CO}_{2}$ and $\mathrm{CH}_{4}$ is very large $(\sim 75 \pm 15 \%$ ) with the methanogenic bacteria favoring the lighter isotopes. This mechanism results in $\delta^{13} \mathrm{C}$ 
values depleted from original $\mathrm{CO}_{2}$ by 50 to $80 \%$ (Whiticar et al., 1986). Additionally, the discrimination by bacteria for the lighter carbon will result in the residual carbon pool (i.e. DIC) becoming enriched in ${ }^{13} \mathrm{C}$. Therefore, the $\delta^{13} \mathrm{C}_{\mathrm{DIC}}$ is useful as an indicator of methanogenesis in groundwater systems.

Thermogenic methane is formed from the breakdown of higher hydrocarbons at depth with high temperatures and pressures. Thermogenic methane is usually enriched in ${ }^{13} \mathrm{C}$ relative to biogenic methane due to differences in parent material and kinetic fractionations. A majority of methane studies focus on determining the source of methane as either biogenic or thermogenic to determine sources of groundwater contamination or evidence of natural gas presence for production (Atekwana, 1996; Börjesson et al., 2007; Cheung et al., 2010; Laughrey et al., 1998; Osborn et al., 2011; Sharma and Frost, 2008; Zhang and Krooss, 2001).

For the reasons described above, stable isotopes of carbon are useful indicators of carbonate evolution and carbon cycling in groundwaters. This information is applicable when studying water quality, fate of contaminants and water-rock interactions in the subsurface.

\subsubsection{Oxygen and hydrogen isotopes}

Early work on isotopes in the 1960 s studied in great detail ${ }^{18} \mathrm{O} /{ }^{16} \mathrm{O}$ variations in global precipitation in addition to meteorological patterns. Stable isotopes of water $\left({ }^{18} \mathrm{O}\right.$ and ${ }^{2} \mathrm{H}$ ) are affected by meteorological processes impart a specific isotopic fingerprint, characteristic of their origin. A precipitation sampling network was established by the International Atomic Energy Agency (IAEA) in cooperation with World Meteorological Organization (WMO) known as the Global Network of Isotopes in Precipitation (GNIP). 


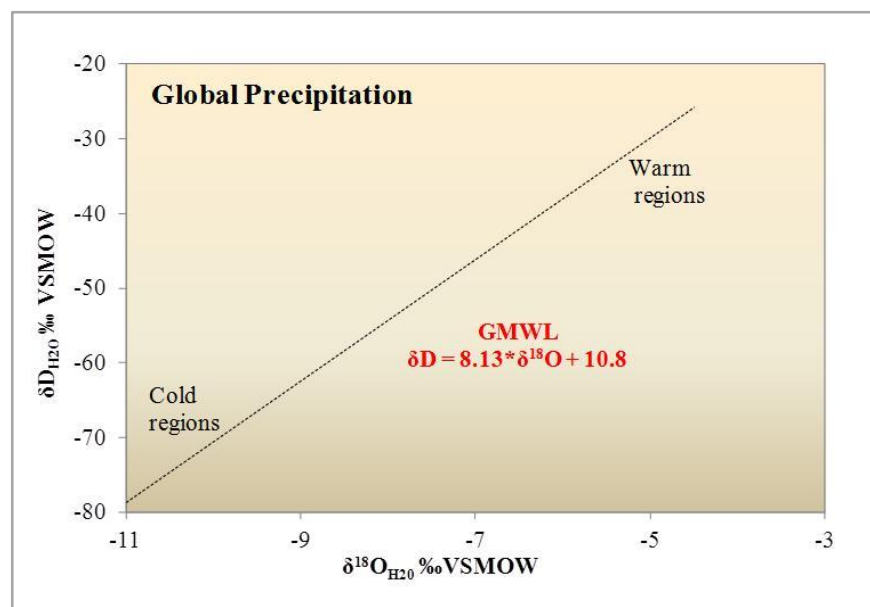

Figure 2.3-Global relationship for ${ }^{18} \mathrm{O}$ and ${ }^{2} \mathrm{H}$ from precipitation samples. Data compiled from the IAEA global network (modified from Clark and Fritz, 1997).
They were responsible for the collection of monthly precipitation data at about 100 sampling sites world-wide. Samples were analyzed for ${ }^{18} \mathrm{O},{ }^{2} \mathrm{H}$ and ${ }^{3} \mathrm{H}$ content and results were evaluated by Dansgaard (1964), Yurtsever (1975), and Rozanski et al. (1993). Following initial isotopic studies on ${ }^{2} \mathrm{H}$ and and $\delta^{2} \mathrm{H}$ in freshwaters on a global scale. His findings suggested that ${ }^{18} \mathrm{O}$ and ${ }^{2} \mathrm{H}$ behaved in a predictable fashion and later defined this relationship as the "global meteoric water line" with the equation: $\delta^{2} \mathrm{H}=8 * \delta^{18} \mathrm{O}+10 \%$ VSMOW (Fig. 2.3). This relationship is defined by the average of many local meteoric

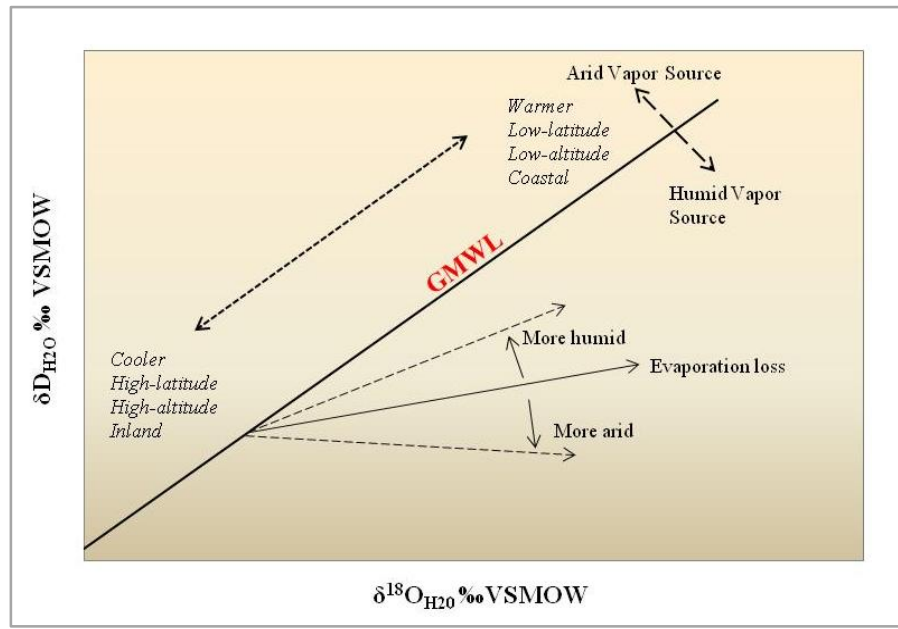

Figure 2.4-Deviations from the GMWL as a result of different hydrological processes and origins of airmass in different climatic and (modified from SAHRA). geographic regions.

Meteoric waters are mostly depleted in the heavy isotopes compared to oceanic waters. The isotopic composition of modern seawater, which is accepted as the global 
standard, is equal to $0 \%$. Deviation from this value is a result of various processes in the global water cycle. The evolution of $\delta^{18} \mathrm{O}$ and $\delta^{2} \mathrm{H}$ begins with evaporation from the sea, followed by precipitation over the oceans as the vapor mass moves to higher latitudes and altitudes where the vapor mass cools and condenses. This processes, known as Rayleigh distillation, indicates that the further removed the water source, the more depleted the meteoric waters are in heavy isotopes. Dansgaard (1964) described effects known as the altitude, latitude and continental effects which are all related to the depletion of heavy isotopes by a rainout process as an airmass is cooled. Thus, temperature is the key factor which controls the isotopic composition of rainwater since varying temperatures dictates the amount of moisture a cloud mass can hold (Frick and O'Neil, 1999; Rosanski et. al, 1993; Kendall and Coplen, 2001). Extreme cases are seen at the poles where values for $\delta^{18} \mathrm{O}$ were reported as depleted as $-50 \%$ (Epstein and Sharp, 1965) while in warmer climates values tend to be more enriched in the heavy isotopes. Departure from the GMWL is a consequence of different hydrologic processes and conditions (Fig. 2.4). Variations of $\delta^{18} \mathrm{O}$ and $\delta^{2} \mathrm{H}$ signatures in different waters and materials are summarized in Figures 2.5 and 2.6. Note the range in meteoric waters. 


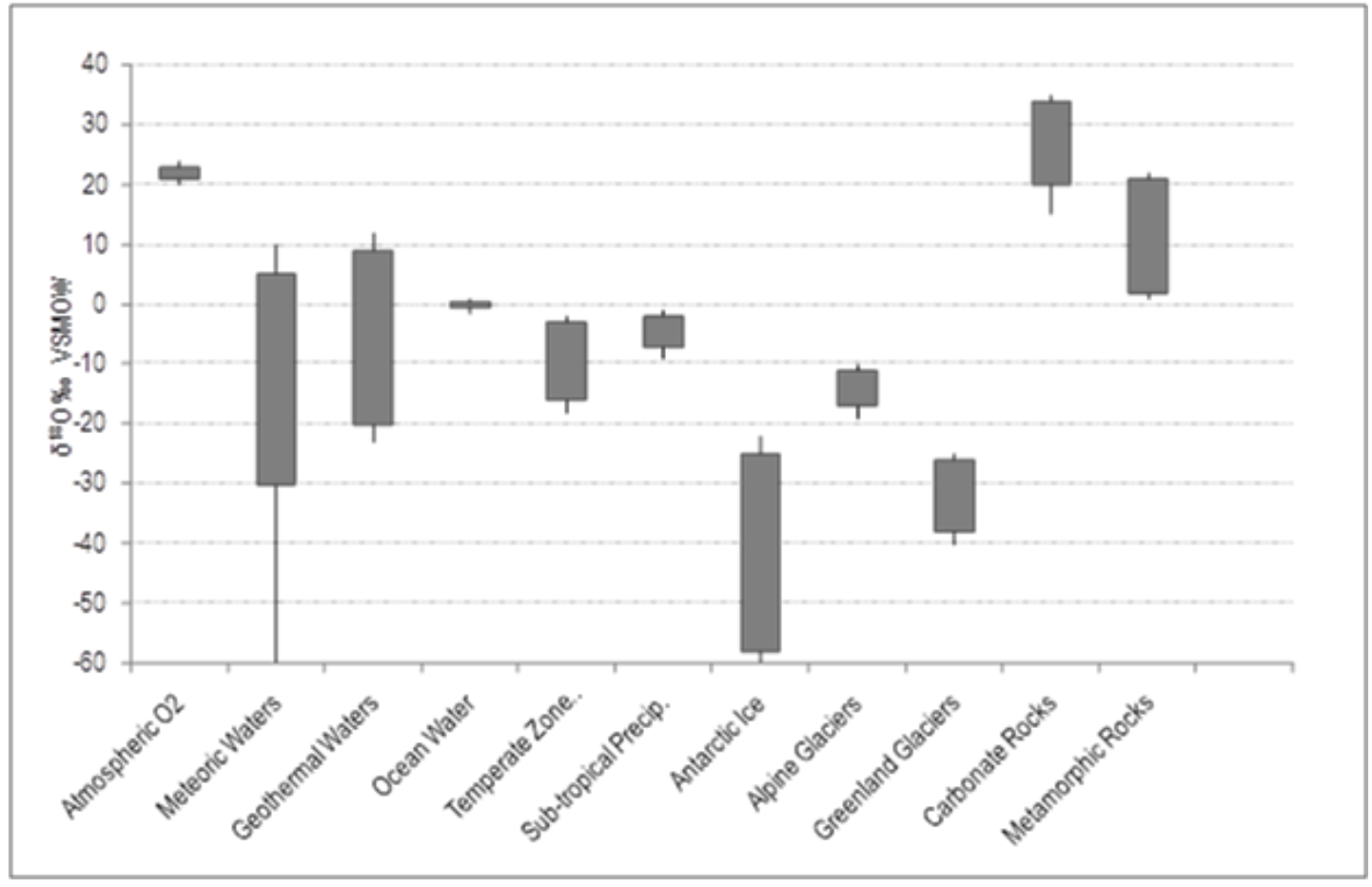

Figure 2.5-Natural variations in $\delta^{18} \mathrm{O}$ in a range of waters and compounds. Values show a wide range from -60 to +35\%o (modified from Clark and Fritz, 1997; Mook, 2001).

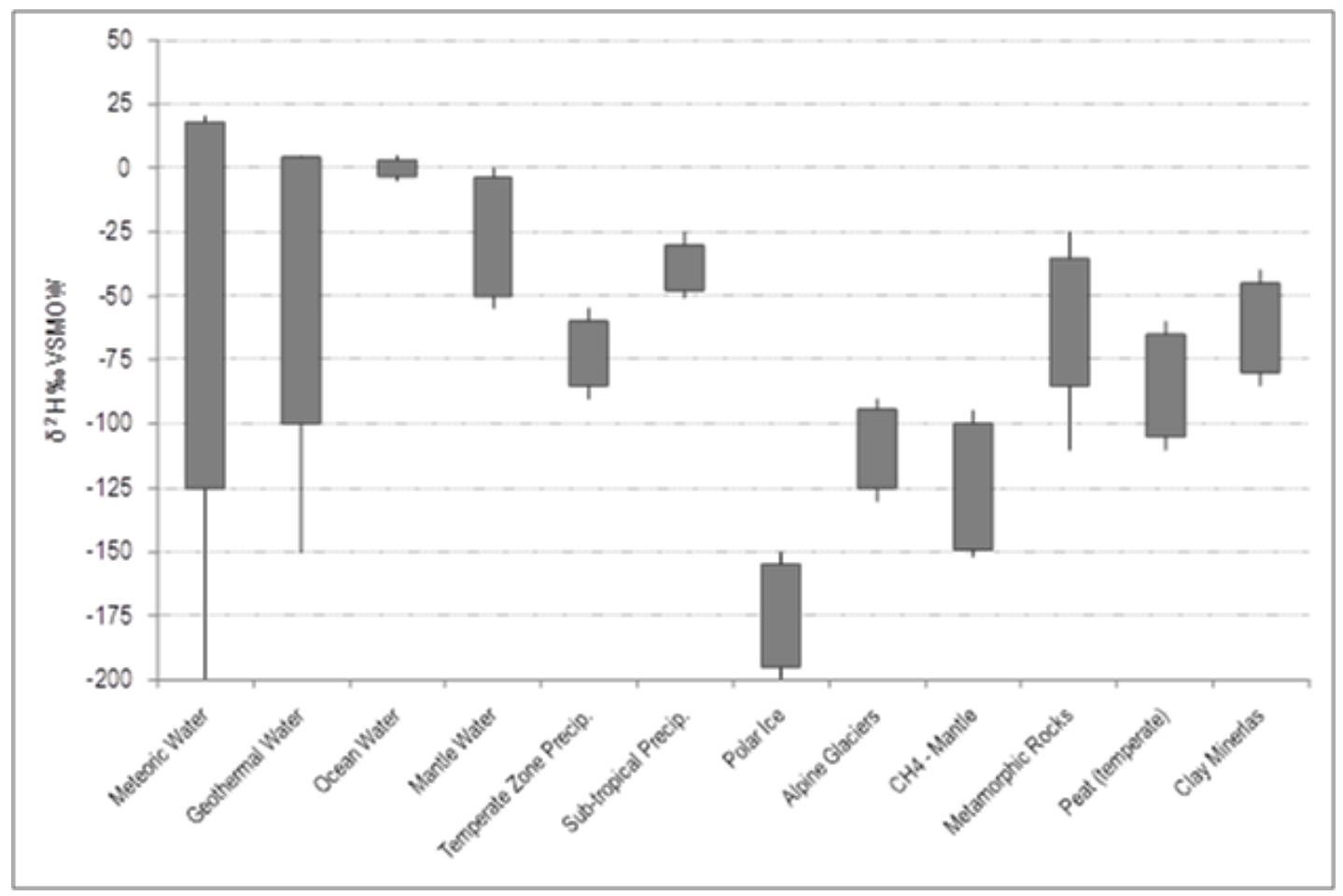

Figure 2.6-Natural variations in $\delta^{2} H$ in a range of waters and compounds. Values show a wide range from -200 to +25\%o (modified from Clark and Fritz, 1997; Mook, 2001). 
The $\delta^{18} \mathrm{O}$ and $\delta^{2} \mathrm{H}$ signatures of water are important in determining different groundwater sources and recharge since in many situations groundwater is controlled by meteorological processes. Determining the origin of groundwaters is particularly important for providing information needed for sustainable groundwater management and protection (Geyh, 2001). In addition to sourcing water, stable isotopes of water provide information on the movement of groundwater and its dissolved components, and allow for a quantitative analysis of mixing and recharge. Various reactions between groundwater and surrounding rock matrix have also been studied, since at extreme conditions, the isotopic signature of meteoric waters can be altered. Rock-water interaction processes such has hydration of silicates, exchange with $\mathrm{CO}_{2}$, high

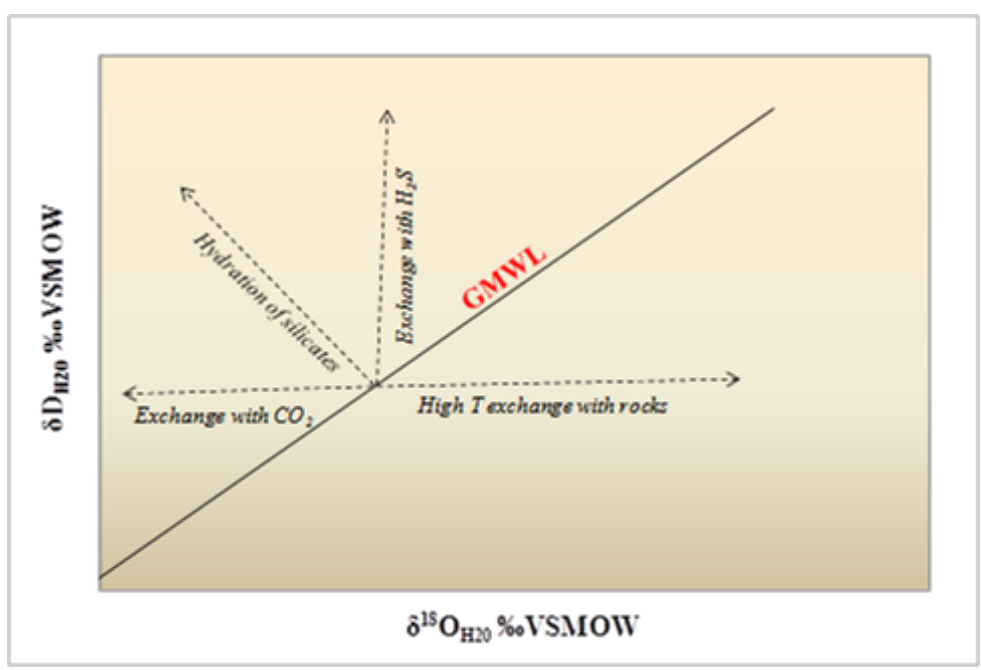

Figure 2.7-Exchange processes involving water-rock interaction which alter the isotopic composition of meteoric waters (modified from Clark and Fritz, 1997). temperature exchange with rocks, and exchange with $\mathrm{H}_{2} \mathrm{~S}$ are all examples in which the $\delta^{18} \mathrm{O}$ and $\delta^{2} \mathrm{H}$ signature of meteoric waters can be modified (Fig. 2.7). Examples of studies which have used stable isotopes of water to understand variations in isotopic signatures due to different recharge sources, exchange reactions and rock-water interactions include Blasch and Bryson (2007), Hunt et al. (2005), Gat et al. (1996), Frick and O’Neil (1999), Rosanski et.al (1993), Mutlu (2007), Qin et al. (2005), McColloch et al. (1974) and Kumar et al. (2011). 
The isotopic and chemical compositions of groundwater reflect the composition of the rock matrix it is in contact with. Therefore, their isotope compositions can be used to determine recharge areas as well as the origin of groundwater. Isotopic exchange between groundwater and minerals at near surface conditions (low temperatures) is slow (Geyh, 2001). As a result of the slow exchange of hydrogen and oxygen between cold groundwater and the surrounding rock matrix, groundwater of different origin can preserve their isotopic signature over geologic time scales (Clark and Fritz, 1997).

\subsubsection{Sulfur and oxygen isotopes of dissolved sulfate}

Sulfur compounds in the environment are useful proxies for determining sources of water and sulfates. The isotopic composition of sulfur and oxygen, expressed as

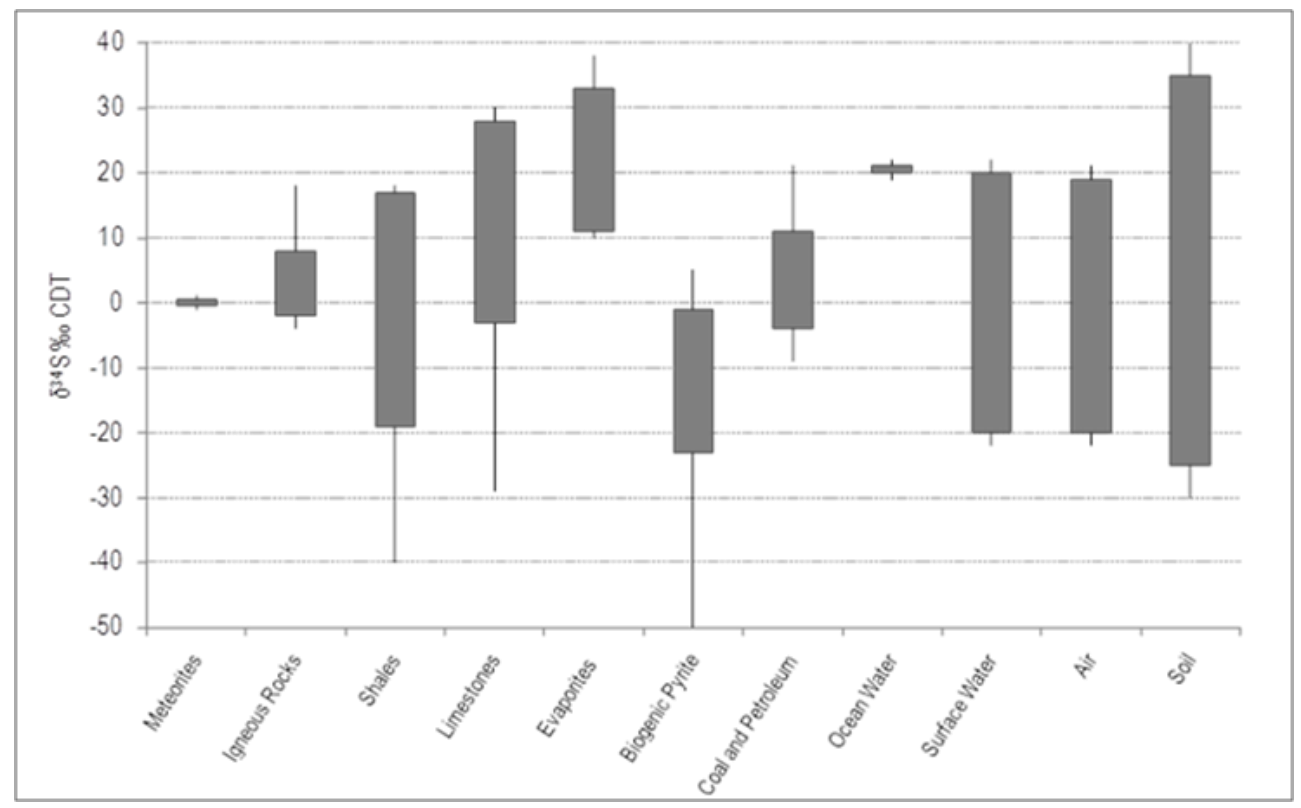

Figure 2.8-Natural variations in $\delta^{34} S$ in a range of compounds. Values show a wide range from -25 to +35\%o (modified from Clark and Fritz, 1997; Mook, 2001; Krouse, 1980).

$\delta^{34} \mathrm{~S}_{\mathrm{SO}}$ VCDT and $\delta^{18} \mathrm{O}_{\mathrm{SO} 4}$ VSMOW, are strongly affected by microbial activity and water-rock interactions. The ranges for $\delta^{34} \mathrm{~S}$ in nature are summarized in Figure 2.8. 
Values of $\delta^{34} \mathrm{~S}$ range from -50 to $+40 \%$ VCDT due to the various oxidation states and sources of sulfur. There are three main reservoirs of sulfur; evaporite sulfate with highlyenriched values (+10 to $+30 \%$ ), dissolved sulfate in ocean water $(+21 \%)$ and sedimentary sulfides with more depleted values around -12 \%o (Geyh, 2001).

In groundwaters, the isotopic composition is controlled by three main factors: the composition of the source of sulfate, isotope exchange reactions, and kinetic effects during transformation reactions (Krouse and Mayer, 2000). These geochemical pathways impart fractionations through dissolution/precipitation of sulfate minerals, sulfate reduction, sulfide oxidation, and exchange reactions of isotopes (Fig. 2.9) (Krouse et al., 1991; Clark and Fritz, 1997).

Isotope exchange

reactions for sulfur and oxygen

have an effect on the isotopic

composition of sulfate, but

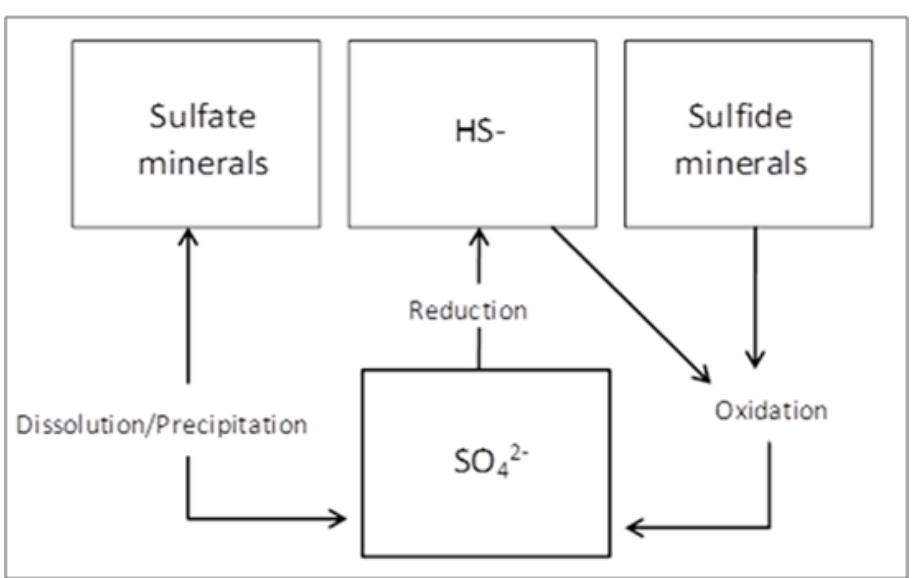

Figure 2.9-Different geochemical pathways which result in sulfur isotope fractionation. Note the largest fractionation occurs during sulfate reduction since sulfate-reducing bacterial preferentially remove the lighter isotopes of dissolved sulfate $\left({ }^{32} \mathrm{~S}\right.$ and $\left.{ }^{16} \mathrm{O}\right)$, leaving the residual sulfate enriched in the heavy isotopes $\left({ }^{34} \mathrm{~S}\right.$ and $\left.{ }^{18} \mathrm{O}\right)$.

these reactions occur at a very

slow rate and at extreme conditions in order to obtain enough activation energy to proceed.

An example exchange reaction is shown below where sulfur and oxygen isotopes can exchange between species:

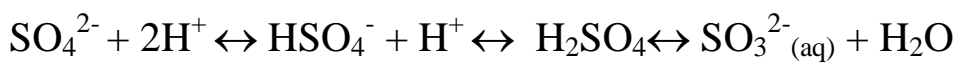


Biological and geochemical reactions are important as they impart a large kinetic fractionation on the $\mathrm{S}$ and $\mathrm{O}$ isotope composition of dissolved sulfate. Major fractionation processes include formation of evaporites, microbial reduction, and oxidation of sulfide minerals. For sulfur isotopes the largest fractionation occurs during microbial reduction of dissolved sulfate to reduced sulfides, described by the following equations (Seal et al., 2000; Clark and Fritz, 1997):

$$
\begin{aligned}
& 2 \mathrm{CH}_{2} \mathrm{O}+\mathrm{SO}_{4}{ }^{2-} \rightarrow 2 \mathrm{HCO}_{3}^{-}+\mathrm{H}_{2} \mathrm{~S} \quad \text { (oxidation of fixed carbon) } \\
& \mathrm{CH}_{4}+\mathrm{SO}_{4}{ }^{2-} \rightarrow \mathrm{HCO}_{3}{ }^{-}+\mathrm{HS}^{-}+\mathrm{H}_{2} \mathrm{O} \text { (oxidation of reduced carbon) [Eq. 2.11] }
\end{aligned}
$$

where bacteria such as Desulfovibrio desulfuricans use sulfate as an electron acceptor and produce reduced sulfide and bicarbonate species. The sulfate-reducing bacteria more readily metabolize ${ }^{32} \mathrm{~S}$ relative to ${ }^{34} \mathrm{~S}$, thus leaving the residual sulfate enriched in ${ }^{34} \mathrm{~S}$ (Eqs. 2.10 and 2.11).

The oxidation of sulfide minerals is another important process when determining sources of sulfate in groundwaters (Eqs. 2.12 and 2.13) (Van Everdingen and Krouse, 1985; Van Stempvoort and Krouse, 1994; Seal et al, 2000; Taylor and Wheeler, 1994). The reactions below describe the oxidation of pyrite, with the latter being the rate limiting reaction, generally accelerated in the presence of Thiobacillus ferrooxidans which are iron-oxidizing bacterium and dominating at low $\mathrm{pH}$ (Taylor and Wheeler, 1994):

$$
\begin{aligned}
& \mathrm{FeS}_{2}+3.5 \mathrm{O}_{2}+\mathrm{H}_{2} \mathrm{O} \rightarrow \mathrm{Fe}^{2+}+2 \mathrm{SO}_{4}{ }^{2-}+2 \mathrm{H}^{+} \\
& \mathrm{FeS}_{2}+14 \mathrm{Fe}^{3+}+8 \mathrm{H}_{2} \mathrm{O} \rightarrow 15 \mathrm{Fe}^{2+}+2 \mathrm{SO}_{4}{ }^{2-}+16 \mathrm{H}^{+}
\end{aligned}
$$


Unlike microbial reduction reactions, oxidation reactions will generally result in depleted sulfur in the residual sulfate since pyrite is a depleted source of sulfur (Fig. 2.8). The oxidative weathering of pyrite to form dissolved sulfate produces negligible sulfur isotope fractionation, in contrast to the oxygen isotope composition of the produced sulfate (Seal, 2003; Seal, 2006).

The dissolution and precipitation of major evaporite minerals, such as gypsum and anhydrite also provide insight about the sources of sulfate. Gypsum has a relatively low solubility in water and its dissolution is described by the following equation:

$$
\mathrm{CaSO}_{4} \cdot 2 \mathrm{H}_{2} \mathrm{O} \rightarrow \mathrm{Ca}^{2+}+\mathrm{SO}_{4}{ }^{2-}+2 \mathrm{H}_{2} \mathrm{O}
$$

Though the isotopic composition of sulfate is not affected by dissolution of evaporite minerals, the crystallization of sulfate minerals tends to favor the heavier isotopes. This is because the heavier isotopes preferentially accumulate in the denser phase. The $\delta^{34} \mathrm{~S}_{\mathrm{SO} 4}$ and $\delta^{18} \mathrm{O}_{\mathrm{SO} 4}$ have been measured to be 1.7 to $3.6 \%$ higher than the dissolved sulfate in which they formed (Krouse and Mayer, 2000). Sulfate concentrations in water can be used in conjunction with the isotopic signature to better understand common mineral processes. Sulfate in groundwater would be expected to increase proportionally (1:1 ratio) to calcium if gypsum dissolution was the only source. An important exception to note is that as a result of the common ion effect where dissolution of gypsum forces calcite precipitation which would result in a disproportionate increase in sulfate concentrations by the following reaction:

$$
\mathrm{Ca}^{2+}+\mathrm{HCO}_{3^{-}}+\mathrm{CaSO}_{4} \cdot 2 \mathrm{H}_{2} \mathrm{O} \rightarrow \mathrm{Ca}^{2+}+\mathrm{SO}_{4}{ }^{2-}+\mathrm{CaCO}_{3}+\mathrm{H}^{+}+\mathrm{H}_{2} \mathrm{O}
$$


The isotopic composition of oxygen in sulfate $\left(\delta^{18} \mathrm{O}_{\mathrm{SO} 4}\right)$ is more complicated to interpret, as both oxygen in the atmosphere and water can contribute to its formation. In an aqueous system, the rate of oxygen isotopic exchange between $\mathrm{H}_{2} \mathrm{O}$ and $\mathrm{SO}_{4}{ }^{2-}$ is extremely slow at surface conditions; however the exchange rate of oxygen between $\mathrm{H}_{2} \mathrm{O}$ and $\mathrm{SO}_{3}$ is much higher (Eq. 2.9). As a result, the $\delta^{18} \mathrm{O}_{\mathrm{SO} 4}$ is comprised mainly ( $\left.75 \%\right)$ of ${ }^{18} \mathrm{O}_{\mathrm{H} 2 \mathrm{O}}$ which has values ranging from $\sim 0$ to $-55 \%$. Atmospheric oxygen, which is the other contributor to oxygen in sulfate, has a much more positive value of $+23.5 \%$ (Krouse and Mayer, 2000). The $\delta^{18} \mathrm{O}_{\mathrm{SO} 4}$ varies depending on the isotopic composition of the oxygen in the water and air, as well as the oxidizing agent in the case of pyrite oxidation (i.e. $\mathrm{O}_{2}$ or $\mathrm{Fe}^{3+}$ ) (Eqs. 2.12 and 2.13). Additionally, enrichment in ${ }^{18} \mathrm{O}$ can result from oxidation of intermediate sulfoxyanions during the formation of aqueous sulfate (Seal, 2006; Van Everdingen and Krouse, 1985). The oxidation of sulfoxyanions can occur quickly and the resulting sulfate may acquire oxygen via exchange with $\mathrm{H}_{2} \mathrm{O}$. For example, the oxidation of dissolved sulfite $\left(\mathrm{SO}_{3}{ }^{2-}\right)$ is often a precursor to the formation of aqueous sulfate. Other sulfur oxyanions include thiosulfate $\left(\mathrm{S}_{2} \mathrm{O}_{3}{ }^{2-}\right)$ and polythionate $\left(\mathrm{S}_{\mathrm{n}} \mathrm{O}_{6}{ }^{2-}\right)$ as intermediates compounds to the oxidations pathway of $\mathrm{FeS}_{2}$ to $\mathrm{SO}_{4}{ }^{2-}$. Oxidation of sulfur oxyanions is describes in the equations below (Write and Nordstrom, 1999):

$$
\begin{aligned}
& \mathrm{S}_{2}{ }^{2-}{ }_{\text {pyrite }}+\mathrm{OH}-\rightarrow \mathrm{S}_{2} \mathrm{O}_{3}{ }^{2-} \\
& \mathrm{S}_{2} \mathrm{O}_{3}{ }^{2-}+\mathrm{OH}-\rightarrow \mathrm{S}_{4} \mathrm{O}_{6}{ }^{2-} \rightarrow \mathrm{SO}_{4}{ }^{2-} \\
& \mathrm{S}_{2} \mathrm{O}_{3}{ }^{2-}+\mathrm{OH}-\rightarrow \mathrm{SO}_{4}{ }^{2-}
\end{aligned}
$$

The formation of these intermediate sulfoxyanions causes enrichment in ${ }^{18} \mathrm{O}$ with increasing oxidation state, relative to the lower oxidation state intermediates. Multiple oxidation steps are therefore required to incorporate oxygen into the sulfate molecule. As 
a result, each step may affect the final isotopic signature of the dissolved sulfate formed (Seal, 2003; Van Stempvoort and Krouse, 1994).

As explained above, sulfate in groundwater can originate from a variety of sources and its isotopic signature can be transformed by biogeochemical processes. Thus, values for $\delta^{34} \mathrm{~S}_{\mathrm{SO} 4}$ have been found to range from -30 to $>+50 \%$ and $\delta^{18} \mathrm{O}_{\mathrm{SO} 4}$ values range from -20 to $+30 \%$ in dissolved sulfate (Krouse and Mayer, 2000). Despite the several processes that can alter the isotopic composition of dissolved sulfate in waters, $\delta^{34} \mathrm{~S}_{\mathrm{SO} 4}$ and $\delta^{18} \mathrm{O}_{\mathrm{SO} 4}$ have proven to be efficient tracers/indicators of key environmental processes (Berner et al., 2002; Trembaczowki et al., 2004; Van Donkelaar et al., 1995; Seal, 2003; Van Stempvoot and Krouse, 1994). In addition, sulfate isotopes used in conjunction with $\mathrm{O}$ and $\mathrm{H}$ isotopes have been used to distinguish sources of sulfate in groundwater from different recharge sources. Plotting $\delta^{18} \mathrm{O}_{\mathrm{SO} 4}$ against $\delta^{18} \mathrm{O}_{\mathrm{H} 2 \mathrm{O}}$ can distinguish enrichment of sulfate isotopes from anthropogenic activities and bacterial reduction in addition to the origins of waters (i.e. Fouillac et al., 1990; Mutlu, 2007).

\subsection{Hydrochemistry}

Typical hydrochemical analysis have been used for monitoring water quality, investigating sources and mixing of recharge waters as well as understanding groundwater dynamics. Hydrochemistry was not the focus of this study, but a brief summary of the potential use of data is discussed. Major cations and anions, including $\mathrm{Ca}^{2+}, \mathrm{Mg}^{2+}, \mathrm{Na}^{+}, \mathrm{K}^{+}, \mathrm{SO}_{4}{ }^{2-}, \mathrm{NO}_{3}{ }^{-}, \mathrm{Cl}^{-}, \mathrm{HCO}_{3}{ }^{-}$, and $\mathrm{CO}_{3}{ }^{2-}$ are traditionally used to examine the geochemistry of waters and rock-water interactions (i.e. dissolution/precipitation processes). Different water types are generally classified based on their relative 
concentrations of major cation and anion constituents. In addition to sourcing waters and evaluating mixing, geochemical relationships between major cations and anions provide information about weathering processes and mineral dissolution/precipitation. Specific examples include calcite dissolution, which results in an increase in $\mathrm{HCO}_{3}{ }^{-}$with an increase in of $\mathrm{Ca}^{2+}$ in a 2:1 molar ratio, dolomite dissolution resulting in a 1:1 ratio of $\mathrm{Ca}^{2+}$ and $\mathrm{Mg}^{2+}$ and gypsum dissolution resulting 1:1 molar ratio of $\mathrm{Ca}^{2+}$ and $\mathrm{SO}_{4}{ }^{2-}$. Various studies have explored these relationships, including Lawrence et al. (1976), Marfia et al. (2004), Mondal et al. (2010), Panno et al. (1994), Barbieri et al. (2005) and Chae et al. (2006).

Brine chemistry can also be useful in determining sources of salinity in waters. Brines contain high concentrations of salts and can originate from oceanic water, mineral dissolution (i.e. halite) or evaporative processes. Often various elemental plots including $\mathrm{Cl}^{-}, \mathrm{Br}^{-}, \mathrm{Na}^{+}, \mathrm{Ca}^{+2}, \mathrm{Mg}^{+2}, \mathrm{~K}^{+}$, and $\mathrm{SO}_{4}{ }^{2-}$ are used to distinguish sources of salinity in a system. For example, Kesler et al. (1997) used Na-Cl-Br systematic to show that most Mississippian Valley type (MVT) brines in the Appalachians formed by evaporation of seawater in contrast to dissolution of evaporite minerals. Additionally, $\mathrm{Br}^{-} / \mathrm{Cl}^{-}$ratios and $\mathrm{Na}^{+} / \mathrm{Cl}^{-}$ratios can be compared with seawater values to determine if there is mixing of seawater in freshwater aquifers and determine where the salinity originated (Cartwright et al., 2007; Mondal et al., 2010; Kim et al., 2003). In this study, these salinity correlations may be of importance when determining sources of highly saline flowback waters and their potential to mix with shallow freshwater aquifers. Warner et al. (2012) integrated chemical data $(\mathrm{Br}, \mathrm{Cl}, \mathrm{Na}, \mathrm{Sr}$, and $\mathrm{Li}$ ) along with isotopic data to determine the possible contamination of brine to shallow drinking water aquifers in Pennsylvania. 
The different abundances of major cations and anions can consequently be useful indicators of various rock-water interaction processes as well as evidence of microbial processes. Hydrochemistry data alone may not be sufficient in some cases to determine sources of water and mixing because of their un-conservative nature. Problems with using major cations and anions as tracers include sorption by cation exchange processes and dilution/concentration in solutes from unknown sources or geochemical processes (Davis et al., 1980). Thus, these constituents will be used in conjunction with stable isotopes to further delineate biogeochemical transformations occurring within a system.

\subsection{Applications of Stable Isotopes in the Environment}

The variations in water-rock interactions recharge sources, recharge pathways, and age can impart unique isotopic signatures to different waters and its dissolved components. Hence, stable isotopes have become an important tool for determining sources and cycling of water, carbon, and other constituents (e. g. Blasch et al., 2007; Atekwana and Richardson, 2004; Brunet et al., 2005, Palmer et al., 2001; Wright and Nordstrom, 1999; Marfia et al., 2004).

\subsubsection{Natural springs}

Stable isotopes are an extremely powerful tool in natural spring systems when studying the effects of rock-water interactions on the isotopic signatures, as well as the origin of water and its solutes. Isotopes of water $\left(\delta^{2} \mathrm{H}_{\mathrm{H} 2 \mathrm{O}}\right.$ and $\left.\delta^{18} \mathrm{O}_{\mathrm{H} 2 \mathrm{O}}\right)$ provide insight to the origin of the water, while the $\delta^{13} \mathrm{C}_{\mathrm{DIC}}$ and $\delta^{34} \mathrm{~S}_{\mathrm{SO} 4}$ ratios help in distinguishing sources of dissolved components (Mutlu et al., 2007; Siegel et al., 2004; Hobba et al., 1979; Qin et al., 2005; Favara et al., 2001; Fouillac et al., 1990; Garchar and Arehart, 2008; Koski 
and Wood, 2004). Additionally, isotopic geothermometry has been applied to predict temperatures at depth of geothermal systems (Pang, 2001; Qin et al., 2005; Garchar and Arehart, 2008; Mutlu, 2007).

In the past, geothermal waters were thought to originate from magma-derived fluids that surfaced through fracture zones in the rock. More recent literature has confirmed most geothermal waters are meteorically-derived fluids which have been circulated at depth (Clark and Fritz, 1997). Stable isotopes of water are especially informative regarding the origin of these waters and their recharge sources since their distribution and modifications are well defined by the meteoric water line. Craig (1963) showed that hightemperature geothermal systems have waters that are consistent in $\delta^{2} \mathrm{H}$ to local precipitation but are often enriched in $\delta^{18} \mathrm{O}$. This enrichment has been attributed to oxygen exchange in the water molecule and oxygen in silicate and/or carbonate minerals in the rock matrix (Kharaka and Mariner, 2005) (Fig. 2.7). As meteoric water infiltrates through the ground to form a geothermal reservoir, the water is in isotopic disequilibrium with the surrounding rock matrix and therefore oxygen exchange occurs and is controlled by the temperature (Geyh, 2001). The deuterium values are not significantly altered by water-rock exchange reactions because most rocks have very little hydrogen in their structures. In contrast to high-temperature systems, isotopic compositions of water can be significantly different in low-temperature systems. In low-temperature systems $(<300$ ${ }^{\circ} \mathrm{C}$ ) processes such as hydration of silicate minerals and retrograde exchange between water and silicate minerals can result in enriched values of $\delta^{2} \mathrm{H}$ and depleted values of $\delta^{18} \mathrm{O}$ (Fig. 2.7). In addition to exchange reactions, mixing of waters can also alter the 
isotopic composition of spring water. Ranges in $\delta^{18} \mathrm{O}$ and $\delta^{2} \mathrm{H}$ of various rock and water reservoirs are displayed in Figures 2.5 and 2.6.

Stable carbon isotopes in spring systems also provide insight about the origin and history of matrix fluids. Carbon isotopes can indicate the various types and extent of chemical reactions between groundwater, carbonate minerals and organic matter (Hobba et al., 1979). Determining carbon sources and the extent of these reactions have been the focus of many studies (Siegel et al., 2004; Hobba et al., 1979; Du et al., 2006; Mutlu, 2007). The ${ }^{13} \mathrm{C}$ values of $\mathrm{CO}_{2}$ discharged from spring systems can be distinguished between organic sources $(<-20 \%)$, and dissolution of carbonate rocks by organicallyderived $\mathrm{CO}_{2}(\sim-12 \%)$. Enriched values may result from degassing of $\mathrm{CO}_{2}$ at the surface, or could originate from mantle or an igneous melt source which has typical values of $\delta^{13} \mathrm{C}$ in the range of $\sim 0$ to $-4 \%$ (Siegel et al., 2004, Clark and Fritz, 1997).

Another application of stable isotopes in thermal springs is geothermometry. Isotopic geothermometers are models based on temperature-dependent fractionations from which temperatures at depth can be predicted. Predicting reservoir temperatures is an important aspect in geothermal resource assessment (Pang, 2001). The most widely used isotope geothermometer is based on the fractionation of ${ }^{18} \mathrm{O}$ between dissolved sulfate and water (Kharaka and Mariner, 2005). The well-studied Zhangzhou geothermal field in China applied this technique and discovered temperatures at 90 meters depth were $122{ }^{\circ} \mathrm{C}$ in contrast to $114{ }^{\circ} \mathrm{C}$ at the well head (Pang, 2001; Geyh, 2001). This study will focus on using stable isotopes in a natural spring setting to characterize and determine the origin and cycling of water and carbon at these locations. 


\subsubsection{Coal mine drainage}

The Appalachian Basin is one of the main coal producing regions in the U.S. Much of the Appalachian region is affected by pollution from acid or alkaline mine drainage to its receiving streams from abandoned surface and deep coal mines (EPA, 2008). Pollution from coal mining has the potential to degrade water quality of surrounding streams and/or groundwater and can also be harmful to aquatic life. Generation of mine discharge often results from atmospheric exposure and weathering of pyrite and other metal-sulfides, producing sulfuric acid and mobilizing metals into the groundwater and surface water which can be toxic to aquatic life (Gammons et al., 2009). The production of sulfuric acid can further drive the dissolution of carbonate rocks, which in turn could result in coal mine drainage with high $\mathrm{CO}_{2}$ concentrations and a low $\mathrm{pH}$. This enhanced chemical weathering could release old carbon sequestered as carbonate minerals to the atmosphere. Additionally, the added carbon could escape to the atmosphere via $\mathrm{CO}_{2}$ evasion, or be exported as dissolved inorganic carbon.

The stable isotopes of hydrogen, oxygen, carbon and sulfur are useful proxies in mine waters as means of evaluating the history and nature of the water and its related components. These stable isotopes are useful in a mine drainage setting since $\mathrm{H}$ and $\mathrm{O}$ make up the water molecule and much of the weathering of mine-related environments involves interaction between sulfide minerals (i.e. pyrite), water and molecular oxygen (Seal, 2003). Thus, these stable isotopes aid in understanding sources of water in addition to the physical, chemical and biological processes that may have attributed to the discharging water. 
Various studies have investigated the use of stable isotopes in coal mine settings. Stable isotopes of water $\left(\delta^{18} \mathrm{O}_{\mathrm{H} 2 \mathrm{O}}\right.$ and $\left.\delta^{2} \mathrm{H}_{\mathrm{H} 2 \mathrm{O}}\right)$ have been used to delineate sources of water in coal mining environments (Ghomshei and Allen, 1999; Gammons et al., 2009; Hazen et al., 2002; Seal, 2003). For example, one study showed that in an abandoned mine in Colorado, precipitation and mine water samples plot along the same regression line, indicating that the mine water was hydrologically-connected to meteoric recharge (Hazen et al., 2002). Mine waters are subject to the same hydrological processes that affect normal groundwaters and surface waters and can therefore be compared to groundwater in the region.

Stable carbon isotopes of DIC $\left(\delta^{13} \mathrm{C}_{\text {DIC }}\right)$ have been used in several studies to assess the impact of pollution by mine drainage (Fonyuy and Atekwana, 2008; Atekwana and Ali, 2009). Surface waters impacted by mine drainage are often acidic and further produce acidity by metal hydrolysis. Changes in $\mathrm{pH}$ resulting from mine discharge pollution affect the speciation of DIC, driving it toward carbonic acid $\left(\mathrm{H}_{2} \mathrm{CO}_{3}\right)$, which subsequently dissociates into $\mathrm{CO}_{2(\mathrm{aq})}$. The $\mathrm{CO}_{2}$ can then degass, consequently enriching the residual DIC in ${ }^{13} \mathrm{C}$ due to preferential loss of ${ }^{12} \mathrm{C}$ to the atmosphere. The $\delta^{13} \mathrm{C}_{\mathrm{DIC}}$ has also been used to investigate the existence of bacterially-mediated reactions. The resulting $\delta^{13} \mathrm{C}_{\text {DIC }}$ signature will generally be depleted in ${ }^{13} \mathrm{C}$ since microbes utilize depleted organic matter ( - $26 \%$ ) (Burns, 1998).

A majority of stable isotope research in mine settings focuses on $\mathrm{S}$ and $\mathrm{O}$ isotopes of dissolved sulfate in conjunction with $\mathrm{O}$ and $\mathrm{H}$ isotopes of water to determine sources of sulfate and mechanisms of sulfide oxidation as well as assessing waters impacted by coal mine drainage (Nordstrom et al., 2007; Wright and Nordstrom, 1999; Gammons et 
al., 2010; Seal, 2003; Van Donkelaar et al., 1995; Taylor et al., 1984; Mayo et al., 1992). These environments are dominated by oxidation of pyrite (Eqs. $2.12 \& 2.13$ ). There is negligible fractionation in sulfur isotopes from the parent source of sulfur to the produced sulfate in contrast to the oxygen isotopes which are greatly affected by reaction pathways, $\mathrm{pH}$ and different sources of oxygen (Seal, 2003). The $\delta^{18} \mathrm{O}_{\text {SO4 }}$ in these systems is typical of local meteoric waters while the $\delta^{34} \mathrm{~S}_{\mathrm{SO} 4}$ is typically representative of the pyrite in that region. Depleted isotopic compositions of sulfur have been shown to be consistent with pyrite oxidation and oxidation of organic sulfur compounds (Taylor and Wheeler, 1984; Krouse, 1996). Wright and Nordstrom (1999) used oxygen isotopes as a tool to distinguish sources of dissolved sulfate (either natural or mine-related) in a watershed affected by abandoned mines in order to implement remediation and assess water-quality. Other studies have focused on the effect of sulfate reduction on the isotopes of $\mathrm{SO}_{4}{ }^{2-}$ (Roesler et al., 2007; Gammons et al., 2010; Brunner et al., 2005; Church et al., 2007). In general, the residual sulfate from equations 2.10 and 2.11 is enriched in ${ }^{34} \mathrm{~S}$ and ${ }^{18} \mathrm{O}$ relative to the produced sulfides since microbes will preferentially metabolize the lighter isotopes $\left({ }^{32} \mathrm{~S}\right.$ and $\left.{ }^{16} \mathrm{O}\right)$.

This study will focus on using stable isotopes in a coal mine drainage setting to investigate sources of water and carbon as well as biogeochemical processes involved in the evolution of this mine discharge. Coal mine discharge sites thus offer a distinct natural setting to asses water quality and track recharge sources as well as understanding its role in the global carbon cycle. 


\subsubsection{Shale gas drilling produced water}

Produced water (or flowback water) from the shale gas drilling process typically contain salts, metals and organics as a result of a mixture of the fracturing water-fluid solutions and the already existing brine formation waters (Hayes, 2009; Warner et al., 2012; Chapman et al., 2012). The chemical composition of the flowback water will depend on the initial composition of the fracturing water-fluid solution used, and the amount of time it is in contact with formations. Currently, not much research has been conducted in understand the chemistry of flowback water. Hayes (2009) explored the chemistry of 19 vertical and horizontal Marcellus shale formation wells before hydraulic fracturing took place and the subsequent flowback samples from day 1, 5, 14 and 90 days after hydraulic fracturing. The researchers also analyzed water samples before the mixing of the additives. The authors from this study concluded that the general chemistry $(\mathrm{pH}$, alkalinity, TOC, oils/greases) were within normal ranges for produced waters and that they are dominated by $\mathrm{Na}, \mathrm{Ca}$ and $\mathrm{Cl}$. Additional geochemical studies which focused on the Marcellus shale flowback waters include Chapman et al. (2012) and Warner et al. (2012). Chapmen et al. (2012) investigated the utility of Sr isotopes as potential tracers to identify and quantify any possible interaction of the produced waters with other waters in the region, concluding that $\mathrm{Sr}$ isotope ratios can be used to differentiate between Marcellus produced waters and other sources of total dissolved solids. Warner et al. (2012) also integrated isotopes ( $\mathrm{Sr}, \mathrm{H}, \mathrm{O}$ and $\mathrm{Ra}$ ) along with chemical data of produced waters to explore the possibility of hydraulic connectivity between deep shale formations and overlying shallow aquifers. The results from this research showed no relationship of saline groundwaters with locations of shale gas drilling. Other studies focused on shale 
gas drilling include sourcing water and natural gas using $\mathrm{C}$ and $\mathrm{H}$ isotopes of methane and/or ethane and C isotopes of DIC (Osborn and McIntosh, 2010; Osborn et al., 2011; Cheung et al., 2010, Sharma and Baggett, 2011). Osborn and McIntosh (2010) determined sources of water and natural gas in Devonian organic-rich shales and reservoir sands in the northern Appalachian Basin using geochemistry and isotopes of methane and dissolved inorganic carbon. Blauch et al. (2009) examined the chemistry of flowback water in two Marcellus wells along with additional proxies to determine sources of salinity in these waters.

Many studies have investigated the use of stable isotopes and additional geochemistry proxies to determine sources of brines (Maekawa et al, 2006; Wittrup et al., 1987; Kesler et al., 1996; Olivero et al., 1987; Kharaka and Berry, 1973; Warner et al., 2012, Chapman et al., 2012). The $\delta^{18} \mathrm{O}$ and $\delta^{2} \mathrm{H}$ of water can aid in distinguishing the extent of mixing of seawater and meteoric water since meteoric water is much more depleted in the heavy isotopes than seawater. The formation waters may be true connate water or meteoric water that has resided long enough to react with the host rock, both resulting in ${ }^{18} \mathrm{O}$ enrichment. A better understanding of the chemical characteristics and sources of the flowback water is required to effectively manage the large quantities of water produced from this process. 


\section{CHAPTER 3}

\subsection{Site Description and Methodology}

\subsection{Geological Setting and Site Descriptions}

Study sites for this research have been chosen in Pennsylvania, West Virginia and

Virginia (Fig. 3.0). Specific site information can be found summarized in the Appendix, Table 1.0.

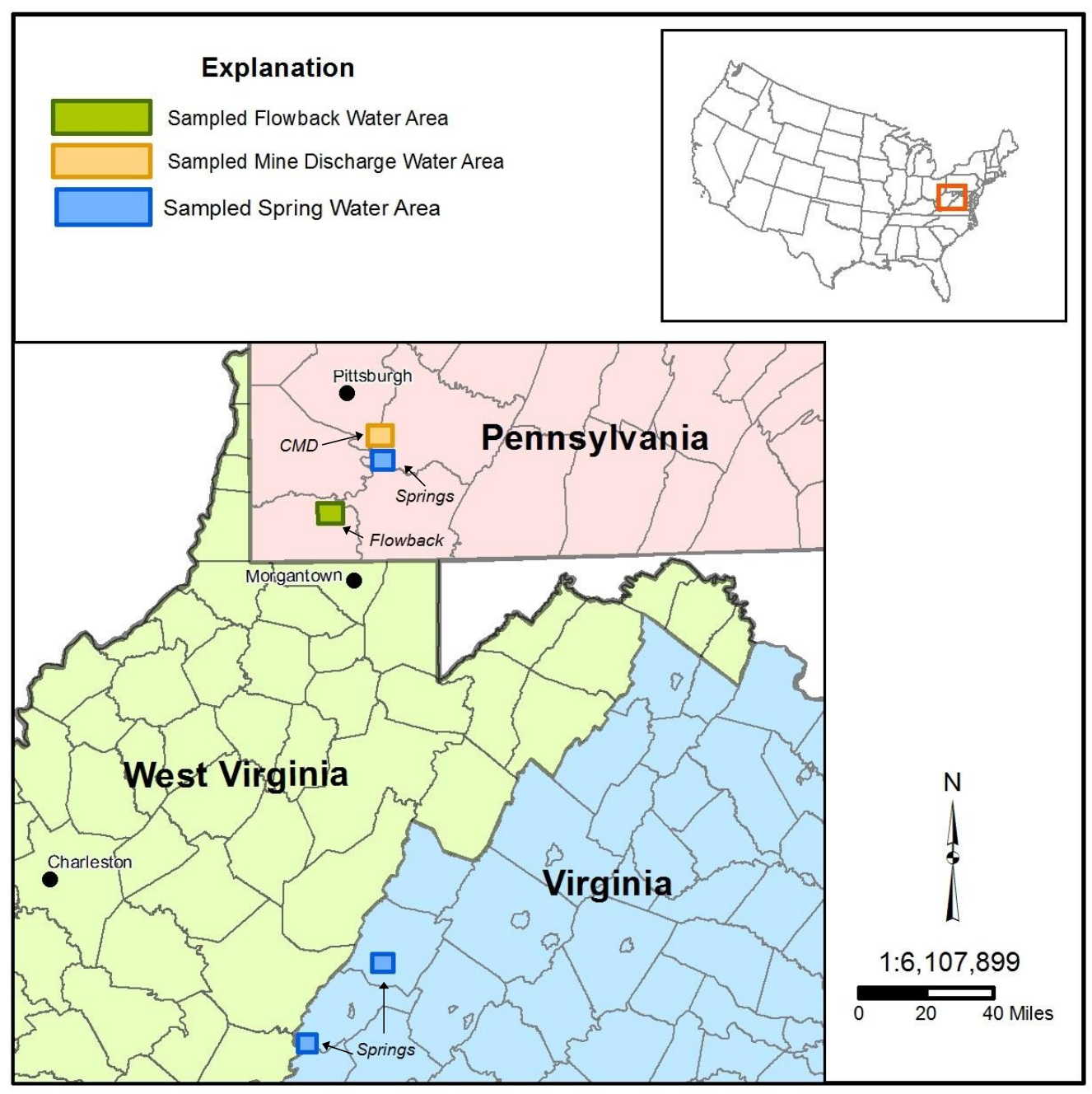

Figure 3.0 - Sample location map. Boxes denote the general areas of sampling sites. 
The springs located in Pennsylvania include Port Royal, Cedar Creek, Smithton and Mayview. The one spring located in Monroe County West Virginia is Old Sweet spring. Springs in Virginia include Octagon, Magnesia, Boiler and Hot Sulfur springs which are all located in the Homestead Resort in Bath County, Virginia. Jefferson and Big springs are also in Bath County, but are not part of the resort. Sweet Chalybeate spring and Spellman spring are located in Alleghany County, Virginia. The shale gas drilling site is located in Greene County, Pennsylvania and consists of 3 sampling sites: Blaker-8, Meadows-4 and Mohr-6. Finally, the coal mine drainage sampling location (Iron Falls) is located in near Blythedale, PA in Allegheny County, PA. Iron falls was chosen to research as collaborative efforts with Jim Adams while Old Sweet spring, Sweet Chalybeate spring and Spellman spring were investigated with John Moore, both WVU graduate students. The major ion data and $\mathrm{CO}_{2}$ chemistry for the sites for Iron Falls, Old Sweet spring, Sweet Chalybeate spring and Spellman spring was previously reported in theses of Jim Adams and John Moore (Adams, 2012; Moore, 2012). All other springs were studied as part of collaborative efforts between WVU and DOE/NETL in Pittsburgh, PA. All sampling sites have very different geochemical environments and their diversity offer unique natural laboratories to understand evolution of $\mathrm{O}, \mathrm{H}, \mathrm{C}$ and $\mathrm{S}$ isotopic composition of different kinds of waters.

The springs in Virginia and West Virginia focused on in this study are located within the Valley and Ridge Province in Virginia and West Virginia. The structural complexity of this area is a result of the Alleghenian Orogeny 320 mya, which corresponded to a large mountain-building event associated with large folds and thrust faults in the central Appalachian Mountain region (Hobba, 1979). An effect of this 
deformation was the sedimentary rock in the basin was compressed perpendicular to the direction of forces. Deformation associated with the orogeny was the greatest in the southern Appalachians (North Carolina, Tennessee, Virginia, and West Virginia) where series of thrust faults and folds developed in addition to the large folds, with the amount of deformation lessening to the north (Evans et al., 1999; USGS). The topography of the region makes it possible for deep circulation of meteoric waters and a combination of the lithology and structure provide conduits for the water to return to the surface (Hobba et al., 1979).

The springs in WV and VA are stratigraphically located in Ordovician aged carbonate rocks along the axes of anticlines or on the flanks of anticlines in SiluroDevonian limestones (Rader and Gathright, 1984). The Ordovician age rocks are primarily in the Beekmantown group, which is composed of thick-bedded limestones and dolomite. The Silurian-Devonian system includes the Helderburg group and the Tonoloway and Wills Creek formations, which are comprised of mainly limestones with chert, sandstone and shale also present (USGS, http://mrdata.usgs.gov/). The springs in this area are both warm and cold springs, ranging in temperatures from 12 to $40{ }^{\circ} \mathrm{C}$.

The springs in Pennsylvania are located in Westmoreland and Allegheny counties (Fig. 3.0). These springs are

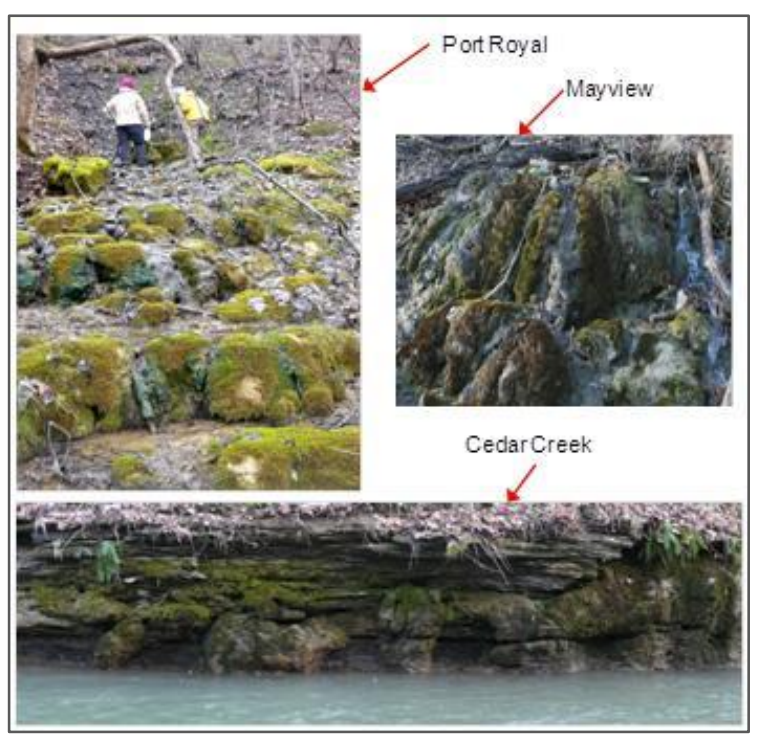

Figure 3.1- $\mathrm{CaCO}_{3}$ deposits (tufa) at spring sites in PA. These springs are actively precipitating tufa. 
actively precipitating calcium carbonate deposits, also known as tufa (Fig. 3.1). The formation of these deposits plays an important role in understanding inorganic chemistry, the reactions involved in carbon transformations as well as sources of water. The carbonate rocks in this area are Pennsylvanian in age ( 318 - 299 mya) and are included in the Monongahela and Allegheny groups. The primary limestone unit in this region is the Bentwood formation of the Monongahela group (Fig. 3.2).

The coal mine drainage study site, Iron

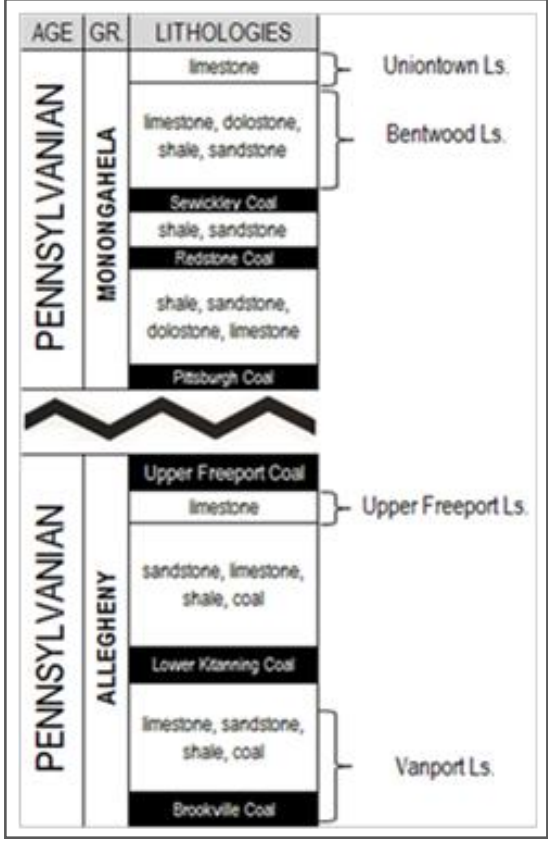

Figure 3.2-Modified stratigraphic column for spring sites in PA. Note the important limestone units (Capo et al., 2001).

Falls, is located near Blythedale, PA in Allegheny County, Pennsylvania (Fig. 3.0). This

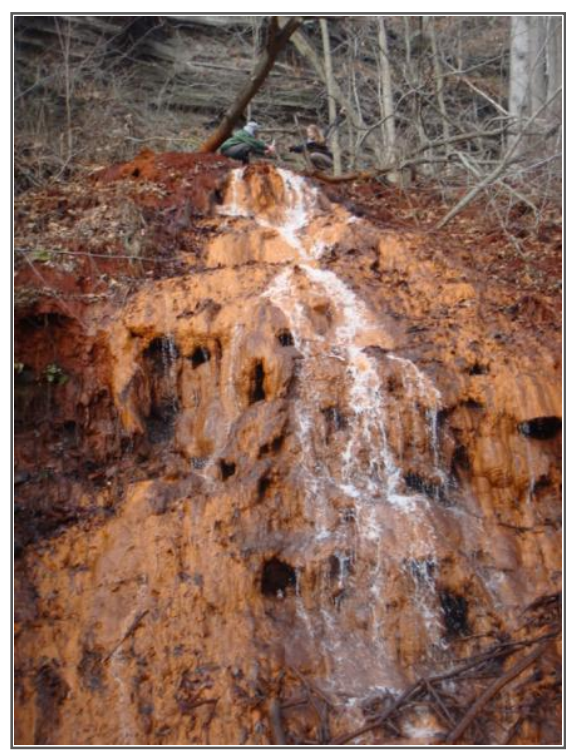

Figure 3.3-Photograph of Iron Falls. Discharge point is at the top of 10m high waterfall covered in iron oxyhydroxides. abandoned mine discharged from the Ocean \#2 mine which operated in the late $19^{\text {th }}$ and early $20^{\text {th }}$ centuries and exploited the Pittsburgh coal seam (Metzgar, 2003). The mine portal was sealed in the late 1960 s to flood the mine and reduce acid formation. Currently at this site, alkaline mine drainage is discharging from the portal and pipes below the portal where it then drops over $\sim 10 \mathrm{~m}$ high waterfall covered in iron oxides/iron hydroxides giving the falls its suitable name (Fig. 3.3). The discharge subsequently travels $150 \mathrm{~m}$ downstream where is intersects with the 
Youghiogheny River (Adams, 2012).

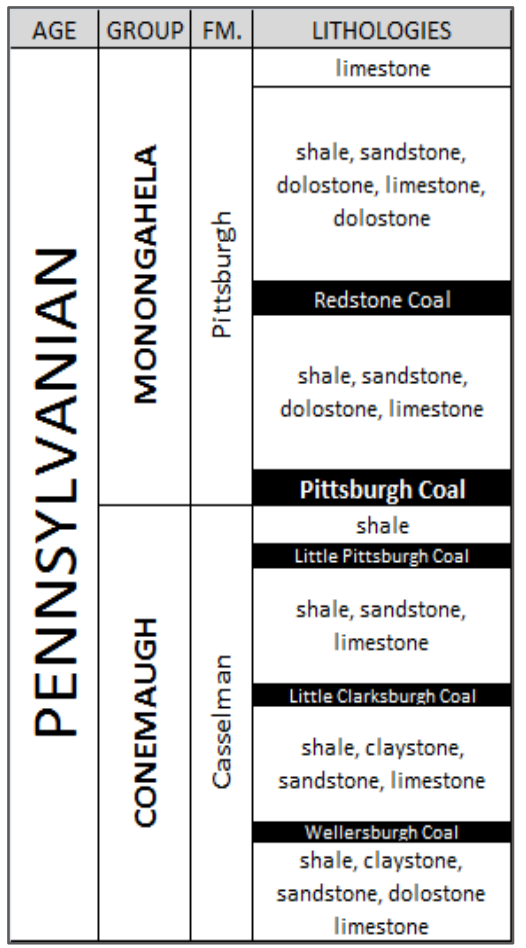

Figure 3.4-Modified stratigraphic column for coal mine discharge area. Note the coal units (modified from Capo et al., 2001; Adams, 2012)
The geology of this site is typical of coalproducing areas in the Appalachian region (Brady et al., 1998). The site is located at the base of the Pittsburgh formation of the Monongahela group, a Pennsylvanian $(\approx 290 \mathrm{Ma})$ rock unit in the eastern limb of Irwin Syncline (Capo et al., 2001). The Monongahela group is divided into the Pittsburgh and Uniontown formations and extends from the base of the Pittsburgh coal to the base of the Waynesburg coal. The group is about 119 meters thick and has been interpreted as purely freshwater deposits, dominated by limestones, dolostones, mudstones, shales, siltstones and a few coals (Fig. 3.4).

The Shale Gas Drilling study area lies in Greene County, Pennsylvania within the Monongahela River basin of southern Pennsylvania and north-central West Virginia, where natural gas is being extracted from Shallow Devonian sands and the Marcellus shale (Fig. 3.0). The geology of the study area is rather complex due to three distinct orogenic events from Middle Ordovician to Permian time periods (DOE/NETL, 2011). The shale unit of interest, the Marcellus, covers an estimated area of 95,000 square miles underlying parts of West Virginia, Pennsylvania, New York and Ohio and ranges in depth from 4,000 to 8,500 $\mathrm{ft}$ (Fig. 3.5). Middle-Devonian in age, this marine shale deposited in the Appalachian basin >350 mya is rich in organic matter and ranges in 
thickness from 50 to $250 \mathrm{ft}$. It has been estimated that the thickness can be up to $900 \mathrm{ft}$ in some place, with thinner portions towards the northern end (Andrews et al., 2009). The Marcellus shale also underwent significant structural deformation during the last orogeny which resulted in a complex structural system containing numerous faults and fractures. These structural deformations can create preferential flow paths for water and dissolved constituents to migrate.

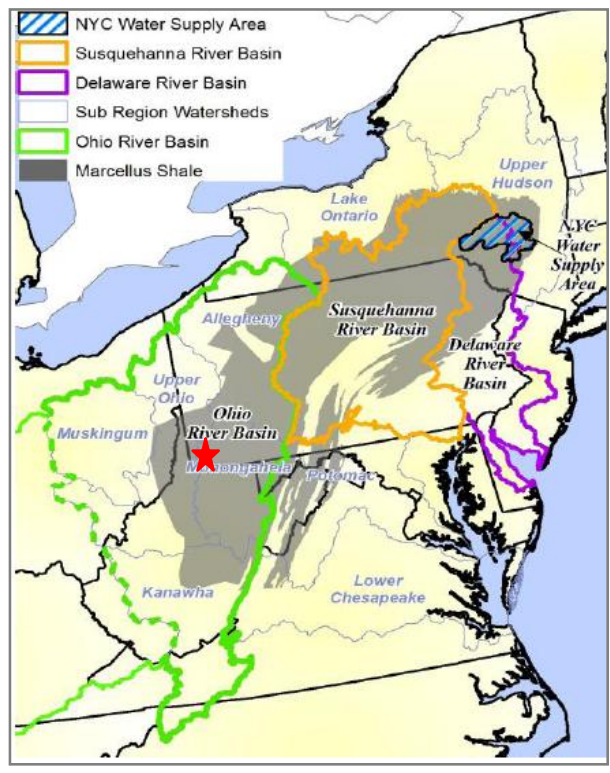

Figure 3.5-Extent of Marcellus shale formation. Note the star represents sampling site in this study (modified from Arthur et al., 2010).

Overlying the Marcellus shale formation

are thousands of feet of rock layers composed of siltstones and shales layered with sandstones and limestones. Generally, these layers are thicker in the northern and eastern portions where the Marcellus is the deepest, while the western and southern areas are separated by a thinner layer of rock where the Marcellus is shallower. Shallow aquifers, which provide freshwater for many communities, lie stratigraphically above these rock units. The stratigraphy of these units is specific to the geographic area. In New York, northern Pennsylvania and northeastern Ohio, the shallow aquifers are mainly glacial sands and gravels as well as Mississippian aquifers. In Pennsylvania and eastern West Virginia, aquifers are composed mainly of Valley and Ridge carbonate rocks. The likelihood of contaminated waters traveling upward to these aquifers is very low considering the proximity and thickness of these aquifers $(\sim 100$ 's $\mathrm{ft}$ thick and near 
surface) and the ability of the layers in between to act as confining layers, inhibiting vertical migration of fluids (Andrews et al., 2009).

\subsection{Sample Collection and Preparation}

\begin{abstract}
Water samples
were taken at or near the

discharge points for springs and coal mine

discharge sites (Figs. 1.1,

3.1 and 3.3). If the exact
\end{abstract}

discharge point was

unidentifiable, sample

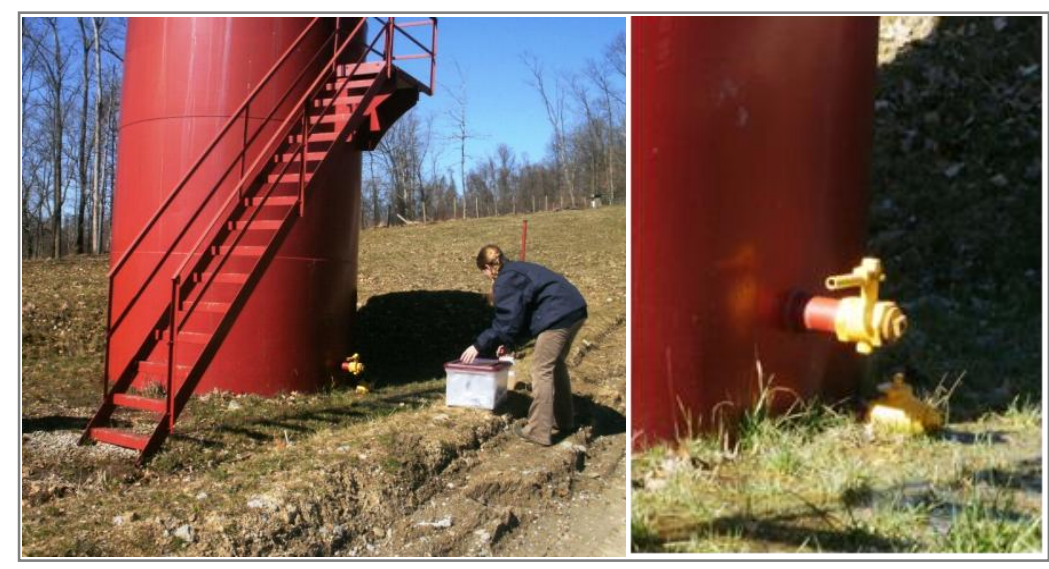

Figure 3.6 - Sampling flowback waters from holding tank. Close up of spigot from holding tank at shale gas drilling site (right). Samples were taken directly from the bottom being careful to minimize atmospheric exposure.

were taken as close to

source as possible. Water samples co-produced from shale gas drilling were taken from a spigot at the bottom of a storage tank on site (Fig. 3.6). Care was taken to eliminate atmospheric exposure when sampling by slowly opening the spigot and collecting water as close to the tank as possible.

For the natural spring and coal mine discharge sites, samples were collected after field parameter measurements (i.e. temperature, conductivity, $\mathrm{pH}$, dissolved oxygen, ORP) were obtained with a YSI-556MP meter which was calibrated for $\mathrm{pH} 4.0$ and 7.0 and for ORP with Zobell solution in the field (Appendix, Table 2). Calibration for specific conductance was done with $1409 \mu \mathrm{S} / \mathrm{cm}^{2} \mathrm{KCl}$ solution and calibration for 
dissolved oxygen was done by exposing the meter probe to the atmosphere for 10 minutes (Moore, 2012; Adams, 2012).

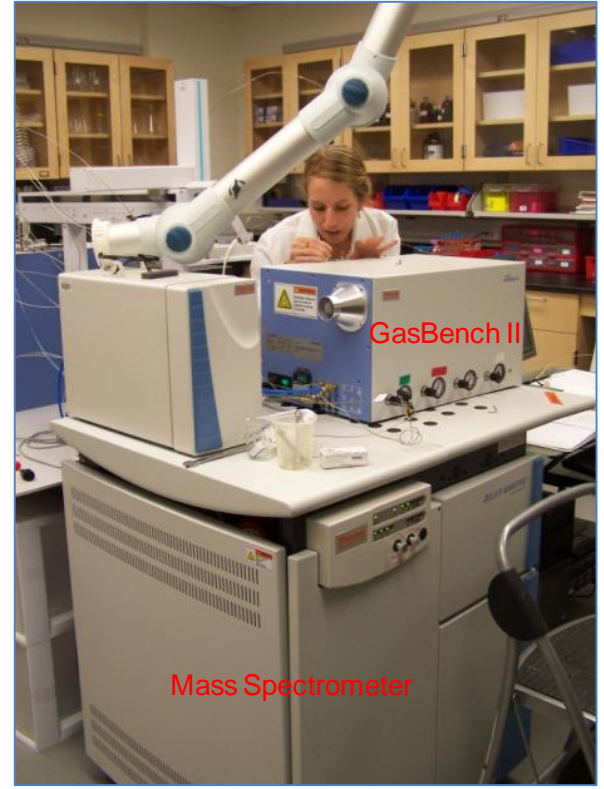

Figure 3.7-GasBench II device coupled to a Finnigan Delta Plus mass spectrometer at the West Virginia Stable Isotope Laboratory.

Isotope samples were collected at each sampling location for $\delta^{2} \mathrm{H}_{\mathrm{H} 2 \mathrm{O}}$ and $\delta^{18} \mathrm{O}_{\mathrm{H} 2 \mathrm{O}}, \delta^{13} \mathrm{C}_{\mathrm{DIC}}$ and for $\delta \mathrm{S}_{\mathrm{SO} 4}$ and $\delta \mathrm{O}_{\mathrm{SO} 4}$ (Appendix, Table 3 ). Random duplicate samples of were also taken for quality control checks. Samples for $\delta^{2} \mathrm{H}_{\mathrm{H} 2 \mathrm{O}}$ and $\delta^{18} \mathrm{O}_{\mathrm{H} 2 \mathrm{O}}$ were collected by filling an $8 \mathrm{~mL}$ glassthreaded vial with no headspace. Parafilm was used to seal caps and samples were refrigerated at $\sim 4{ }^{\circ} \mathrm{C}$ until analysis. Samples collected for $\delta^{13} \mathrm{C}_{\mathrm{DIC}}$ were filtered using a $60 \mathrm{~mL}$ Luer-Lok syringe fitted with a Cameo $0.45 \mu \mathrm{m}$ nylon pre-filter into a $10 \mathrm{~mL}$ Wheaton serum vial with no headspace. About two drops of benzalkonium chloride (17\% w/w) was added to the vial as a preservative. A $20 \mathrm{~mm}$ Teflon/Butyl septum was then placed on the top and sealed with aluminum caps using a crimper. Samples for $\delta^{2} \mathrm{H}_{\mathrm{H} 2 \mathrm{O}}$, $\delta^{18} \mathrm{O}_{\mathrm{H} 2 \mathrm{O}}$ and $\delta^{13} \mathrm{C}_{\mathrm{DIC}}$ were analyzed on a GasBench II device coupled to a Finnigan Delta Plus mass spectrometer at the West Virginia Stable Isotope Laboratory (Fig. 3.7).

Dissolved sulfate samples were collected in a $1 \mathrm{~L}$ polyethylene bottle with no headspace. Each sample was then filtered through a $0.45 \mu \mathrm{m}$ PCM filter with the aid of a vacuum pump. The $1 \mathrm{~L}$ aqueous sulfate samples were subsequently precipitated as $\mathrm{BaSO}_{4}$ powder by first acidifying the sample to $\mathrm{pH} 2-3$ with $1 \mathrm{M}$ solution of $\mathrm{HCl}$ to remove any carbonate as $\mathrm{CO}_{2}$. The sample was then heated at $90{ }^{\circ} \mathrm{C}$ for 1 hour, continuously stirring. 
After this time, $5-10 \mathrm{~mL}$ of $20 \% \mathrm{BaCl}_{2}$ was added to the sample and the solution was allowed to precipitate and cool overnight. The solid $\mathrm{BaSO}_{4}$ precipitate was then collected by filtering the sample though a pre-weighed $0.2 \mu \mathrm{m}$ Isopore PCM filter (Fig 3.8). The filter containing precipitate was then dried in an oven at $90{ }^{\circ} \mathrm{C}$ overnight. The $\mathrm{BaSO}_{4}$ powder was then scraped off filter paper, weighed and homogenized with a spatula (Révész and Qi, 2006, USGS Reston Stable Isotope Laboratory, Reston, VA). Samples were stored in $2 \mathrm{~mL}$ plastic centrifuge tube until analysis. Solid precipitate was sent to University of Arizona's Environmental Stable Isotope Facility for analysis of $\delta \mathrm{S}_{\mathrm{SO} 4}$ and $\delta \mathrm{O}_{\mathrm{SO} 4}$ on an Elemental Analyzer coupled to a Finnigan Delta Plus mass spectrometer. Sulfate samples from the shale gas drilling sites were collected, but precipitation of
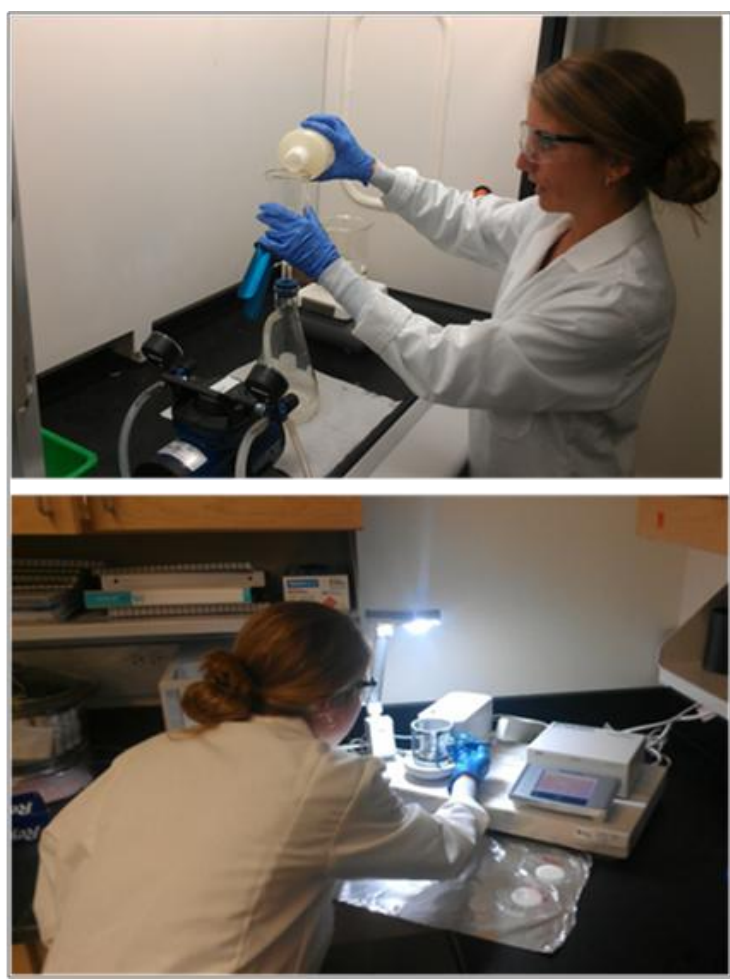

Figure 3.8- $\mathrm{BaSO}_{4}$ precipitation set up. Samples are filtered (top), precipitated out and subsequently weighed and homogenized (bottom).
$\mathrm{BaSO}_{4}$ was not feasible due to the high organic content of the samples and the difficulties involved in isolating pure $\mathrm{BaSO}_{4}$

Water samples for major cations and anions were collected by filtering water in the field through a $0.45 \mu \mathrm{m}$ filter using a $60 \mathrm{~mL}$ Luer-Lok syringe. Cation samples were collected in a $125 \mathrm{~mL}$ HDPE bottle and preserved with $1 \mathrm{~mL} \mathrm{HNO}_{3}$ to prevent precipitation. Anions samples were collected in a $60 \mathrm{~mL}$ HDPE bottle. All samples were kept on ice or refrigerated to 
minimize bacterial growth. Samples were analyzed at the U.S. Department of Energy's (DOE) National Energy and Technology Laboratory (NETL) located in Pittsburgh, PA. Inductively Coupled Plasma - Optical Emissions Spectroscopy (ICP-OES) was used for analysis of major cations on a Perkin Elmer Optima 3000 Radial View spectrometer using US EPA method 200.7. Ion Chromatography (IC) on a Dionex ion chromatography system was used for major anions (Appendix, Table 4).

Field titrations were done at the coal mine discharge and spring sites using the Gran Titration technique to titrate to $\mathrm{pH} 4.2$ and 3.9 to calculate bicarbonate $\left(\mathrm{HCO}_{3}{ }^{-}\right)$ concentrations in the waters (Rounds, 2006). Detailed methods are included in Moore (2012) and Adams (2012). A sample volume of $25 \mathrm{~mL}$ was poured into an Erlenmeyer flask and a Hach digital titrator was used to add $1.6 \mathrm{~N} \mathrm{H}_{2} \mathrm{SO}_{4}$. A Hanna pH meter (model 9025) was calibrated using $\mathrm{pH} 7.0$ and 4.0 solutions. The $\mathrm{pH}$ of the sample was recorded then lowered to the specific endpoints with the addition of the acid. Alkalinity was then calculated as $\mathrm{mg} / \mathrm{L} \mathrm{HCO}_{3}{ }^{-}$. Alkalinity samples for the shale gas were collected in field and subsequently analyzed at the DOE/NETL in Pittsburgh, PA. The samples were analyzed by use of a Metrohm automatic titrator (Metrohm USA Inc., Riverview, FL). A known volume of water sample was titrated with a standard solution of sulfuric acid to an electrometric $\mathrm{pH}$ endpoint of 4.5. In addition to free $\mathrm{OH}$, this method neutralizes all titratable bases including $\mathrm{HCO}_{3}^{-}, \mathrm{CO}_{3}{ }^{2-}$, silicate, borate ammonia, phosphate, arsenate, aluminate and organic anions (Method SM 2320, American Public Health, 2005) (Appendix, Table 5). 


\subsection{Analytical Methods}

The $\mathrm{O}$ and $\mathrm{H}$ isotopes of water and $\mathrm{C}$ isotope of DIC were analyzed at the West Virginia University Stable Isotope Laboratory (WVSIL). Samples were analyzed with a Finnigan Delta V Plus Advantage isotope ratio mass spectrometer (Thermo Scientific) using continuous flow techniques (CF-IRMS). Using continuous flow techniques, in which the sample is entrained in a carrier gas (He), allows for online sample preparation and high precision of isotope ratio measurements. The mass spectrometer is interfaced with a Thermo Quest Finnigan ${ }^{\mathrm{TM}}$ GasBench II device which is a universal on-line gas preparation and introduction system for the IRMS. The GasBench II device is supported by a GC-PAL auto-sampler system. This system has many applications not limited to but including the ones being used in this study $-\mathrm{D} / \mathrm{H}$ and ${ }^{18} \mathrm{O} /{ }^{16} \mathrm{O}$ in waters using headspace equilibration method and ${ }^{13} \mathrm{C} /{ }^{12} \mathrm{C}$ of dissolved inorganic carbon.

Figure 3.9 is a schematic diagram of the GasBench II. Each sample is flushed with the appropriate flushing gas and equilibrated for 24 hours at $25{ }^{\circ} \mathrm{C}$ in the autosampler tray. The headspace gas is analyzed using a two port needle adding a continuous stream of $\mathrm{He}(\sim 0.5 \mathrm{~mL} / \mathrm{min})$ into the sample vial through one port which dilutes and displaces the sample gas, and sampling headspace gas $(10.0 \mu \mathrm{L}$ aliquot) through the other port simultaneously. Typically, 7 to 10 replicates of each sample are analyzed. The sample encounters a NAFION ${ }^{\mathrm{TM}}$ water trap (Fig. 3.9, insert A) which removes any excess water vapor before entering the Valco valve into the sample loop. The loop injector then aliquots $100 \mu \mathrm{L}$ of the sample gas onto the gas chromatograph (GC) system via the Valco valve. The GC column (25-m PoraPlot Q fused silica column with an inner diameter of $0.32 \mathrm{~mm}$ ) is responsible for separating the molecular species, for example $\mathrm{CO}_{2}$ from 
other gases such as $\mathrm{N}_{2}$. The GC column temperature is optimized at $75{ }^{\circ} \mathrm{C}$. Also controlled by the Valco valve is the automatic injection of reference gases which provide references for isotopic standards. After the sample travels through the GC column it passes through a second $\mathrm{NAFION}^{\mathrm{TM}}$ water trap before entering the IRMS via a silica capillary where the isotopes are separated out by mass (Torres et al., 2005; Thermo

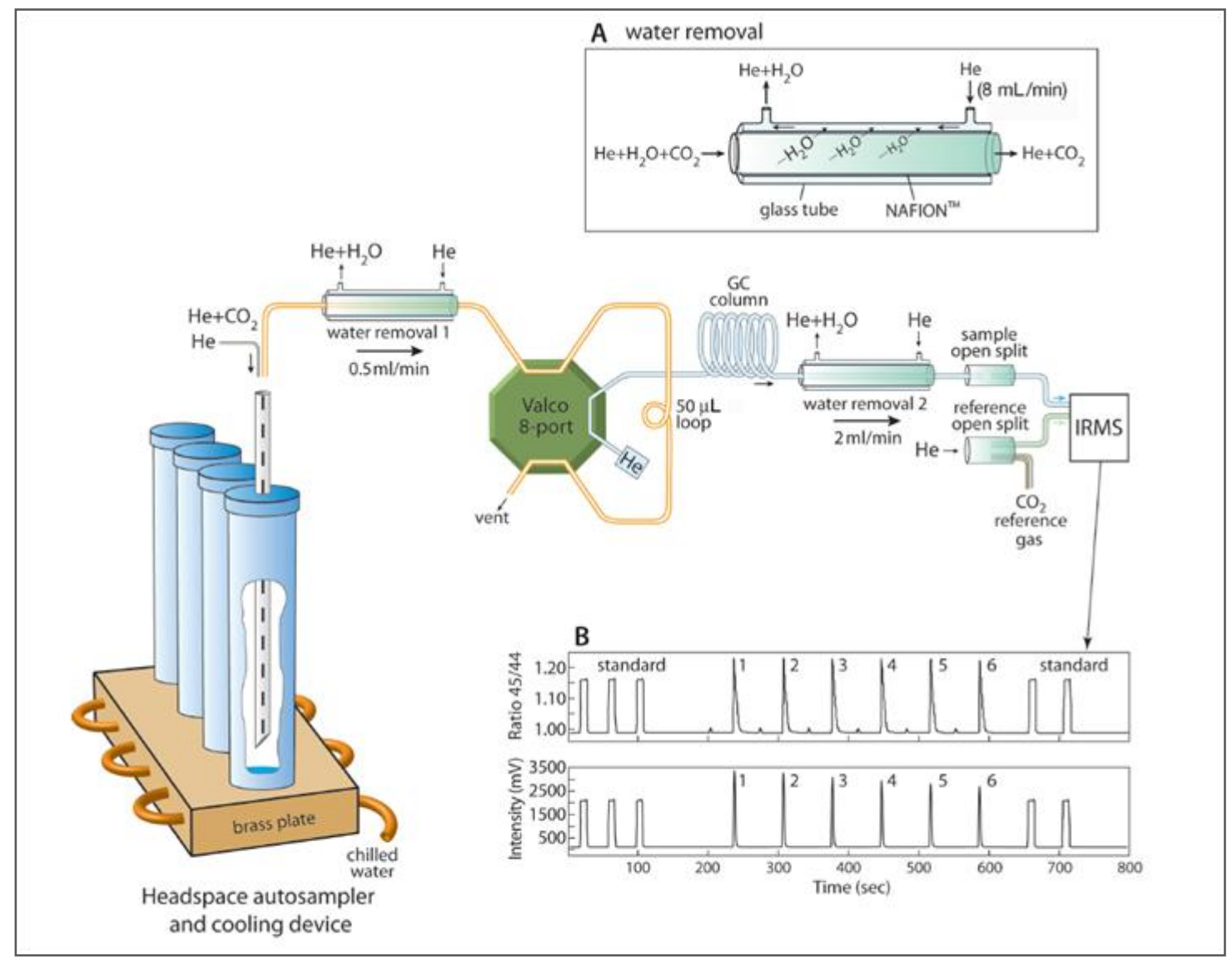

Figure 3.9-Schematic of GasBench II interfaced to an IRMS. Various components are displayed including water removal traps (insert A) (Torres et al., 2005). Note the yellow and blue lines depict capillaries in which the sample is carried in a stream of helium.

Electron Corp., 2004; ThermoFinnigan MAT, 2001; Wieser and Brand, 1996).

The IRMS software, ISODAT 3.0, is responsible for system controls, data acquisition and data evaluation. In the ISODAT software, methods and sequences are set up and communication with the auto-sampler is automatically controlled. A chromatogram containing reference peaks and sample peaks is produced for each sample 
(Fig. 3.10). The data is exported via an Excel template for data analysis. Further calculations are done in Excel and data is adjusted to international standards for

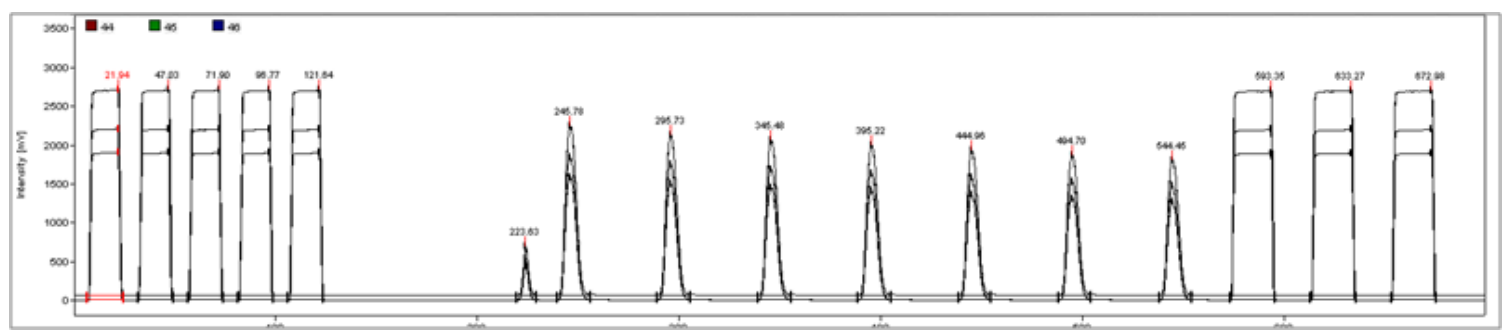

Figure 3.10 - Chromatogram produced by the ISODAT 3.0 software system. Note the reference gas peaks and the beginning and end of each sample run. Sample peaks (middle) vary from 7-10 peaks.

comparison. Internal lab standards which were previously calibrated against IAEA reference standards are incorporated and the beginning and end of each sequence and duplicates were run at random for $\mathrm{QA} / \mathrm{QC}$ checks.

The first step in analysis of $\delta^{13} \mathrm{C}_{\mathrm{DIC}}$ is the addition of $60 \mu \mathrm{L}$ of phosphoric acid $\left(\mathrm{H}_{3} \mathrm{PO}_{4}\right)$ with a gastight syringe to clean round-bottomed Labco® $10 \mathrm{~mL}$ auto-sampler vials. Vials were then flushed with pure He followed by the addition of $500 \mu \mathrm{L}$ of sample water collected in field. Vials were shaken on a Vortex-Genie® 2 mixer for $\sim 2$ minutes to liberate $\mathrm{CO}_{2}$ gas from carbon species in the water and allowed to equilibrate for 24 hours. The headspace gas was then measured using continuous flow isotope ratio mass spectrometry (CF-IRMS). Internal laboratory normalization standards for measurements of $\delta^{13} \mathrm{C}_{\text {DIC }}$ include $\mathrm{CaCO}_{3}$ and Le Grande limestone, calibrated against international atomic energy agency (IAEA) Vienna Pee Dee Beleminite (VPDB) standard. In addition to

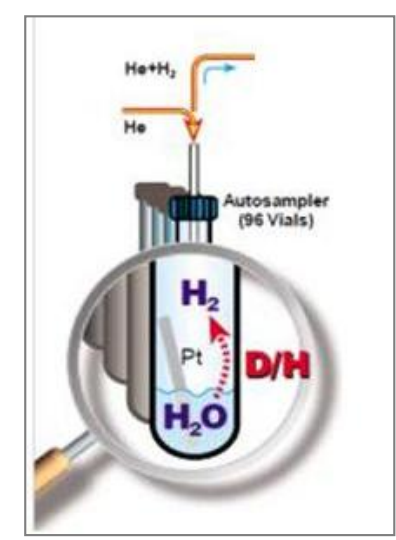

Figure 3.11-Platinum catalyst for $\mathrm{D} / \mathrm{H}$ ratio measurements (Thermo Scientific). 
normalization standards, an internal lab check standard, Morgantown tap water was run within each sequence. The precision for $\delta^{13} \mathrm{C}_{\mathrm{DIC}}$ was $\pm 0.05 \%$.

The $\delta^{2} \mathrm{H}_{\mathrm{H} 2 \mathrm{O}}$ and $\delta^{18} \mathrm{O}_{\mathrm{H} 2 \mathrm{O}}$ values are analyzed using a similar equilibration method as $\delta^{13} \mathrm{C}_{\mathrm{DIC}}$. A $500 \mu \mathrm{L}$ aliquot of sample was added to flat-bottom Labco® $10 \mathrm{~mL}$ autosampler vials. For $\delta^{18} \mathrm{O}_{\mathrm{H} 2 \mathrm{O}}$, vials are flushed with a blend of $\mathrm{CO}_{2}$ in $\mathrm{He}$ mix (Airgas, Morgantown, WV) and $\mathrm{CO}_{2}$ is used as the reference gas. For $\delta^{2} \mathrm{H}_{\mathrm{H} 2 \mathrm{O}}$, vials are flushed with a blend of $\mathrm{H}_{2}$ in $\mathrm{He}$ mix and $\mathrm{H}_{2}$ is used as the reference gas. The analysis of $\delta^{2} \mathrm{H}_{\mathrm{H} 2 \mathrm{O}}$ also requires the addition of a platinum catalyst during flushing and equilibration to accelerate exchange processes (Fig. 3.11). Internal lab standards for measurements of $\delta^{2} \mathrm{H}_{\mathrm{H} 2 \mathrm{O}}$ and $\delta^{18} \mathrm{O}_{\mathrm{H} 2 \mathrm{O}}$ include the normalization standards, Hawaiian spring water and Eldorado water, which were calibrated against IAEA standards (SMOW, SLAP and GISP). In addition to normalization standards, an internal lab check standard was run within each sequence. In the case of $\delta^{2} \mathrm{H}_{\mathrm{H} 2 \mathrm{O}}$ and $\delta^{18} \mathrm{O}_{\mathrm{H} 2 \mathrm{O}}$ measurements, Morgantown tap water is used. Precision rates were $\delta^{18} \mathrm{O}_{\mathrm{H} 2 \mathrm{O}} \pm 0.05 \%$ and $\delta^{2} \mathrm{H}_{\mathrm{H} 2 \mathrm{O}} \pm 1.0 \%$.

Isotopes of dissolved sulfate, $\delta \mathrm{S}_{\mathrm{SO}}$ and $\delta \mathrm{O}_{\mathrm{SO} 4}$, were precipitated as $\mathrm{BaSO}_{4}$ and sent to the University of Arizona's Environmental Stable Isotope Facility for analysis. Samples were analyzed on an Elemental Analyzer (EA) coupled to a Finnigan Delta Plus mass spectrometer. The solid, homogenized $\mathrm{BaSO}_{4}$ precipitate was loaded in an autosampler. The sample was then automatically introduced into the EA where it was combusted with a flow of oxygen to form $\mathrm{SO}_{2}$ gas. The sample was carried via continuous flow to the IRMS system. Precision rates were $\delta \mathrm{O}_{\mathrm{SO} 4} \pm 0.5$ and $\delta \mathrm{S}_{\mathrm{SO} 4} \pm 0.2$. 


\subsection{Calculations}

The total concentration of DIC for each sample was calculated from the addition of the concentrations of carbonate, bicarbonate, and carbonic acid species. Bicarbonate concentration was derived from the alkalinity titration of each sample and $\mathrm{H}^{+}$ concentrations were derived from $\mathrm{pH}$ measurements. The concentration of the carbonate and carbonic acid were calculated using the following equations:

$$
\begin{aligned}
& {\left[\mathrm{H}_{2} \mathrm{CO}_{3}\right]=\left[\mathrm{H}^{+}\right]\left[\mathrm{HCO}_{3}^{-}\right] / \mathrm{K}_{1}} \\
& {\left[\mathrm{CO}_{3}{ }^{2-}\right]=\mathrm{K}_{2}\left[\mathrm{HCO}_{3}^{-}\right] /\left[\mathrm{H}^{+}\right]}
\end{aligned}
$$

The constants $\mathrm{K}_{1}$ and $\mathrm{K}_{2}$ are temperature-dependent constants that were derived using the Van't Hoff equation and measured temperatures from the field (Drever, 1997):

$$
\ln \mathrm{K}_{\mathrm{T} 2}=\ln \mathrm{K}_{\mathrm{T} 1}+\frac{\Delta \mathrm{H}_{\mathrm{R}}^{\circ}}{2.303 \mathrm{R}}\left(\frac{1}{\mathrm{~T}_{1}}+\frac{1}{\mathrm{~T}_{2}}\right)
$$

where $\mathrm{K}_{\mathrm{T} 1}$ is the constant at $25{ }^{\circ} \mathrm{C}$ (i.e. the reference temperature), $\mathrm{K}_{\mathrm{T} 2}$ is the constant of interest at the specified temperature, $\Delta \mathrm{H}_{\mathrm{R}}^{\circ}$ is the standard enthalpy of the reaction in $\mathrm{kJ} / \mathrm{mol}$ (i.e. tabulated value from Drever, 1997), $\mathrm{T}_{1}$ and $\mathrm{T}_{2}$ are temperatures in Kelvin at $25{ }^{\circ} \mathrm{C}$ and the measured temperature, respectively. Data can be found in the Appendix, Table 5.

DIC concentrations were not calculated for the shale gas drilling samples since $\mathrm{pH}$ measurements were not obtained and would not be representative of the groundwater itself. The waters were allowed to sit in the holding tanks for times ranging from days to 
a couple of weeks, thus $\mathrm{pH}$ measurements would not be true and the total DIC would subsequently be incorrect. 


\section{CHAPTER 4}

\subsection{Results and Discussion}

The complete data set used for this study can be found in the Appendix, Tables 16. A total of 25 water samples were analyzed for isotope compositions and additional geochemical proxies (Table 4.0). Samples were taken from natural springs, abandoned coal mine discharge and shale gas drilling produced waters. Specific results and interpretations are discussed below.

\subsection{Oxygen and Hydrogen Isotope Composition of Waters}

Specific values for $\delta^{18} \mathrm{O}_{\mathrm{H} 2 \mathrm{O}}$ and $\delta^{2} \mathrm{H}_{\mathrm{H} 2 \mathrm{O}}$ in natural springs ranged from -7.9 to -8.7 $\%$ and from -50.0 to $-57.4 \%$ VSMOW, respectively. The coal mine discharge water reported values ranged from -8.2 to $-8.5 \%$ and from -54.6 to $-56.6 \%$ VSMOW for $\delta^{18} \mathrm{O}_{\mathrm{H} 2 \mathrm{O}}$ and $\delta^{2} \mathrm{H}_{\mathrm{H} 2 \mathrm{O}}$, respectively. The shale gas drilling associated flowback waters show a very different isotopic composition of water. Values for $\delta^{18} \mathrm{O}_{\mathrm{H} 2 \mathrm{O}}$ range from -2.4 to -2.5 \% VSMOW and from -31.5 to $-38.8 \%$ VSMOW for $\delta^{2} \mathrm{H}_{\mathrm{H} 2 \mathrm{O}}$ (Appendix, Table 3). Precisions for the measured values were $\pm 0.06 \%$ for $\delta^{18} \mathrm{O}_{\mathrm{H} 2 \mathrm{O}}$ and $\pm 1 \%$ for $\delta^{2} \mathrm{H}_{\mathrm{H} 2 \mathrm{O}}$. All values measured for $\delta^{18} \mathrm{O}_{\mathrm{H} 2 \mathrm{O}}$ and $\delta^{2} \mathrm{H}_{\mathrm{H} 2 \mathrm{O}}$ for this study were plotted relative to the global meteoric water line (GMWL) and local meteoric water line (LMWL) (Fig. 4.0).

Oxygen and hydrogen are ideal tracers in hydrological studies since they form the water molecule itself. On a global scale the waters show an excellent correlation between the $\mathrm{O}$ and $\mathrm{H}$ isotopic composition, which defines the global meteoric water line (GMWL). Deviations from this GMWL exist due to variations in isotopic composition of 
the source vapor mass, temperature, humidity and evaporation resulting in Local Meteoric Water Lines (LMWL) with varying slopes and intercepts. The $\mathrm{O}$ and $\mathrm{H}$ isotopic composition of waters in different groundwater aquifers will primarily be dependent on the time and season of recharge, and water-rock interactions they have undergone (Fig. 2.4 and 2.7). These processes can impart a unique $\mathrm{O}$ and $\mathrm{H}$ isotopic signature to waters in different geochemical settings.

A regression line representing the local meteoric water line (LMWL) was constructed using the latitude, longitude and altitude of several groundwater wells in the area (Bowen et al., 2012). The equation obtained for the LMWL is:

$$
\delta^{2} \mathrm{H}=7.36^{*} \delta^{18} \mathrm{O}+7.22
$$

The equation for the LMWL correlates well with the GMWL equation of (Rosanski et al., 1993):

$$
\delta^{2} \mathrm{H}=8.13 * \delta^{18} \mathrm{O}+10.8
$$

Neither the slope nor y-intercept coefficients are truly constant values as they vary based on localized changes in atmospheric temperature and conditions. The LMWL has a slightly shallower slope and lower y-intercept than the GMWL. The slope of the line represents secondary evaporation effects during precipitation. The slope of the LMWL does not deviate greatly from the GMWL, indicating a small effect of evaporative enrichment in the geographic area. The y-intercept, also known as d-excess, corresponds to the relative humidity in the area and is assumed to be $85 \%$ for the GMWL. The lower d-excess of the LMWL can be attributed to an overall higher relative humidity (> $85 \%$ ) 
in the area. This would result in less of a degree of kinetic fractionation, thus decreasing the y-intercept (Fig. 2.4).

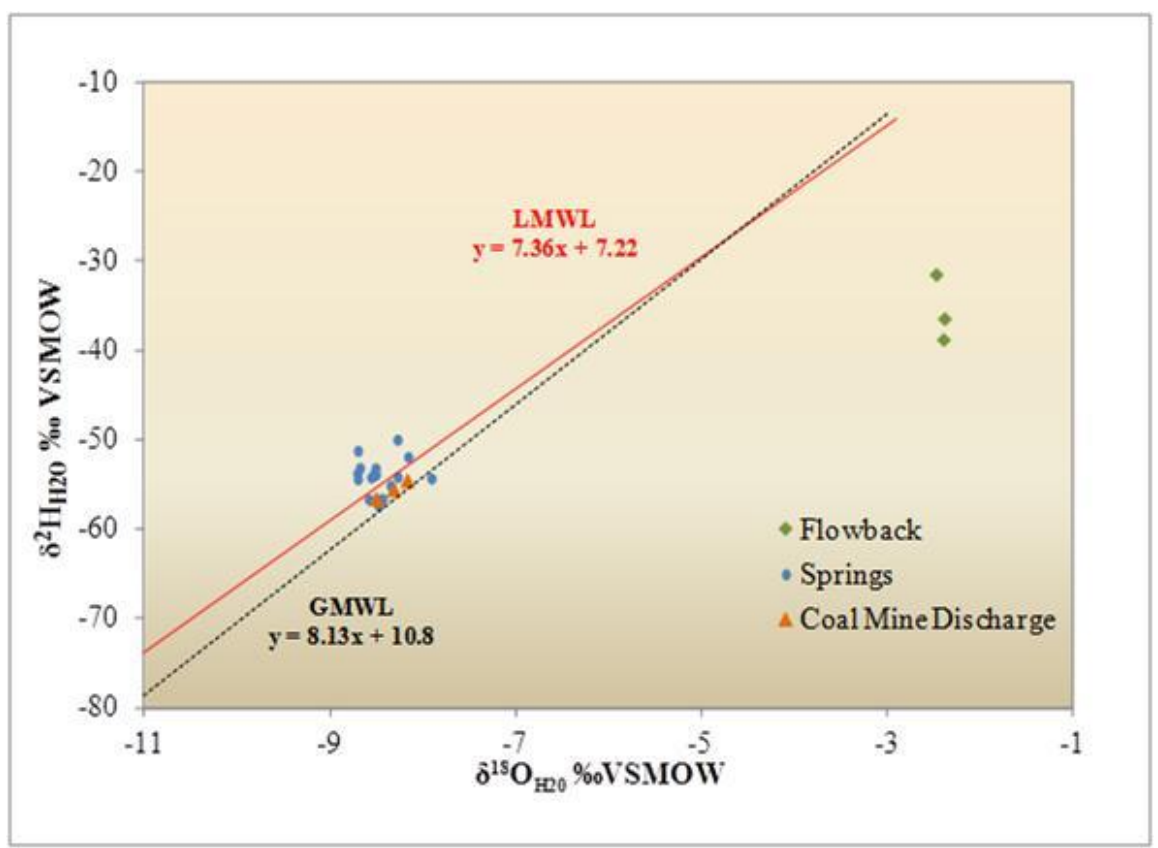

Figure 4.0 $-\delta^{18} O$ and $\delta^{2} H$ of samples plotted with the global meteoric water line $(G M W L)$ and derived local meteoric water line (LMWL). Samples for springs and coal mine discharge cluster around precipitation lines, while flowback waters are distinguishable and plot far to the right.

The term "meteoric water" refers to water in the ground that has originated from atmospheric sources and has gone through a portion(s) of the meteorological cycle (i.e. evaporation, condensation, precipitation). Since the isotopic values of the natural springs and coal mine discharge water cluster around the LMWL, this provides evidence that meteoric water is the prime source of recharge. These waters circulated through the geological formations and finally discharged to the surface. 


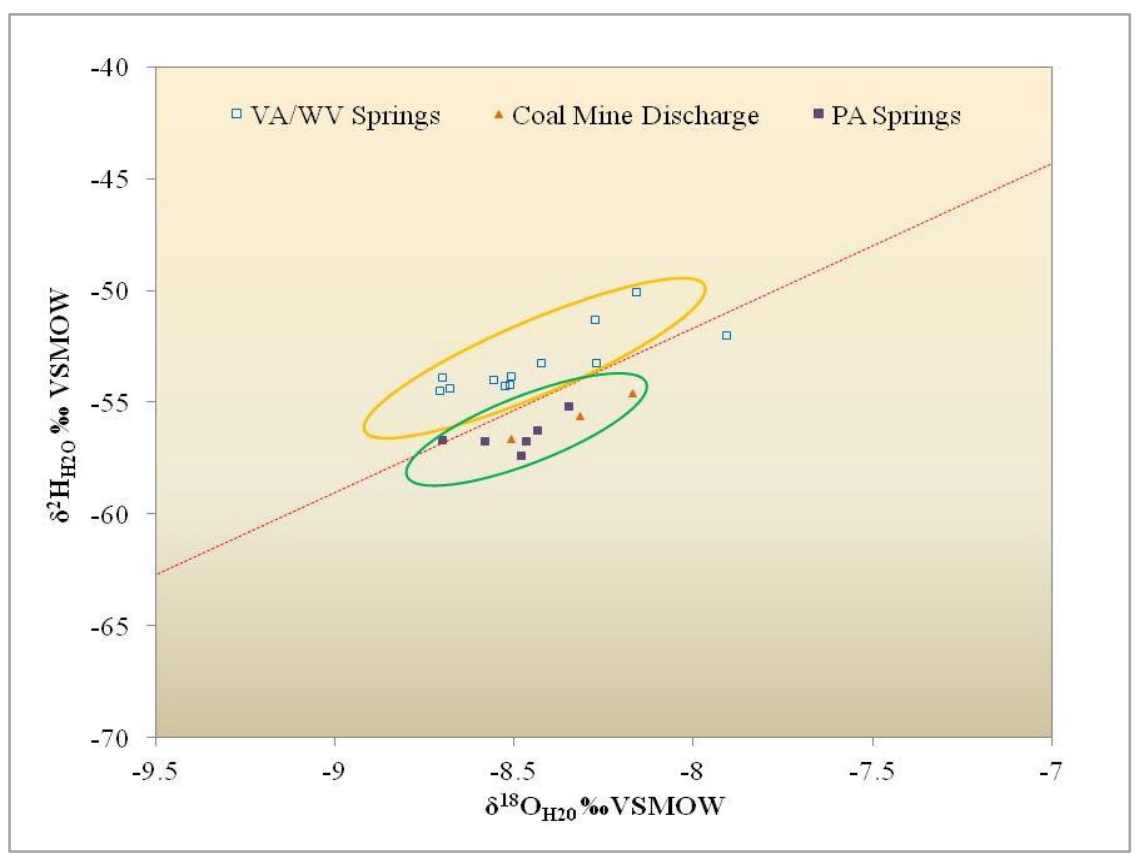

Figure 4.1 $-\delta^{18} O$ and $\delta^{2} H$ of springs and coal mine discharge (CMD) samples plotted with $L M W L$. Note, scale is zoomed in to accentuate minor differences. Springs in VA and WV plot slightly above the LMWL while CMD and springs in PA plot below.

Upon further investigation, regional differences in recharge sources and hydrological processes can be seen when zooming in on the clustered region (Fig. 4.1). All the values plotted below the LMWL are PA springs and coal mine discharge waters (with the exception of MAGNESIA spring in Virginia) and are enriched in ${ }^{18} \mathrm{O}$ compared to the ${ }^{2} \mathrm{H}$. This could indicate that waters in this study area are subjected to evaporative processes.

Regionally, spring waters from Pennsylvania and the coal mine discharge water are slightly more depleted in the heavy isotopes than the springs from southern West Virginia/Virginia area. Though the differences are intensified by the small scale, it is apparent that minor regional variations have an effect on stable isotope composition of water. The distance between the sites in both regions is $\sim 345 \mathrm{~km}$ and a difference of $\sim 3^{\circ}$ latitude. As explained by Dansgaard (1964), temperature is the main factor which 
controls the isotopic signature of precipitation since it dictates how much moisture a cloud mass can hold. With that in mind, it is expected that higher latitudes (cooler temperatures) will have more negative values. This is a direct result of the rain out effect in which the heavier isotopes are subsequently precipitated out as rainfall, leaving behind the lighter isotopes as a vapor mass travels to higher latitudes. Therefore, the slightly more depleted values of the springs and coal mine discharge waters in Pennsylvania $\left(\delta^{18} \mathrm{O}_{\mathrm{H} 2 \mathrm{O}}\right.$ average $\approx-8.4 \%$ and $\delta^{2} \mathrm{H}_{\mathrm{H} 2 \mathrm{O}}$ average $\approx-56.0 \%$ ) compared to the springs in southern WV/VA area $\left(\delta^{18} \mathrm{O}_{\mathrm{H} 2 \mathrm{O}}\right.$ average $\approx-8.3 \%$ and $\delta^{2} \mathrm{H}_{\mathrm{H} 2 \mathrm{O}}$ average $\approx-52.2 \%$ ) may be a result of regional differences in latitude and temperature. When compared to the expected $\delta^{18} \mathrm{O}_{\mathrm{H} 2 \mathrm{O}}$ and $\delta^{2} \mathrm{H}_{\mathrm{H} 2 \mathrm{O}}$ values determined from Bowen et al. (2012), the springs and coal mine discharge waters in Pennsylvania have expected values of -8.2 and $-53 \%$ VSMOW respectively while the springs from southern WV/VA region have expected values of -7.8 and $-50 \%$ VSMOW. These expected values are consistent with the measured values in this study in that the locations at higher latitudes exhibit slightly more depleted values. Furthermore, variations in the isotopic compositions of the springs could arise from different times of recharge, altitudes and proximity to the coast.

The $\delta^{18} \mathrm{O}_{\mathrm{H} 2 \mathrm{O}}$ and $\delta^{2} \mathrm{H}_{\mathrm{H} 2 \mathrm{O}}$ values of the flowback waters produced from shale gas drilling showed a much higher $\mathrm{O}$ and $\mathrm{H}$ signature

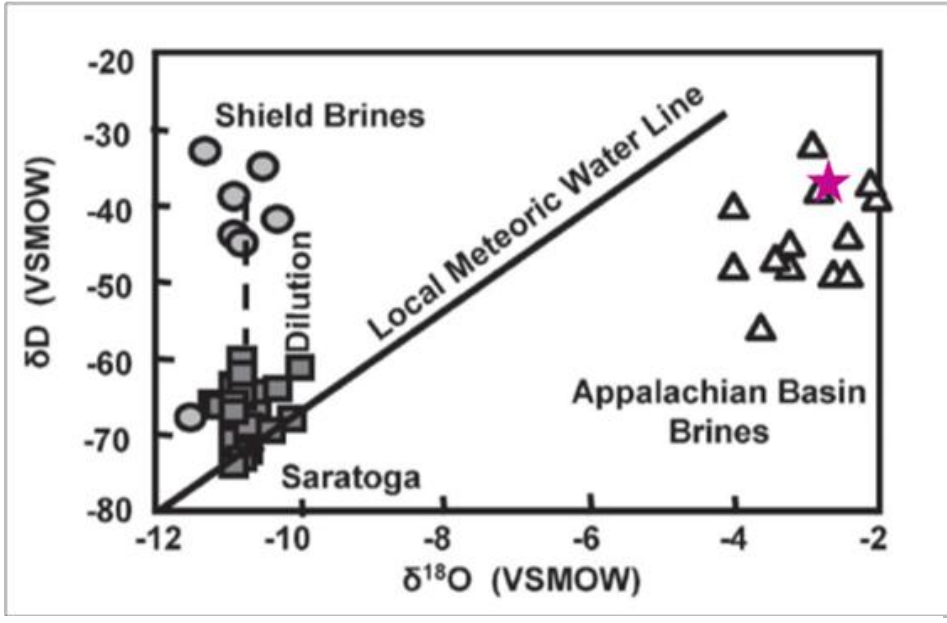

Figure 4.2-Comparison of collected flowback samples (indicated by the star) to published values for Appalachian brines (modified from Siegel et al., 2004). 
accompanied by a significant shift towards the right (Fig. 4.0). Values plotting right of the LMWL indicate large enrichments in ${ }^{18} \mathrm{O}$ and relatively small enrichments in ${ }^{2} \mathrm{H}$ compared to meteoric waters. These signatures are similar to the values published for Appalachian brines and Lower-Mid Devonian produced waters (Siegel et. al, 1990; Siegel et. al, 2004; Warner et. al, 2012; Wilson and Long, 1993) (Fig. 4.2). Spatial and temporal trends at this site are under further investigation.

The isotopic evolution of waters in brine-forming processes can be determined by varying trajectories from the GMWL and any secondary modifying processes (Horita, 2005) (Fig. 4.3). The solid lines on Figure 4.3 represent primary, brine-forming processes while the dashed lines represent secondary, modifying processes. The main processes which alter the isotopic signature of formation waters in sedimentary basins are isotopic exchange between water and formation minerals, evaporation and condensation, and

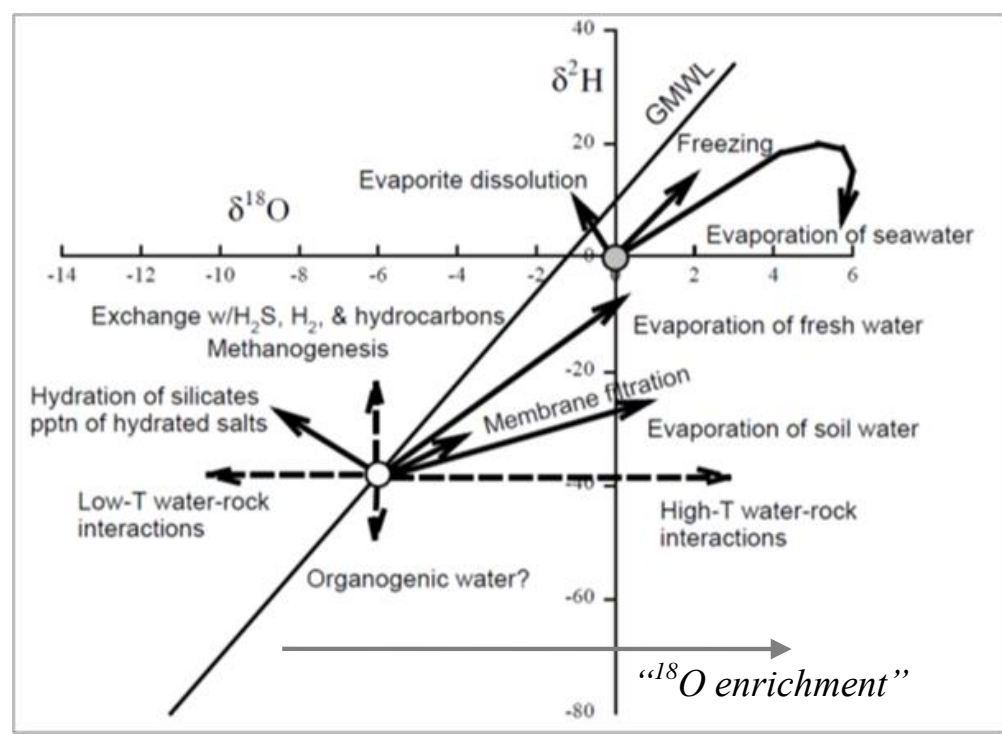

Figure 4.3-Schematic for the isotopic evolution of brines. Solid lines represent primary brine-forming processes and dashed lines represent secondary, modifying processes (modified from Horita, 2005). fractionation caused by membrane properties of formation rocks (Kharaka and Thordsen, 1992). The major sources of brine waters in sedimentary basins include; recent or old meteoric waters, diagenetically modified connate sea water, and metamorphic waters. Also, mixing of any combination of the three types could impart 
different isotope signatures of brine waters (Horita, 2005). The origin of brines in this study is probably from connate seawater which has been chemically and isotopically modified by evaporation and/or water-rock interactions within the sedimentary basin with the incorporation of meteoric water. These waters are characterized by high $\mathrm{Na}-\mathrm{Ca}-\mathrm{K}-\mathrm{Cl}$ concentrations and enriched isotope values (Appendix, Tables 3 and 4) (Horita, 2005; Siegel et al., 2004; Kesler et al., 1997). Similar enrichment trends have been reported in sedimentary basins worldwide and the ${ }^{18} \mathrm{O}$ enrichment in the formation fluids were attributed to exchange reactions with carbonate minerals. The exchange of deuterium is minimal since the amount of hydrogen-bearing minerals is relatively small in sedimentary rocks (Clayton, 1966; Kharaka and Thordsen, 1992).Water-rock interactions involving gypsum dehydration is another possible process which would result in enriched values of the formation water. Gypsum hydration water is enriched in ${ }^{18} \mathrm{O}$ relative to the seawater from which it precipitates, thus an input of water released during gypsum dehydration would shift the $\delta^{18} \mathrm{O}_{\mathrm{H} 2 \mathrm{O}}$ values toward the right (Wilson and Long, 1993). Graf et al. (1965) suggested that membrane filtration is also responsible for changes in the isotopic compositions. Membrane properties of shale formations have been found to impact the isotopic signatures of formation fluids. Coplen and Hanshaw (1973) discovered that lighter water molecules preferentially pass though a layer of shale under pressure, leaving behind waters enriched in ${ }^{18} \mathrm{O}$ and ${ }^{2} \mathrm{H}$. The magnitude and exact mechanics of this effect are relatively small and less understood than other mechanisms but is an additional process that could result in enriched values

Isotopic signatures of the sampled flowback waters could be a result of mixing between meteoric water used for hydraulic fracturing and formation brine. Surface water 
collected near the study area from Fish Creek in Marshall County, WV and waters used for hydraulic fracturing are plotted in Figure 4.4. It is hypothesized after cessation of hydraulic fracturing the percent contribution of frac water will decrease overtime and the flowback waters will acquire isotopic signature of the brine end-member. If this was the case, the flowback waters would plot along a mixing line, where the isotopic signatures of the flowback waters in the beginning stages would be closer to the signatures of surface waters used for hydraulic fracturing, and overtime the flowback waters would acquire a signature more representative of the brine end-member.

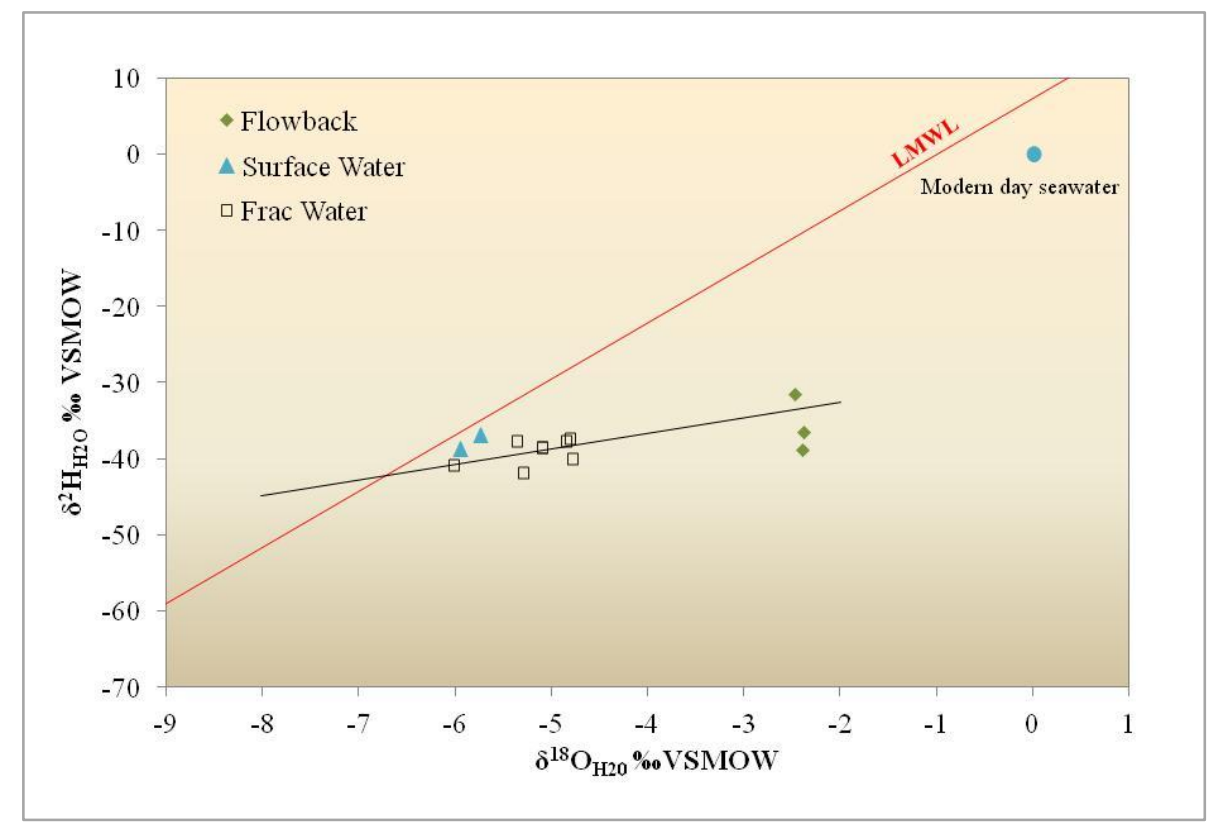

Figure 4.4-Isotopic composition of surface waters from Fish Creek (triangles) and water used for hydraulic fracturing (squares). The line represents a hypothetical mixing line between surface water and flowback water.

The individual processes and reactions cannot be distinguished based on the limited data available for this research. However, it is important to note that these unique $\mathrm{O}$ and $\mathrm{H}$ values of produced waters could potentially serve as natural fingerprints to identify groundwaters and surface waters that have received significant contribution from 
flowback waters due to improper water management practices, natural fracture/faults or leaky well casings.

\subsection{Carbon Isotope Composition of DIC}

In this study, the $\delta^{13} \mathrm{C}$ signatures of DIC were determined for each sampling location. The carbon isotopic composition of DIC shows a wide range of values from 16.2 to $25.3 \%$ VPDB (Appendix, Table 3). Specific values for natural spring samples in this study were taken at or near the point of discharge and $\delta^{13} \mathrm{C}_{\mathrm{DIC}}$ values range from -2.4 to $-16.2 \%$ VPDB. Coal mine drainage samples were taken directly out of the portal where the water was discharging from the abandoned mine (Fig. 1.1). The measured $\delta^{13} \mathrm{C}_{\text {DIC }}$ values were $-6.4,-9.0$ and $-10.2 \%$ VPDB. The $\delta^{13} \mathrm{C}_{\text {DIC }}$ values of the produced water samples collected from deep wells in the Marcellus shale are significantly different than other waters collected in this study. The isotopic signatures are much more positive and range from 21.9 to $25.3 \%$ VPDB. Precision for the measured values were $\pm 0.05 \%$ for $\delta^{13} \mathrm{C}_{\mathrm{DIC}}$. Data collected in this study are displayed on Figure 4.5. 


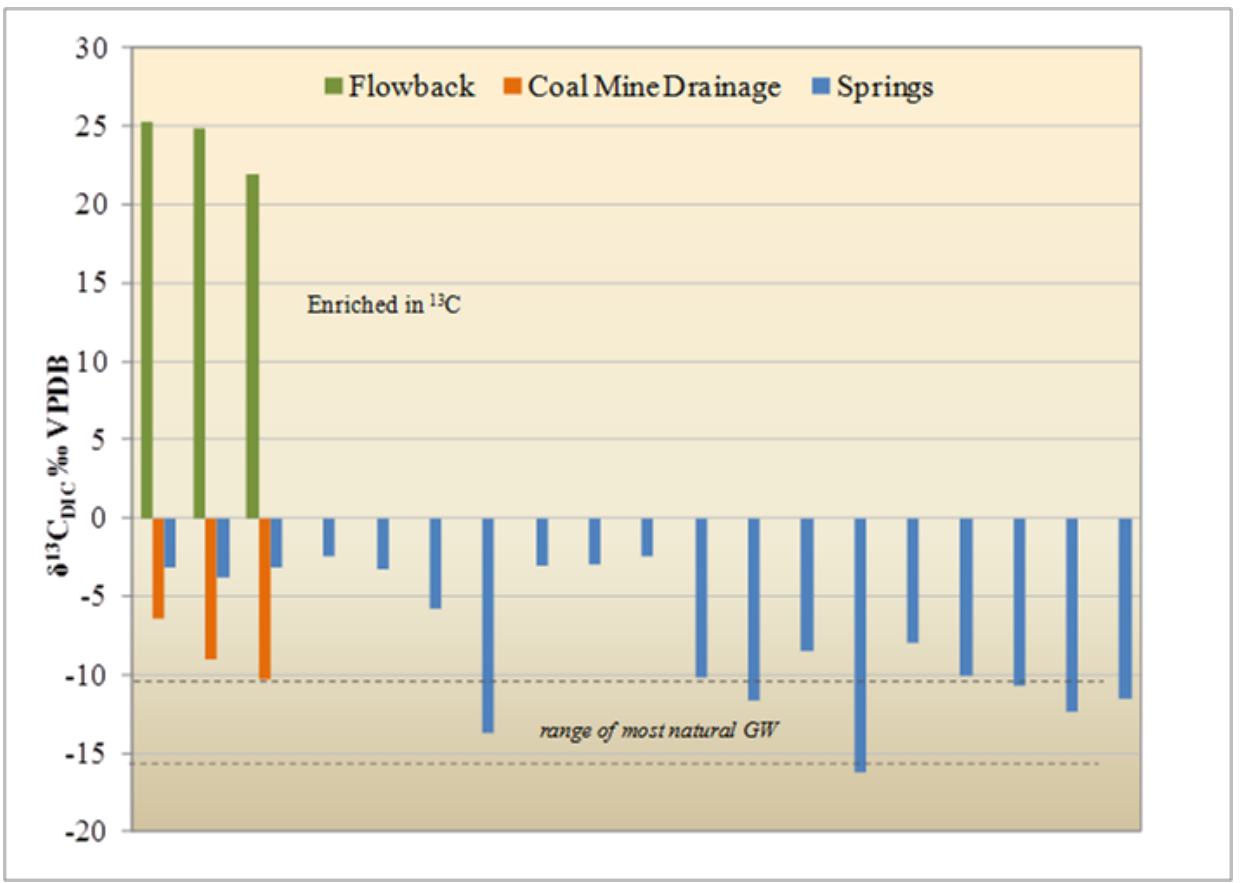

Figure 4.5- $\delta^{13} C_{D I C}$ of samples from this study. Spring and coal mine discharge samples are significantly different than enriched flowback samples. The dashed lines indicate the range of most natural groundwaters.

Stable carbon isotopes are useful indicators of sources of DIC since different geological materials retain different isotopic signatures. Understanding the role of carbon in our biosphere has many important environmental implications and stable isotopes of carbon provide a unique tool to explore the carbon cycle and its complex transformations throughout the environment.

In most natural waters, the primary sources of DIC are $\mathrm{CO}_{2}$-derived from decaying organic matter $(\approx-26 \%)$ and carbonate rock dissolution $(\sim+1 \%$ ) (Mook and Tan, 1991). Most normal groundwaters which receive equal contribution from both endmembers will have $\delta^{13} \mathrm{C}_{\text {DIC }}$ signatures ranging between -11 to $-16 \%$. Springs and coal mine discharge samples in this study have values ranging from -2.4 to $-16.2 \%$ VPDB, 
with $25 \%$ of these samples falling within the range for natural waters. Deviation from the natural ranges indicates a greater contribution from either end-member.

A majority of the spring samples $(79 \%)$ are more enriched in ${ }^{13} \mathrm{C}$ relative to the normal groundwater range, indicating a greater contribution from carbonate carbon. The measured $\delta^{13} \mathrm{C}_{\text {carbonate }}$ value of the rocks collected from the Silurian-Devonian group (Tonoloway and possibly the New Creek formations) in the region of the springs in southern West Virginia and southwest Virginia range from -5 to $-5.6 \%$ VPDB. The Pittsburgh formation limestone in the Pennsylvania springs region have a value similar to that of the carbonate at the coal mine drainage site ranging from -1.7 to $-2.6 \%$ VPDB (Appendix, Table 6). Neither of these end-members are as enriched in ${ }^{13} \mathrm{C}$ as predicted by equilibrium fractionation between calcite precipitating in equilibrium with oceanic bicarbonate between 15 and $20{ }^{\circ} \mathrm{C}$ (Table 2.0), but values can deviate from marine carbonate $(\sim 0 \%)$ by several permil $( \pm 5 \%)$ (Clark and Fritz, 1997). This indicates different sources of carbonate carbon, whose isotopic compositions are controlled by temperature, reactions with organic carbon and diagenetic fluids and re-crystallization. Figure 4.6 shows the variations in springs and coal mine discharge samples compared to their assumed carbonate end-members. Most Pennsylvania springs fall close to the range of normal groundwaters, with few samples slightly enriched in ${ }^{13} \mathrm{C}$. Out of 12 of the springs in WV and VA, only 3 are in or near the range of most natural groundwaters. These springs include Spellman Spring, Big Spring and Cold Magnesia, which are all cold springs with temperatures $<13.2{ }^{\circ} \mathrm{C}$. A majority of the springs in this region are enriched in ${ }^{13} \mathrm{C}$ relative to natural groundwaters and their carbonate end-member, assuming that these waters are in contact and reacting with these formations somewhere 
along their flowpaths. However, other contributing carbon sources (i.e. different carbonate units) and/or kinetically controlled fractionation processes may be occurring in these spring sites in WV and VA.

One possible explanation of this ${ }^{13} \mathrm{C}$ enrichment in the all spring waters is the isotope fractionation due to $\mathrm{CO}_{2}$ outgassing. The $\mathrm{CO}_{2}$ will diffuse out of the waters when concentrations are higher than atmospheric concentrations. The lightest species of the total DIC is $\mathrm{CO}_{2}$, thus degassing of $\mathrm{CO}_{2}$ to the atmosphere results in a shift in the

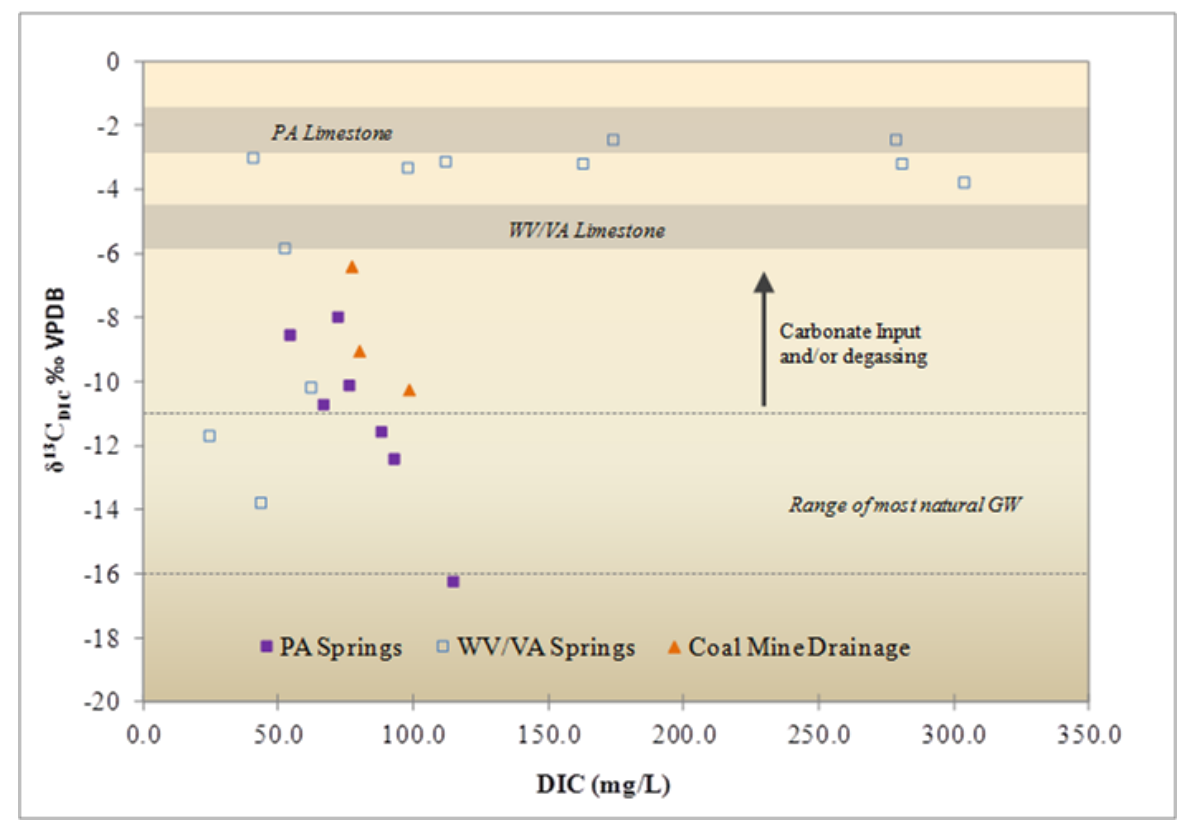

Figure 4.6-Variations in $\delta^{13} C_{D I C}$ for spring and CMD samples compared to their assumed carbonate end-members. Most samples are more enriched in ${ }^{13} \mathrm{C}$ relative to most natural groundwaters, indicating a greater contribution from carbonate carbon and/or degassing.

remaining DIC to more enriched values. Many of the springs in WV and VA have $\mathrm{P}_{\mathrm{CO} 2}$ values higher than that of atmospheric and there is visual evidence of air/gas bubbling out of the water (Moore, 2012). In many of the PA springs, the exact discharge location could not be found, thus exposing waters to atmospheric conditions. Additionally, the springs in PA are all associated with tufa formations which are formed by the degassing of $\mathrm{CO}_{2}$-rich 
groundwater (Hendy, 1971; Pentecost, 2005). Therefore, the enrichment in ${ }^{13} \mathrm{C}$ in all the springs is likely a combination of a greater input from carbonate carbon and $\mathrm{CO}_{2}$ degassing. Similar results have been found in Sharma et al. (unpublished, 2012), Doctor et al. (2008) and Andrews (2006). Enriched carbon isotope values in the springs in WV and VA could be a result of interactions with isotopically enriched calcite cements in fractures or at depth, reactions with other carbonate units, degassing of $\mathrm{CO}_{2}$ at the surface, or could originate from mantle $\mathrm{CO}_{2}$ or an igneous melt source which has typical values of $\delta^{13} \mathrm{C}$ in the range of $\sim 0$ to $-4 \%$ (Siegel et al., 2004; Clark and Fritz, 1997). Helium isotope ratios can be used in conjunction with carbon isotopes of $\mathrm{CO}_{2}$ gas to confirm the incorporation of mantle derived $\mathrm{CO}_{2}$ since atmospheric, crustal and mantle He ratios are all different (Du et al., 2006; Siegel et al., 2004).

Typically, increased $\mathrm{Ca}$ concentrations support the processes of carbonate dissolution which adds heavier carbon $\left({ }^{13} \mathrm{C}\right)$ to the total DIC. The Ca concentrations in all the springs range from 29.1 to $295.1 \mathrm{mg} / \mathrm{L}$ (Appendix, Table 4). If dissolution of carbonates is the main source of carbon to the system it should be accompanied by an increase in $\mathrm{Ca}$ and $\mathrm{HCO}_{3}{ }^{-}$concentrations accompanied by a shift to more positive values of $\delta^{13} \mathrm{C}_{\mathrm{DIC}}$. To further investigate these trends, the springs in WV and VA were divided into two groups; Old Sweet Spring and Sweet Chalybeate Spring samples, and all other springs in Virginia. These springs were divided based on their geographic locations where Old Sweet Spring and Sweet Chalybeate Spring samples are closer in proximity to each other compared to the rest of the springs in the southern sampling region. Additionally, Old Sweet Spring and Sweet Chalybeate Spring samples displayed significantly higher cation and anion concentrations (Appendix, Table 4) (Moore, 2012). 
Figure 4.7 confirms the relationship stated above where increased carbonate dissolution (supported by increased $\mathrm{Ca}$ and $\mathrm{HCO}_{3}{ }^{-}$concentrations) correspond to more positive values of $\delta^{13} \mathrm{C}_{\text {DIC. }}$. Variations in $\delta^{13} \mathrm{C}_{\text {DIC }}$ among different springs could be a result of the processes above, or a combination of processes. In either case, the distinct signatures can be used as tracers to help determine sources, chemical reactions and interactions.

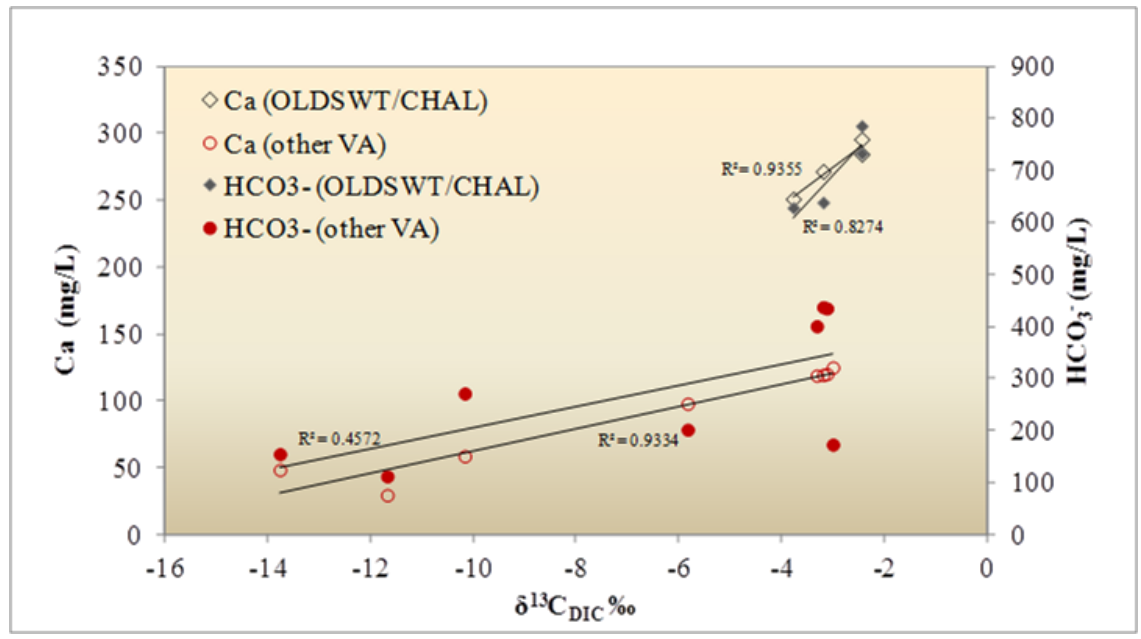

Figure 4.7-Relationship of $\mathrm{Ca}^{2+}$ and $\mathrm{HCO}_{3}^{-}$concentrations to $\delta^{13} \mathrm{C}_{D I C}$ in springs sampled in VA and WV. Note the positive correlation as evidence of carbonate dissolution.

The coal mine discharge samples also suggest a greater contribution from the carbonate end-member since their reported values are more enriched in ${ }^{13} \mathrm{C}$ relative to the normal range of groundwaters (Fig. 4.6). Potential sources of carbon to the total DIC pool in this system include $\mathrm{HCO}_{3}{ }^{-}$that originates from the dissolution of carbonates by dissolved $\mathrm{CO}_{2}$, and/or by sulfuric acid produced as a by-product of pyrite oxidation in coal mines. It is hypothesized that sulfuric acid enhanced weathering is responsible for the release of old carbon stored as $\mathrm{CaCO}_{3}$. Sulfuric acid-enhanced weathering of carbonate minerals proceeds by the following reaction:

$$
8 \mathrm{H}_{2} \mathrm{SO}_{4}+16 \mathrm{CaCO}_{3} \rightarrow 8 \mathrm{SO}_{4}{ }^{2-}+16 \mathrm{HCO}_{3}^{-}+16 \mathrm{Ca}^{2+}
$$


Excess sulfur produced by the oxidation of pyrite in a coal mine environment creates sulfuric acid (Eqs. 2.12 and 2.13) which weathers $\mathrm{CaCO}_{3}$. Weathering by carbonic acid on the other hand occurs by the reaction:

$$
\mathrm{CaCO}_{3}+\mathrm{H}_{2} \mathrm{O}+\mathrm{CO}_{2} \rightarrow \mathrm{Ca}^{2+}+2 \mathrm{HCO}_{3}^{-}
$$

Both reactions (Eqs. 4.2 and 4.3) will produce $\mathrm{HCO}_{3}{ }^{-}$isotopic signatures similar to the carbonate mineral being dissolved, but may yield different $\delta^{13} \mathrm{C}_{\mathrm{DIC}}$, depending on the contributing end-members. For example, weathering by carbonic acid (Eq. 4.3), consumes atmospheric $\mathrm{CO}_{2}\left(\delta^{13} \mathrm{C} \approx-8 \%\right)$ and only half of the total DIC released is from older carbon, whereas all of the DIC released by sulfuric acid weathering (Eq. 4.2) is older carbon. This results in a larger net release of old carbon bound up as $\mathrm{CaCO}_{3}$ which has an isotopic signature of $\sim 0 \% \pm 2 \%$.

A two end-member mixing model was used to estimate the total amount of carbon which originated as carbonate carbon. If it is assumed that the carbon is being contributed by oxidation of organic matter and carbonate dissolution, a mixing model can be used to calculate the fraction of carbon being contributed from each end-member by the following equation:

$$
\delta^{13} \mathrm{C}_{\text {mix }}=\delta^{13} \mathrm{C}_{\text {carbonate }} \mathrm{f}_{1}+\delta^{13} \mathrm{C}_{\text {organic }}\left(1-\mathrm{f}_{1}\right)
$$

where $\delta^{13} \mathrm{C}_{\text {mix }}$ represents the isotopic signature of the DIC in the water sample and $\mathrm{f}_{1}$ is the fraction from carbonate dissolution. The measured $\delta^{13} \mathrm{C}_{\text {carbonate value of the Pittsburgh }}$ formation limestone in the study area was $-2.5 \%$ VPDB. The other end-member, which represented the organic matter, was $\delta^{13} \mathrm{C}_{\text {organic }}=-24.3 \%$ VPDB. Therefore, the greater 
contribution from the carbonate end-member

would result in the $\delta^{13} \mathrm{C}_{\mathrm{DIC}}$ more enriched in

${ }^{13} \mathrm{C}$ than most groundwaters in the region (Fig.

4.6).

\begin{tabular}{|cc|}
\hline $\boldsymbol{\delta}^{13} \mathbf{C}_{\text {DIC }}$ V-PDB & $\begin{array}{r}\text { Fraction from } \\
\text { carbonate (\%) }\end{array}$ \\
\hline-6.4 & 82 \\
-9.0 & 70 \\
-10.2 & 65 \\
\hline
\end{tabular}

Table 4.0-Calculated percent carbonate carbon from two end-member mixing

In all three sampling points, the percent model.

contribution from the carbonate end-member was greater than $50 \%$ (Table 4.0), indicating that carbonate dissolution is the dominant source of carbon to the total DIC. Mulder (2012) reported values for Pennsylvanian aquifers in the region which were not impacted by coal mine discharge. In comparison to Pennsylvanian aquifers in the region, $\delta^{13} \mathrm{C}_{\mathrm{DIC}}$ values of samples collected at this site were much more enriched in ${ }^{13} \mathrm{C}$, further

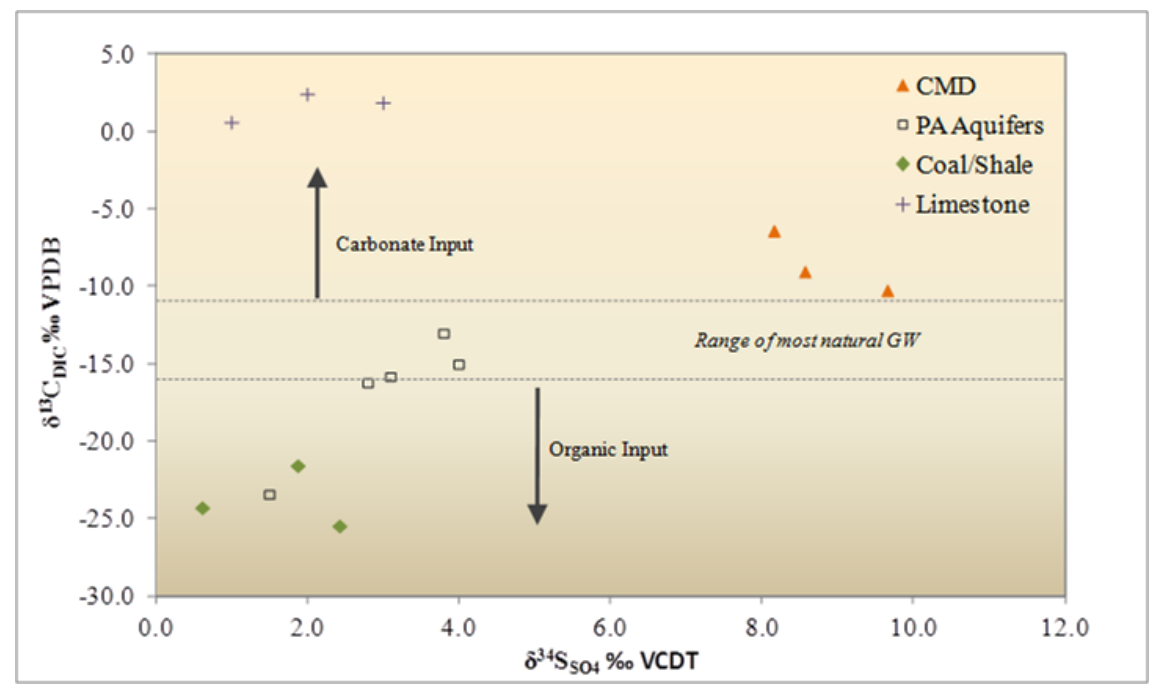

Figure 4.8 - $\delta^{13} C_{D I C} v s . \delta^{34} S_{S O 4}$ for coal mine drainage samples, Pennsylvanian age aquifers, coal/shales and limestone in the region. CMD samples are more enriched in ${ }^{13} \mathrm{C}$ relative to normal $P A$ aquifers, thus supporting a greater contribution of old carbonate carbon to the system.

supporting that waters discharging from mine portals receive a significant contribution from the carbonate end-member (Fig 4.8).

As in the natural spring sites, enhanced carbonate mineral dissolution is generally accompanied by an increase in $\mathrm{Ca}$ and $\mathrm{HCO}_{3}{ }^{-}$concentrations. If carbonate dissolution is 
the dominant source of carbon to the system, the increase in $\delta^{13} \mathrm{C}_{\mathrm{DIC}}$ signatures should be associated with an increase in $\mathrm{Ca}$ concentrations. However, we see an indirect relationship between $\delta^{13} \mathrm{C}_{\text {DIC }}$ signatures and $\mathrm{Ca}^{2+}$ concentrations (Fig. 4.9). One possible explanation for this relationship is the effect of cation-exchange processes on clay surfaces. Research by Capo et al. (2001) has indicated that the dominant cation exchange process in this region likely involves cation-exchange between $\mathrm{Ca}^{2+} / \mathrm{Mg}^{2+}$ and $\mathrm{Na}^{+}$in the overburden shales containing clay minerals. Equation 4.5 describes the exchange equilibrium between two divalent cations where two $\mathrm{Na}$ ions on exchange sites on clay are replaced by one $\mathrm{Ca}$ or $\mathrm{Mg}$ ion:

$$
2 \mathrm{Na}-\mathrm{EX}+\mathrm{Ca}^{2+} \leftrightarrow \mathrm{Ca}-\mathrm{EX}+2 \mathrm{Na}^{+}
$$

As a result of this process, free calcium and magnesium is bound up and removed from solution. If $\mathrm{Ca}$ or $\mathrm{Mg}$ is removed from the solution, the remaining water will remain under-saturated with respect to calcite. This relationship could drive further carbonate mineral dissolution which would also consequently increase the alkalinity. We would also expect a corresponding increase in $\mathrm{Na}$ concentrations if this was a major process, which is not the case (Appendix, Table 4) (Fig. 4.9). This process may be occurring to a certain degree at this site but our data does not support the process of cation exchange of $\mathrm{Na}$ for $\mathrm{Ca} / \mathrm{Mg}$. 


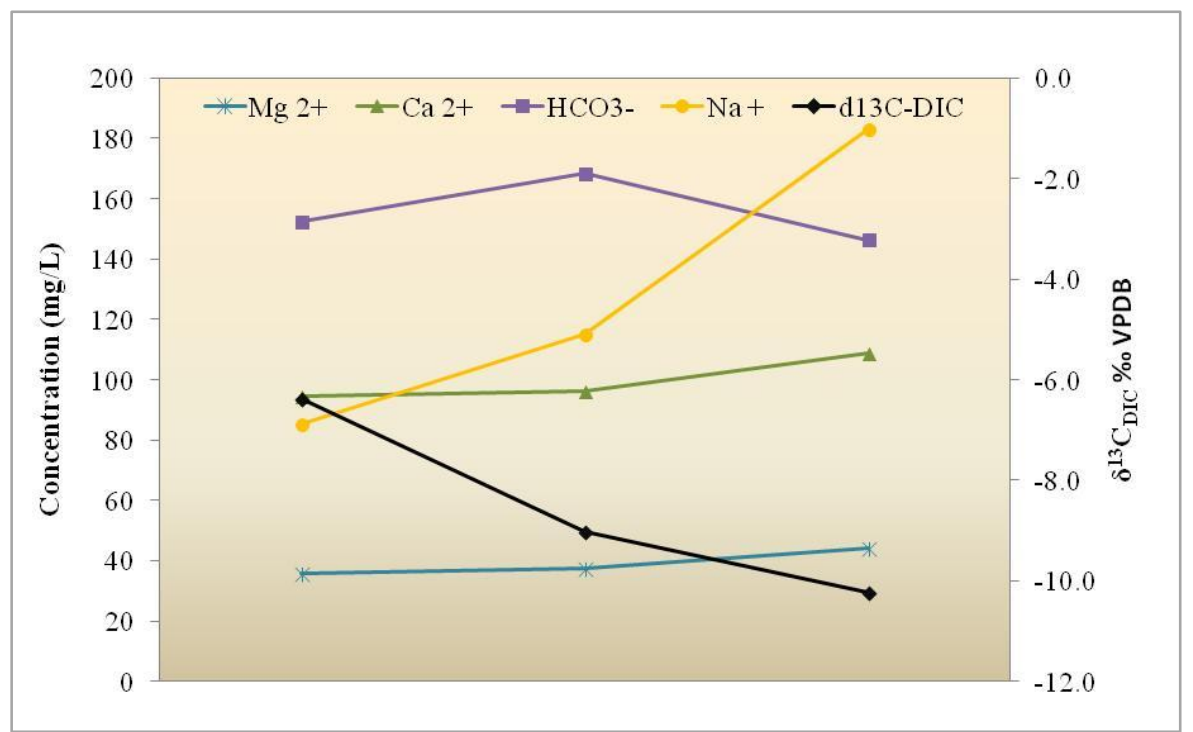

Figure 4.9-Cation and bicarbonate concentrations compared to $\delta^{13} C_{D I C}$ for $C M D$ site. Data does not support the process of cation exchange.

The flowback waters have very high $\delta^{13} \mathrm{C}_{\text {DIC }}$ values in the range of +10 to $+30 \%$ VPDB. Such high $\delta^{13} \mathrm{C}_{\text {DIC }}$ are representative of organic-rich systems where bacterial processes, such as methanogenesis, preferentially remove the lighter carbon $\left({ }^{12} \mathrm{C}\right)$ to produce methane and contribute heavy carbon $\left({ }^{13} \mathrm{C}\right)$ to the remaining DIC pool (Whiticar et. al, 1986; Simpkins et. al, 1993; Cheung et al., 2010; Laughrey and Baldassare, 1998; Börjesson et al, 1997; Sharma and Frost, 2008; Atekwana, 1996). Biogenic methane is produced as a byproduct of bacterial reduction of organic carbon by two major pathways; $\mathrm{CO}_{2}$ reduction and acetate fermentation, shown below (Eqs. 4.6 and 4.7). The pathway of $\mathrm{CO}_{2}$ reduction is less significant in freshwater systems while acetate fermentation is responsible for $\sim 70 \%$ of methanogenesis occurring in freshwater (Whiticar, 1999).

$$
\begin{array}{lll}
\mathrm{CO}_{2}+8 \mathrm{H}^{+}+8 \mathrm{e}^{-} \rightarrow \mathrm{CH}_{4}+2 \mathrm{H}_{2} \mathrm{O} & \left(\mathrm{CO}_{2}\right. \text { Reduction) } \\
\mathrm{CH}_{3} \mathrm{COOH} \rightarrow \mathrm{CH}_{4}+\mathrm{CO}_{2} & \text { (Acetate Fermentation) }
\end{array}
$$


Additionally, quantitative PCR analyses supported the existence of Methanosarcinales sp., which is a species of methanogenic bacteria that uses various substrates such as methanol, methylamines, $\mathrm{H}_{2}$ and acetate as organic substrates to produce methane (Sharma et al., unpublished). Produced gas samples from 5 Marcellus wells at this site have $\delta^{13} \mathrm{C}_{\mathrm{CH} 4}$ and $\delta^{2} \mathrm{H}_{\mathrm{CH} 4}$ values of produced gas of $-37.7 \pm 0.5 \%$ and $165.6 \pm 0.9 \%$ respectively (Sharma et al., unpublished) indicating thermogenic origin of the gas, thus disproving the presence of biogenic methane supported by the $\delta^{13} \mathrm{C}_{\mathrm{DIC}}$ signatures. This may indicate that biogenic methanogenesis significantly altered the $\delta^{13} \mathrm{C}_{\mathrm{DIC}}$ signatures, but the contribution of biogenic fraction of the total gas produced by the reservoir was not significant enough to shift the $\mathrm{C}$ and $\mathrm{H}$ isotopic signature of total produced gas (Sharma et. al., unpublished data).

The preliminary $\delta^{13} \mathrm{C}_{\mathrm{DIC}}$ data indicates that the produced waters in the study area can be distinguished from ambient groundwaters by their very positive $\delta^{13} \mathrm{C}_{\mathrm{DIC}}$. For this reason, this unique isotopic signature can be used to track these waters in groundwater aquifers and surface waters in the region (Fig. 4.5). Further ongoing studies by Dr. Sharma's research group are trying to better understand the spatial and temporal changes in carbon isotope signatures.

\subsection{Sulfur and Oxygen Isotope Composition of Dissolved Sulfate}

The $\delta^{34} \mathrm{~S}_{\mathrm{SO} 4}$ of the springs and coal mine discharge show a wide range from 0.2 to $40.4 \%$ VCDT and the $\delta^{18} \mathrm{O}_{\mathrm{SO} 4}$ values range from 1.1 to $15.3 \%$ VSMOW (Appendix, Table 3). Specific values for $\mathrm{S}$ and $\mathrm{O}$ isotopes in the coal mine discharge site are 8.2, 8.6 
and $9.7 \%$ VCDT for sulfur and 4.0, 4.4 and 5.1 \% VSMOW for oxygen. Sulfate isotopes were not analyzed for flowback waters in this study.

Sulfur and oxygen isotopes can aid in distinguishing source of sulfate and biochemical processes that affect the $\delta^{13} \mathrm{C}_{\text {DIC }}$ discussed above. The most important kinetic sulfur isotope fractionation is between oxidized sulfur $\left(\mathrm{SO}_{4}{ }^{2-}\right)$ and reduced sulfur $\left(\mathrm{H}_{2} \mathrm{~S}\right)$. Bacteria often use ${ }^{32} \mathrm{~S}$ as an electron acceptor/oxidant in the degradation of organic matter by the following equation:

$$
2 \mathrm{CH}_{2} \mathrm{O}+\mathrm{SO}_{4}{ }^{2-} \rightarrow \mathrm{H}_{2} \mathrm{~S}+2 \mathrm{HCO}_{3}{ }^{-}
$$

Carbon from organic matter is incorporated into the total DIC resulting in lower $\delta^{13} \mathrm{C}_{\text {DIC }}$ values. Microbial sulfate reduction (Eq. 4.8) results in reduced sulfur compounds $\left(\mathrm{H}_{2} \mathrm{~S}\right)$ which can then be utilized by sulfur-oxidizing bacteria to generate sulfuric acid. This could in turn promote carbonate rock dissolution, thus adding more enriched carbonate carbon to the total DIC pool. Therefore $\delta^{13} \mathrm{C}_{\text {DIC }}$ can be used together with other isotopes to evaluate the presence and extent of biogeochemical reactions.

The $\delta^{34} \mathrm{~S}_{\mathrm{SO} 4}$ values of waters are plotted against sulfate concentrations (Fig. 4.10). With the exception of one spring in Virginia (MAGCOLD), the samples for the springs in WV/VA cluster around +30 to $+40 \%$ while the springs in PA and coal mine drainage site are more depleted and are concentrated around 0 to $+9 \%$. The fact that the $\delta^{34} \mathrm{~S}_{\mathrm{SO} 4}$ values of the springs in WV/VA vary within a narrow range and the springs in PA (including the coal mine discharge site) vary within a narrow range both independent of sulfate concentrations, indicate that the waters have different sources of sulfate. Furthermore, a plot of $\delta^{18} \mathrm{O}_{\mathrm{SO} 4}$ versus $\delta^{34} \mathrm{~S}_{\mathrm{SO} 4}$ with boundaries from Krouse and Mayer 


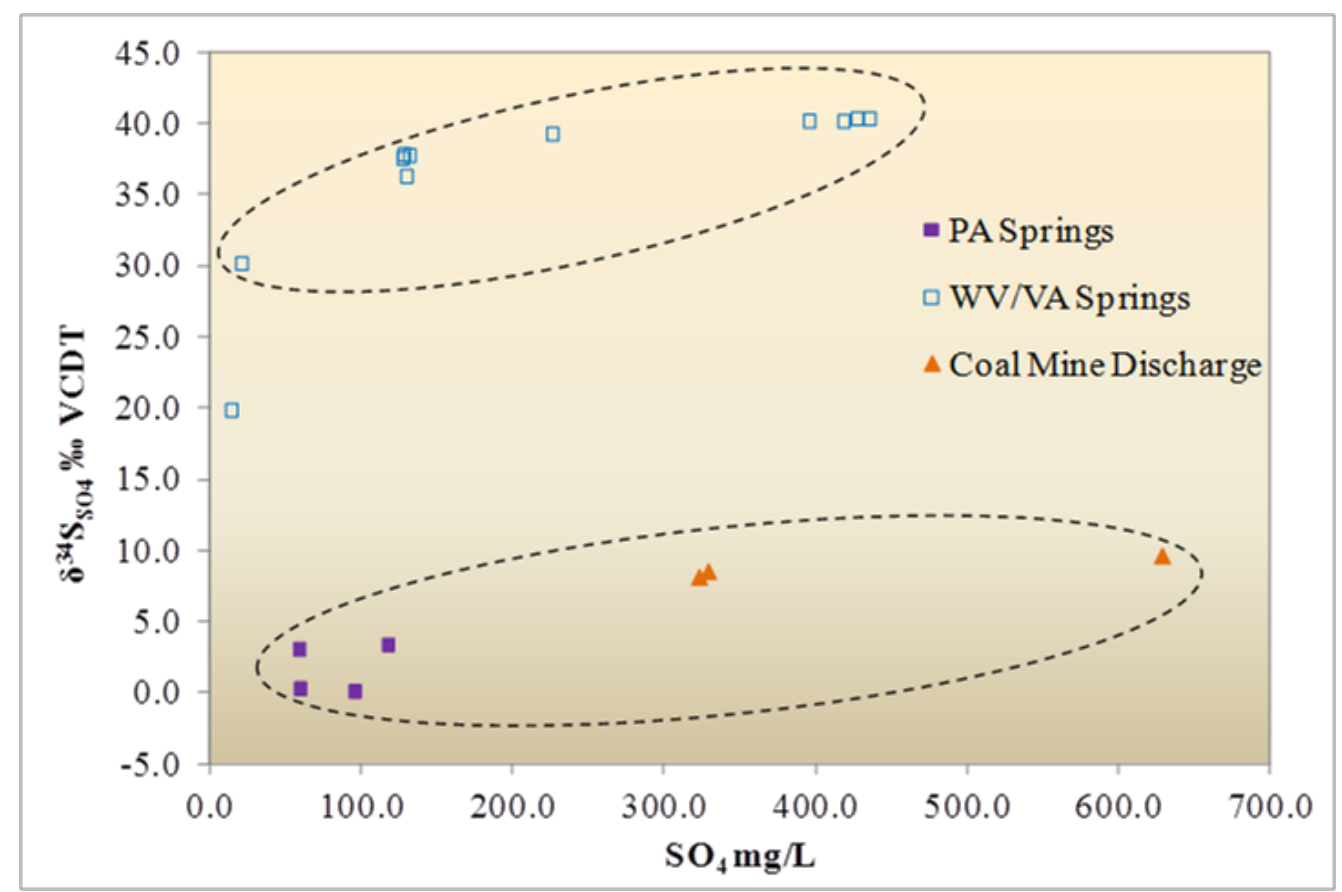

Figure 4.10- $\delta^{34} S_{S O 4}$ values of springs and CMD plotted versus sulfate concentrations. Despite the variations in concentrations, $\delta^{34} S_{S O 4}$ value cluster within a narrow range (dashed ovals).

(1996) also illustrate the different sources of sulfate in the sampled waters (Fig. 4.11). Sources of sulfate in these systems could be derived from dissolution of sulfate minerals (i.e. gypsum and anhydrite), oxidation of sulfide (i.e. pyrite), and biological activity.

In the Pennsylvania spring region, coals and shales containing pyrite are in abundance. The measured $\delta^{34} \mathrm{~S}$ values of pyrite in coal and shale in the region ranged from +0.6 to $+2.4 \%$ VCDT (Appendix, Table 6). The sampled springs in this region fall very close to or within this range $(0.2$ to $3.4 \%$ ) indicating that the dissolved sulfate originated from the oxidation of pyrite in this area. The coal mine discharge data show $\delta^{34} \mathrm{~S}_{\mathrm{SO} 4}$ and $\delta^{18} \mathrm{O}_{\mathrm{SO} 4}$ values more enriched than the springs in the similar region. These enriched values are hypothesized to be a product of a certain degree of sulfate reduction occurring along the flow-path in the abandoned mine. Sulfate anions are of abundant in the mine (concentrations ranging from 322.4 to $628.0 \mathrm{mg} / \mathrm{L}$ ) thus meeting one of the 


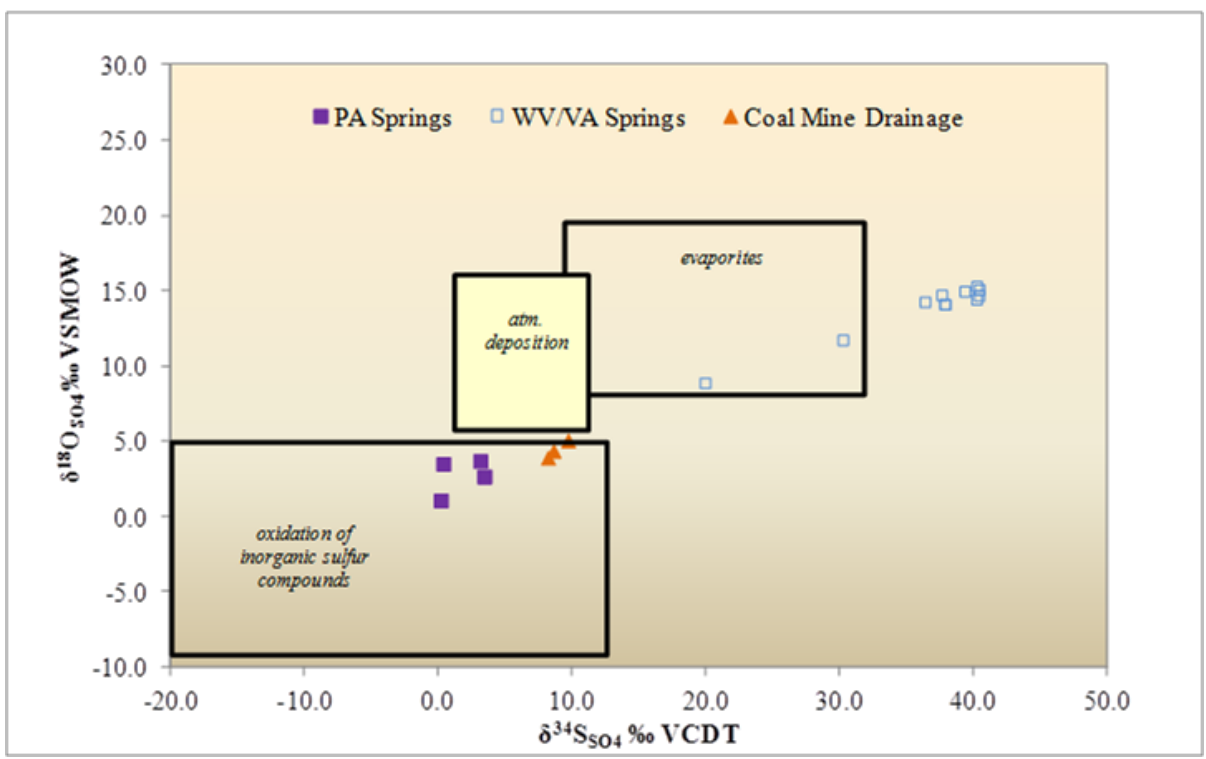

Figure 4.11- $\delta^{18} \mathrm{O}_{\mathrm{SO} 4}$ vs. $\delta^{34} S_{\mathrm{SO} 4}$ values of springs and CMD sites. Different sources of sulfate are seen between PA Springs/CMD site and other springs. Boundaries taken from Krouse and Mayer, 2000.

conditions necessary for biogenic sulfate reduction, along with anoxic environments, usable organic matter and near neutral conditions (Seal, 2003). Since greater than $50 \%$ of the carbon was determined to come from old carbonate carbon (Table 4.0), the depleted carbon which should be added to the total DIC as a result of sulfate reduction could be overwhelmed by the amount of carbon contributed to the total DIC from carbonate carbon.

If the dissolved sulfate in this system originated from the oxidation of pyrite (Eqs. 2.12 and 2.13), the $\delta^{34} \mathrm{~S}_{\mathrm{SO} 4}$ should be similar to the original sulfur source since there is negligible isotopic fractionation involved during the oxidation of dissolved sulfide (Clark and Fritz, 1997; Toran and Harris, 1989; Seal, 2006, Seal, 2003). The $\delta^{34} \mathrm{~S}_{\mathrm{SO}}$ values in groundwater samples collected from Pennsylvanian age aquifers of the region ranged from -0.4 to $+4.0 \%$ VCDT, which is similar to the S isotope values of the coals and shales of the area (Fig. 4.8) (Mulder, 2012). However, the isotopic values of $\delta^{34} \mathrm{~S}_{\mathrm{SO} 4}$ in the 
coal-mine water samples collected for the study were much more enriched in ${ }^{34} \mathrm{~S}$ and ${ }^{18} \mathrm{O}$, further supporting the fact that bacterially-mediated sulfate reduction could be occurring within anaerobic regions of the mine.

The springs in the WV/VA have isotopic values ranging from 19.9 to $40.4 \%$ VCDT for S and 8.9 to $15.3 \%$ VSMOW for O (Appendix, Table 3). The source of sulfate in these waters is most likely from dissolution of evaporite minerals (Fig. 4.11). There is no fractionation involved with dissolution of minerals hence its relationship to the source (Krouse and Mayer, 2000). The $\delta^{34} \mathrm{~S}_{\mathrm{SO} 4}$ values are slightly enriched in ${ }^{34} \mathrm{~S}$ compared to the evaporite sulfate source. High concentrations of dissolved sulfate are evident in all but 3 springs in this region (Appendix, Table 4). The springs which have low concentrations of sulfate (5.9, 13.5 and $20.3 \mathrm{mg} / \mathrm{L})$ include Big Spring, Magnesia Cold and Spellman which are all cold springs with temperatures $<20^{\circ} \mathrm{C}$ and fall within the region of evaporite sulfate (with the exception of VABIG which was not analyzed for $\mathrm{S}$ isotopes). Evaporite sulfates are the most soluble and thus most readily available form of sedimentary sulfur compounds (Krouse and Mayer, 2000). Claypool (1980) describes the isotopic composition of sulfate in marine evaporite deposited throughout the Earth's history. Variations in $\delta^{34} \mathrm{~S}$ values ranged from $+10 \%$ to a maximum of $+35 \%$ in the Cambrian era. The $\delta^{34} \mathrm{~S}$ values for Silurian-Devonian and Ordovician aged evaporites are in the range of +25 to $+30 \%$ (Claypool et al., 1980, Krouse and Mayer, 2000). The $\delta^{34} \mathrm{~S}_{\text {SO4 }}$ values for the springs in WV and VA are slightly more enriched in ${ }^{34} \mathrm{~S}$ than the expected values therefore suggesting additional processes may be occurring to enrich these values. Bacterial sulfate reduction is one process which may be taking place to a certain extent in some of these springs to enrich $\mathrm{S}$ values beyond the isotopic composition 
of the source. As discussed in the coal mine drainage waters, bacterially-mediated sulfate reduction will result in more enriched residual sulfate since the sulfate-reducing bacteria preferentially incorporate the lighter $\left({ }^{32} \mathrm{~S}\right)$ sulfur through the processes of organic matter degradation (Eq. 4.8).

The stable isotopes of sulfate ( $\mathrm{S}$ and $\mathrm{O}$ ) provide evidence of different sources of sulfate in waters included in this study. Furthermore, the $\delta^{34} \mathrm{~S}_{\mathrm{SO} 4}$ combined with $\delta^{13} \mathrm{C}_{\mathrm{DIC}}$ has the potential to investigate the presence and extent of biogeochemical reactions occurring in specific environments. 


\section{CHAPTER 5}

\subsection{Conclusions}

Stable isotopes of water $\left(\delta^{18} \mathrm{O}_{\mathrm{H} 2 \mathrm{O}}\right.$ and $\left.\delta^{2} \mathrm{H}_{\mathrm{H} 2 \mathrm{O}}\right)$, DIC $\left(\delta^{13} \mathrm{C}_{\mathrm{DIC}}\right)$ and $\mathrm{SO}_{4}{ }^{2-}\left(\delta^{34} \mathrm{~S}_{\mathrm{SO} 4}\right.$ and $\left.\delta^{18} \mathrm{O}_{\mathrm{SO}}\right)$ were used in this study to delineate sources of water and carbon in three different geochemical settings in the Central Appalachian region, including natural springs, coal mine discharges and brines produced during shale gas drilling. The data collected indicate that isotopic compositions differ in natural springs, coal mine discharge and flowback waters due to variations in recharge sources, water-rock interactions and biogeochemical reactions. These variations impart a unique isotope signature to water, DIC and dissolved sulfate at these sampling sites.

In the case of natural springs and coal mine discharge settings, waters discharging on the surface were interpreted to be receiving contributions from meteoric waters, as their $\mathrm{O}$ and $\mathrm{H}$ isotopic compositions were similar to that of local precipitation. In addition, minor regional differences were also noted. The small regional differences in $\mathrm{O}$ and $\mathrm{H}$ isotope signatures could be attributed to differences in latitude of the sampling locations. The sampling sites at slightly higher latitudes (i.e. PA springs and coal mine discharge) had lower values compared to sites at lower latitude (i.e. WV/VA springs) which is expected based on Rayleigh fractionation model of precipitation. However, it is important to note that differences in altitude and time of recharge could be other/additional factors affecting the $\mathrm{H}$ and $\mathrm{O}$ isotopes of the sampled waters. Flowback waters in this study have significantly different isotope compositions for waters, deviating from local meteoric water. These differences can be attributed to the presence 
of formation brines which originated as old connate sea water which has undergone water-rock interactions within the geologic formation. Mixing of surface waters with produced brines does not seem to be apparent with the limited data for this study.

Carbon isotopes of DIC showed a wide range of values and were found to deviate from expected values of natural groundwaters at several sampling locations. Enriched values up $-2.4 \%$ in natural springs and coal mine discharges indicate greater contributions from old carbon released during dissolution of carbonates and transported as DIC. Sulfuric acid-enhanced weathering could be attributing to enhanced carbonate dissolution in the coal mine drainage site, mainly as a result of pyrite oxidation in the coals and overburden shale. A two end-member stable isotope mixing model supported enhanced carbonate dissolution since a majority $(>65 \%)$ of the DIC was determined to be from dissolution of carbonate rocks. Natural springs in this study were also found to receive significant contributions from carbonate carbon since the carbon isotope signatures were enriched beyond natural waters. The direct correlation of higher calcium and bicarbonate concentrations with higher $\delta^{13} \mathrm{C}$ values support enhanced carbonate dissolution in springs in West Virginia and Virginia. Additional isotope fractionation of carbon at all spring sites could be a result of $\mathrm{CO}_{2}$ outgassing since discharging waters have $\mathrm{CO}_{2}$ concentrations higher than atmospheric $\mathrm{CO}_{2}$ concentrations. The springs in PA also have tufa formations associated with them which further supports $\mathrm{CO}_{2}$ degassing. Carbon isotopes of DIC in flowback waters were found to be much more enriched in the heavy isotope $\left({ }^{13} \mathrm{C}\right)$ than natural groundwaters and all other waters sampled in this study. The very positive values of the flowback waters, as high as $+25.3 \%$, are most likely a result of bacterially-mediated methanogenesis where bacteria will preferentially 
incorporate the lighter isotope $\left({ }^{12} \mathrm{C}\right)$ in the formation of methane, leaving the residual much more enriched in the heavy isotope $\left({ }^{13} \mathrm{C}\right.$ ). The presence of Methanosarcinales sp. (a species of methanogenic bacteria) supports the possibility of biogenic methanogenesis in these flowback waters. The high carbon isotope signature of the flowback waters can therefore be used to fingerprint the flowback water in freshwater water aquifers and/or surface waters of the region.

Sulfur and oxygen isotopes of dissolved sulfate in natural springs and discharging mine waters were used to examine sources of sulfate and biogeochemical processes that affect the carbon isotopes of DIC. In Pennsylvania, the sampled springs fall very close to or within the range ( 0.2 to $3.4 \%$ ) of the $\delta^{34} \mathrm{~S}$ values of pyrite in coal and shale in the region $(+0.6$ to $+2.4 \%)$, indicating that the dissolved sulfate most likely originated from the oxidation of pyrite in this area. The coal mine discharge waters have $\delta^{34} \mathrm{~S}_{\mathrm{SO}}$ values within the range of dissolved sulfate originating as pyrite, but are slightly more enriched in ${ }^{34} \mathrm{~S}$ compared to the pyrite in coals/shales of the region. Natural springs in West Virginia and Virginia show a much more enriched isotope composition of S and O compared to the sampling sites in Pennsylvania, with S values up to $+40.4 \%$. Based on the $\mathrm{S}$ and $\mathrm{O}$ isotope composition it appears that dissolved sulfate in the springs of $\mathrm{WV}$ and VA originated from dissolution of marine evaporites of Silurian-Devonian and Ordovician age (+ 25 to $+30 \%$ o). At some of the spring sites in WV and VA, and at the coal mine discharge site, the $\mathrm{S}$ and $\mathrm{O}$ isotope values were higher than that of the source rock. This could be attributed to bacterially-mediated sulfate reduction where sulfatereducing bacteria preferentially remove the lighter isotopes $\left({ }^{32} \mathrm{~S}\right.$ and $\left.{ }^{16} \mathrm{O}\right)$ leaving behind a sulfate pool enriched in the heavy isotopes $\left({ }^{34} \mathrm{~S}\right.$ and $\left.{ }^{18} \mathrm{O}\right)$. 
The geochemical settings investigated in this study offered an opportunity to use stable isotopes to understand processes related to water cycling and water-rock interactions which may ultimately impact the quality of the water. The interpretations and conclusions for these systems were based on the limited data collected for this study. These systems are extremely diverse and complex, therefore not all possible reactions and/or transformations are considered and the magnitudes of different processes are not known. Future research is needed to explore possible variations as well as spatial and temporal trends at these sites, but this research provides a foundation for delineating sources of water and investigating the possible biogeochemical transformations taking place in different geochemical settings of the Central Appalachian region. 


\section{APPENDIX}

Table 1-Specific site information for each sampled location in this study. Table includes site name, ID, sampling date, location, relevant geology and additional information regarding where samples were taken.

\begin{tabular}{|c|c|c|c|c|c|}
\hline Site Name & Site ID & Sample Date & Site Location & Pertinent Geology & Additional Information \\
\hline Port Royal & PRT & $6 / 15 / 2011$ & Westmoreland County, PA & Bentwood Ls., Monongahela Group & Sample taken at source; depositing tufa \\
\hline Cedar Creek & $\begin{array}{l}\mathrm{CC} 02, \mathrm{CC} 03 \\
\quad \mathrm{CCSS}\end{array}$ & $6 / 15 / 2011$ & Westmoreland County, PA & Bentwood Ls., Monongahela Group & $\begin{array}{l}3 \text { seeps were sampled }(\mathrm{CC} 02, \mathrm{CC} 03) \text { right next to eachother and CCSS } \\
\text { is a small flow/drip at streamside; depositing tufa }\end{array}$ \\
\hline Smithton & SM01, SM02 & 6/15/2011 & Westmoreland County, PA & Bentwood Ls., Monongahela Group & $\begin{array}{l}2 \text { seeps collected (SM01, SM02) right next to eachother at base of } \\
\text { waterfall; SM02 was sheet flow; depositing tufa }\end{array}$ \\
\hline Mayview & MV & 6/15/2011 & Allegheny County, PA & Bentwood Ls., Monongahela Group & Sample taken at source; depositing tufa \\
\hline Old Sweet Spring & OLDSWT & $6 / 28 / 2012$ & Monroe County, WV & Middle Ordovician Undivided & Old mineral spring spa; samples taken from main pool \\
\hline Octagon Spring & OCTAG & $6 / 29 / 2012$ & Bath County, VA & \multirow{5}{*}{$\begin{array}{l}\text { Juniata, Oswego, Martinsburg, and } \\
\text { Eggleston Formations, Ordovician }\end{array}$} & Main spring at Homestead resort \\
\hline Magnesia Spring & $\begin{array}{l}\text { MAGNESA, } \\
\text { MAGCOLD }\end{array}$ & 6/29/2011 & Bath County, VA & & $\begin{array}{l}\text { Spring located under pavalion at Homestead resort; MAGCOLD taken } \\
\text { from cold spring outside resort }\end{array}$ \\
\hline Boiler Spring & BOILER & 6/29/2011 & Bath County, VA & & Spring located under pavalion at Homestead resort \\
\hline Hot Sulfur Spring & HOTSULF & $6 / 29 / 2011$ & Bath County, VA & & Spring located under pavalion at Homestead resort \\
\hline Jefferson Spring & JEFFD & $6 / 29 / 2011$ & Bath County, VA & & Spring located under pavalion \\
\hline Big Spring & VABIG & 6/29/2011 & Bath County, VA & $\begin{array}{l}\text { Juniata, Oswego, Martinsburg, and } \\
\text { Eggleston Formations, Ordovician }\end{array}$ & Spring located at head of small stream along roadway \\
\hline $\begin{array}{l}\text { Sweet Chalybeate } \\
\text { Spring }\end{array}$ & $\begin{array}{l}\text { CHAL, } \\
\text { CHAL2C, } \\
\text { CHAL2M }\end{array}$ & 6/28/2011 & Alleghany County, VA & $\begin{array}{l}\text { Beekmantown Group/Lower } \\
\text { Ordovician }\end{array}$ & $\begin{array}{l}3 \text { springs collected (CHAL, CHAL2C, CHAL2M); CHAL old mineral } \\
\text { spring, CHAL2C cold spring emerging at back of CHAL2, CHAL2M } \\
\text { mixed of thermal mineral (CHAL2) and CHAL2C }\end{array}$ \\
\hline Spellman Spring & SPELM & $6 / 28 / 2011$ & Alleghany County, VA & Middle Ordovician Undivided & Karst spring \\
\hline Iron Falls & Fe-FALLS & $\begin{array}{l}12 / 3 / 2010 \\
2 / 12 / 2011 \\
7 / 27 / 2011\end{array}$ & Allegheny County, PA & $\begin{array}{c}\text { Pittsburgh Formation, Monongahela } \\
\text { Group }\end{array}$ & Coal mine discharge; samples taken directly from portal (3X) \\
\hline Mohr \#6 & MOHR6 & $3 / 10 / 2012$ & Greene County, PA & \multirow{3}{*}{$\begin{array}{l}\text { Marcellus Formation, Middle- } \\
\text { Devonian }\end{array}$} & Shale gas drilling site; samples taken from spigiot on holding tank \\
\hline Blaker - 8 & BLAKER8 & 3/10/2012 & Greene County, PA & & Shale gas drilling site; samples taken from spigiot on holding tank \\
\hline Meadows - 4 & MEADOWS4 & 3/10/2012 & Greene County, PA & & Shale gas drilling site; samples taken from spigiot on holding tank \\
\hline
\end{tabular}


Table 2-Field parameters collected with a YSI-556MP meter (Moore, 2012; Adams, 2012) Temperature and $\mathrm{pH}$ were the main parameters used in this study.

\begin{tabular}{|c|c|c|c|c|c|}
\hline Site ID & $\begin{array}{c}\text { Temperature } \\
\left({ }^{\circ} \mathrm{C}\right)\end{array}$ & $\mathrm{pH}$ & $\begin{array}{c}\text { Specific } \\
\text { Conductivity } \\
(\mathrm{mS} / \mathrm{cm})\end{array}$ & $\begin{array}{l}\text { Oxidation Reduction } \\
\text { Potential }(\mathrm{mV})\end{array}$ & DO (\%) \\
\hline PRT & 12.1 & 7.19 & 615 & $*$ & $*$ \\
\hline $\mathrm{CCO} 2$ & 15.2 & 8.19 & 351 & $*$ & $*$ \\
\hline $\mathrm{CC} 03$ & 13.5 & 7.76 & 1355 & $*$ & $*$ \\
\hline CCSS & 13.9 & 7.94 & 972 & $*$ & $*$ \\
\hline SM01 & 15.2 & 8.44 & 795 & $*$ & $*$ \\
\hline SM02 & 16.4 & 8.54 & 729 & $*$ & $*$ \\
\hline MV & 11.3 & 7.89 & 551 & $*$ & $*$ \\
\hline OLDSWT & 22.7 & 7.27 & 1704 & 132.1 & 17.1 \\
\hline OCTAG & 36.7 & 7.00 & 929 & 60.0 & 25.2 \\
\hline MAGNESA & 31.0 & 6.83 & 917 & 9.0 & 13.9 \\
\hline MAGCOLD & 12.3 & 6.79 & 774 & -13.9 & 75.9 \\
\hline BOILER & 40.1 & 6.32 & 941 & 33.6 & 5.1 \\
\hline HOTSULF & 35.9 & 6.91 & 925 & 19.2 & 6.9 \\
\hline JEFFD & 35.4 & 6.79 & 774 & -232 & 10.3 \\
\hline VABIG & 13.2 & 7.39 & 194 & -36.5 & 72.6 \\
\hline CHAL & 23.2 & 6.39 & 1788 & -36.5 & 8.7 \\
\hline CHAL2C & 19.0 & 6.22 & 1430 & -35.0 & 13.6 \\
\hline CHAL2M & 21.1 & 6.28 & 1656 & -51.8 & 7.0 \\
\hline SPELM & 12.5 & 7.21 & 429 & 110 & 56.2 \\
\hline Fe-FALLS (a) & 11.94 & 6.23 & 1.25 & 77.6 & 30 \\
\hline Fe-FALLS (b) & 11.49 & 6.28 & 1.36 & -0.7 & 37.1 \\
\hline Fe-FALLS (c) & 13.6 & 5.97 & 1.85 & -14.5 & 37.1 \\
\hline
\end{tabular}


Table 3-Reported stable isotope values for all sampling sites. Note the (*) represents no data.

\begin{tabular}{|c|c|c|c|c|c|}
\hline Site ID & $\delta^{13} \mathrm{C}_{\mathrm{DIC}}$ & $\delta^{2} \mathrm{H}_{\mathrm{H} 2 \mathrm{O}}$ & $\delta^{18} \mathrm{O}_{\mathrm{H} 2 \mathrm{O}}$ & $\delta^{34} \mathrm{~S}_{\mathrm{SO} 4}$ & $\delta^{18} \mathrm{O}_{\mathrm{SO} 4}$ \\
\hline PRT & -12.4 & -56.2 & -8.4 & 0.2 & 1.1 \\
\hline $\mathrm{CC} 02$ & -8.5 & -56.7 & -8.6 & 3.1 & 3.7 \\
\hline $\mathrm{CCO3}$ & -16.2 & -56.7 & -8.5 & $*$ & $*$ \\
\hline CCSS & -8.0 & -55.1 & -8.4 & $*$ & $*$ \\
\hline SM01 & -10.1 & -57.4 & -8.5 & 0.3 & 3.5 \\
\hline SM02 & -10.7 & $*$ & $*$ & $*$ & $*$ \\
\hline MV & -11.5 & -56.7 & -8.7 & 3.4 & 2.7 \\
\hline OLDSWT & -2.4 & -53.2 & -8.3 & 40.2 & 15.3 \\
\hline OCTAG & -3.0 & -54.3 & -8.7 & 37.9 & 14.1 \\
\hline MAGNESA & -3.1 & -51.9 & -7.9 & 36.3 & 14.3 \\
\hline MAGCOLD & -13.8 & -50.0 & -8.2 & 19.9 & 8.9 \\
\hline BOILER & -3.2 & -54.4 & -8.7 & 37.6 & 14.8 \\
\hline HOTSULF & -3.3 & -53.8 & -8.7 & 37.8 & 14.2 \\
\hline JEFFD & -5.8 & -51.3 & -8.3 & 39.3 & 15.0 \\
\hline VABIG & -11.7 & -53.2 & -8.4 & $*$ & $*$ \\
\hline CHAL & -2.4 & -54.2 & -8.5 & 40.4 & 15.1 \\
\hline CHAL2C & -3.8 & -53.8 & -8.5 & 40.2 & 14.5 \\
\hline CHAL2M & -3.2 & -53.9 & -8.6 & 40.4 & 14.7 \\
\hline SPELM & -10.2 & -54.2 & -8.5 & 30.2 & 11.8 \\
\hline Fe-FALLS (a) & -6.4 & -55.6 & -8.3 & 8.2 & 4.0 \\
\hline Fe-FALLS (b) & -9.0 & -54.6 & -8.2 & 8.6 & 4.4 \\
\hline Fe-FALLS (c) & -10.2 & -56.6 & -8.5 & 9.7 & 5.1 \\
\hline MOHR6 & 21.9 & -31.5 & -2.5 & $*$ & $*$ \\
\hline BLAKER8 & 25.3 & -36.5 & -2.4 & $*$ & $*$ \\
\hline MEADOWS4 & 24.8 & -38.8 & -2.4 & $*$ & $*$ \\
\hline
\end{tabular}


Table 4-Specific cations and anions pertinent to this study. Samples were analyzed at the DOE/NETL in Pittsburgh, PA (Moore, 2012, Adams, 2012).

\begin{tabular}{|c|c|c|c|c|c|c|}
\hline Site ID & $\mathrm{Ca}^{2+} \mathrm{mg} / \mathrm{L}$ & $\mathrm{Na}^{+} \mathrm{mg} / \mathrm{L}$ & $\mathrm{Mg}^{2+} \mathrm{mg} / \mathrm{L}$ & $\mathrm{K}^{+} \mathrm{mg} / \mathrm{L}$ & $\mathrm{SO}_{4}{ }^{2-} \mathrm{mg} / \mathrm{L}$ & $\mathrm{Cl}^{-} \mathrm{mg} / \mathrm{L}$ \\
\hline PRT & 93.6 & $*$ & $*$ & 25.63 & 95.0 & $*$ \\
\hline $\mathrm{CC} 02$ & 62.7 & $*$ & $*$ & 17.65 & 58.4 & $*$ \\
\hline $\mathrm{CC} 03$ & 87.2 & $*$ & $*$ & 27.21 & 85.0 & $*$ \\
\hline CCSS & 63.4 & $*$ & $*$ & 23.37 & 103.0 & $*$ \\
\hline SM01 & 32.0 & $*$ & $*$ & 8.31 & 59.0 & $*$ \\
\hline SM02 & 35.7 & $*$ & $*$ & 6.62 & 35.0 & $*$ \\
\hline MV & 60.1 & $*$ & $*$ & 29.02 & 117.0 & $*$ \\
\hline OLDSWT & 295.1 & 19.8 & 60.7 & 25.7 & 395.1 & 28.7 \\
\hline OCTAG & 124.5 & 0.01 & 3.4 & 13.1 & 127.6 & 2.7 \\
\hline MAGNESA & 119.6 & 6.6 & 33.0 & 12.6 & 129.2 & 2.7 \\
\hline MAGCOLD & 48.0 & 2.2 & 3.3 & 1.0 & 13.5 & 3.4 \\
\hline BOILER & 119.0 & 6.2 & 0.03 & 12.53 & 126.8 & 2.6 \\
\hline HOTSULF & 118.5 & 0.01 & 32.4 & 12.6 & 131.1 & 2.6 \\
\hline JEFFD & 97.4 & 3.6 & 0.02 & 6.85 & 225.5 & 1.5 \\
\hline VABIG & 29.1 & 1.3 & 4.2 & 0.2 & 5.9 & 0.5 \\
\hline CHAL & 284.0 & 19.7 & 55.8 & 26.5 & 426.6 & 30.9 \\
\hline CHAL2C & 250.5 & 13.2 & 49.8 & 18.1 & 417.9 & 20.1 \\
\hline CHAL2M & 271.1 & 14.2 & 54.5 & 20.1 & 434.9 & 20.6 \\
\hline SPELM & 58.2 & 1.8 & 0.02 & 1.99 & 20.3 & 3.0 \\
\hline Fe-FALLS (a) & 94.7 & 85.5 & 35.6 & 2.73 & 322.4 & $*$ \\
\hline Fe-FALLS (b) & 96.3 & 114.9 & 37.5 & 2.46 & 328.4 & $*$ \\
\hline Fe-FALLS (c) & 108.7 & 182.9 & 44.1 & 3.6 & 628.0 & $*$ \\
\hline MOHR6 & 10970 & 34020 & 0.9 & 167.0 & 63.0 & 82860 \\
\hline BLAKER8 & 13010 & 37820 & 946 & 228 & 61.3 & 86010 \\
\hline MEADOWS4 & 14900 & 43620 & 1059 & 236 & 61.0 & 92930 \\
\hline
\end{tabular}


Table 5-Reported alkalinity and calculated dissolved inorganic carbon concentrations. Note DIC concentrations are in mg of carbon per liter.

\begin{tabular}{|c|c|c|}
\hline Site ID & Alkalinity as $\mathrm{HCO}_{3}^{-} \mathrm{mg} / \mathrm{L}$ & $\mathrm{DIC} \mathrm{mg} \mathrm{C} / \mathrm{L}$ \\
\hline PRT & 401 & 92.5 \\
\hline $\mathrm{CCO} 2$ & 269 & 54.0 \\
\hline $\mathrm{CCO3}$ & 555 & 114.4 \\
\hline CCSS & 353 & 71.8 \\
\hline SM01 & 379 & 76.0 \\
\hline SM02 & 331 & 66.4 \\
\hline MV & 430 & 87.8 \\
\hline OLDSWT & 784 & 173.6 \\
\hline OCTAG & 172 & 40.4 \\
\hline MAGNESA & 434 & 111.6 \\
\hline MAGCOLD & 154 & 43.3 \\
\hline BOILER & 436 & 162.4 \\
\hline HOTSULF & 400 & 97.6 \\
\hline JEFFD & 201 & 52.1 \\
\hline VABIG & 111 & 24.2 \\
\hline CHAL & 731 & 278.2 \\
\hline CHAL2C & 627 & 303.4 \\
\hline CHAL2M & 637 & 280.4 \\
\hline SPELM & 270 & 61.9 \\
\hline Fe-FALLS (a) & 152 & 77.0 \\
\hline Fe-FALLS (b) & 168 & 79.8 \\
\hline Fe-FALLS (c) & 146 & 98.2 \\
\hline MOHR6 & 32.9 & $*$ \\
\hline BLAKER8 & 19.5 & $*$ \\
\hline MEADOWS4 & 20.7 & $*$ \\
\hline
\end{tabular}


Table 6-Measued carbon, sulfur and oxygen isotope values for end-members. Note the * represents bulk analysis.

\begin{tabular}{|c|c|c|}
\hline Sample & $\delta^{13} \mathrm{C} \%{ }^{*} *$ & $\delta^{34} \mathrm{~S} \%$ * \\
\hline Pittsburgh Coal & -24.3 & 0.6 \\
\hline Little Pittsburgh Coal & -25.4 & 2.4 \\
\hline Pittsburgh Shale & -21.6 & 1.8 \\
\hline Sample & $\delta^{13} \mathrm{C}_{\mathrm{CO} 3} \%$ & $\delta^{18} \mathrm{O}_{\mathrm{CO} 3} \%$ \\
\hline Upper Dev/Si Limestone (New Creek?) & -5.0 & -9.7 \\
\hline Upper Dev/Si Limestone (Tonoloway) & -5.6 & -8.4 \\
\hline Upper Dev/Si Limestone (Tonoloway) & -5.0 & -7.9 \\
\hline PA Coal Carbonates & -2.7 & -15.33 \\
\hline Pittsburgh Fm. Limestone & -2.5 & -0.42 \\
\hline Pittsburgh Fm. Limestone & -1.7 & -1.73 \\
\hline
\end{tabular}




\section{REFERENCES}

Adams, J.P. 2012. The geochemistry and $\mathrm{CO}_{2}$ flux of two mine discharges, Allegheny County Pennsylvania. MS Thesis, West Virginia University.

Ali, H.N., and E.A. Atekwana. 2009. Effect of progressive acidification on stable carbon isotopes of dissolved inorganic carbon in surface waters. Chemical Geology 260, no. 1-2: $102-111$.

Amano, Y. 2011. Why Water Matters. IAEA Bulletin 53-1.

< http://www.iaea.org/Publications/Magazines/Bulletin/Bull531/53105910202.pdf>

Andrews, A., C. Copeland, P. Folger, M. Humphries, R. Meltz, and M. Tieman. 2009. Natural Gas Drilling in the Marcellus Shale. Congressional Research Service Memorandum. <www.crs.gov>

Andrews, J. E. 2006. Paleoclimatic records from stable isotopes in riverine tufas: Synthesis and review. Earth-Science Reviews 75, no. 1-4: 85-104.

Aravena, R., S.L. Schiff, S.E. Trumbore, P.J. Dillon, and R. Elgood. 1992. Evaluating Dissolved Inorganic Carbon Cycling in a Forested Lake Watershed Using Carbon Isotopes. Radiocarbon 34, no. 3: 636-645.

Arthur, J.D., M. Uretsky, and P. Wilson. 2010. Water Resources and Use for Hydraulic Fracturing in the Marcellus Shale Region. Water Resource Issues in the Marcellus Shale Region. ALL Consulting, Tulsa, OK. < http://www.netl.doe.gov/technologies/oilgas/publications/ENVreports/FE0000797_WaterResourceIssues.pdf>

Atekwana, E.A., and E.W. Fonyuy. 2009. Dissolved inorganic carbon concentrations and stable carbon isotopes ratios in streams polluted by variable amounts of acid mine drainage. Journal of Hydrology 372, no. 1-4: 136-148.

Atekwana, E.A., and D.S. Richardson. 2004. Geochemical and Isotopic Evidence of a Groundwater Source in the Corral Canyon Meadow Complex, Central Nevada, USA, Hydrological Processes 18, no. 18: 2801-2815.

Atekwana, E.A. 1996. Hydrogeology and Stable Isotope Investigations of a Landfill Impacted Site In Southwest Michigan, Western Michigan University. Ph.D Dissertation: 197pp. 
Barbieri, M., T. Boschetti, M. Petitta, and M. Tallini. 2005. Stable isotope $\left({ }^{2} \mathrm{H},{ }^{18} \mathrm{O}\right.$ and ${ }^{87} \mathrm{Sr} /{ }^{86} \mathrm{Sr}$ ) and hydrochemistry monitoring for groundwater hydrodynamics analysis in a karst aquifer (Gran Sasso, Central Italy). Applied Geochemistry 20, no. 11: 2063-2081.

Berner, Z.A., D. Stüben, M.A. Leosson, and H. Klinge. 2002. S- and O-Isotopic Character of Dissolved Sulphate in the Cover Rock Aquifers of a Zechstein Salt Dome. Applied Geochemistry 17, no. 12: 1515-1528.

Blasch, K.W., and J. R. Bryson. 2007. Distinguishing Sources of Ground Water Recharge by Using $\delta^{2} \mathrm{H}$ and $\delta^{18} \mathrm{O}$. Ground Water 45, no. 3: 294-308.

Blauch, M.E., R.R. Myers, T.R. Moore, B.A. Lipinski, and N.A. Houston. 2009. Marcellus Shale Post-Frac Flowback Waters-Where is All the Salt Coming from and What are the Implications? SPE International, SPE 125740, 1-20.

Börjesson, G., J. Samuelsson, and J. Chanton. 1997. Methane Oxidation in Swedish Landfills Quantified with the Stable Carbon Isotope Technique in Combination with an Optical Method for Emitted Methane. Environmental Science Technology 41, no. 19: 6684-6690.

Bowen, G.J. 2012. The Online Isotopes in Precipitation Calculator, version 2.2. $<$ http://www.waterisotopes.org >

Brady, K., B.C. Michael, W. Smith, and J. Schueck. 1998. Coal Mine Drainage Prediction and Pollution Prevention in Pennsylvania. Pennsylvania Department of Environmental Protection. Harrisburgh, PA; 92pp.

Brunet, F., D. Gaiero, J.L. Probst, P.J. Depetris, F. Gaithier Lafaye, and P. Stille. 2005. $\delta^{13} \mathrm{C}$ tracing of dissolved inorganic carbon sources in Patagonian rivers (Argentina). Hydrological Processes 19, no: 17: 3321-3344.

Brunner, B., S.M. Bernasconi, J. Kleikemper, and M.H. Schroth. 2005. A model for oxygen and sulfur isotope fractionation in sulfate during bacterial sulfate reduction processes. Geochimica et Cosmochimica Acta 69, no. 20: 4773-4785.

Burns, S.J. 1998. Carbon Isotopic Evidence for Coupled Sulfate Reduction-Methane Oxidation in Amazon Fan Sediments. Geochimica et Cosmochimica Acta 62, no. 5: 797-804. 
Capo, R.C., W.R. Winters, T.J. Weaver, S.L. Stafforf, R.S Hedin, and B.W. Stewart. 2001. Hydrogeologic and geochemical evolution of deep mine discharges, Irwin Syncline, Pennsylvania: Proceeding. West Virginia Surface Mine Drainage Task Force Symposium 22, 144-153.

Cartwright, I., K. Hannam, and T.R. Weaver. 2007. Constraining flow paths of saline groundwater at basin margins using hydrochemistry and environmental isotopes:Lake Cooper, Murray Basin, Australia. Australian Journal of Earth Sciences 54, no. 8: 1103-1122.

Chapman, E.C., R.C. Capo, B.W. Stewart, R. Hammack, K. Schroeder, and H.M. Edenborn. 2012. Geochemical and strontium isotope characterization of produced waters from Marcellus Shale natural gas extraction. Environmental Science Technology 46, no. 6: 3545-3553.

Chae, G.T., S.T. Yun, K. Kim, and B. Mayer. 2006. Hydrogeochemistry of sodiumbicarbonate type bedrock groundwater in the Pocheon spa area, South Korea: water-rock interaction and hydrologic mixing. Journal of Hydrology 321, no. 1-4: 326-343.

Cheung, K., P. Klassen, B. Mayer, F. Goodarzi, and R. Aravena. 2010. Major Ion and Isotope Geochemistry of Fluids and Gases From Coal Bed Methane and Shallow Groundwater Wells in Alberta, Canada. Applied Geochemistry 25, no. 9: 13071329.

Church, C.D., R.T. Wilkin, C.N. Alpers, R.O. Rye, and R.B. McCleskey. 2007. Microbial sulfate reduction and metal attenuation in $\mathrm{pH} 4$ acid mine water. Geochemical Transactions 8, no. 10: 1-14.

Clark, I., and P. Fritz. 1997, Environmental isotopes in hydrogeology. Boca Raton, Florida, Lewis Publishers: 328pp.

Claypool, G.E., W.T. Holser, I.R. Kaplan, H. Sakai, and I. Zak. 1980. The age curve of sulfur and oxygen isotopes in marine sulfate and their mutual interpretation. Chemical Geology 28: 199-260.

Clayton, R.N., I., Friedman, D.L., Graf, T.K., Mayeda, W.F., Meents, and N.F. Shimp. 1966. The Origin of Saline Formation Waters 1. Isotopic Composition, Journal of Geophysics Research 71, no. 16: 3869-3882. 
Coplen, T.B., and B.B. Hanshaw. 1973. Ultrafiltration by a compacted clay membrane I. Oxygen and hydrogen isotopic fractionation. Geochimica et Cosmochimica Acta 37, no. 10: 2295-2310.

Craig, H. 1961. Isotopic Variations in Meteoric Waters, Science 133: 1702-1703.

Dansgaard, W. 1964. Stable Isotopes in Precipitation, Tellus 16, no. 4: 436-468.

Davis, S.N., G.M. Thompson, H.W. Bentley, and G. Stiles. 1980. Ground-Water Tracers-A Short Review. Ground Water 18, no. 1: 14-23.

Doctor, D.H., C. Kendall, S.D. Sebestyen, J.B. Shanley, N. Ohte, and E.W. Boyer. 2008. Carbon isotope fractionation of dissolved inorganic carbon (DIC) due to outgassing of carbon dioxide from a headwater stream. Hydrological Processes 22, no. 14: 2410-2423.

Drever, J.I. 1997. The Geochemistry of Natural Waters: Surface and Groundwater Environments. Upper Saddle River, New Jersey, Prentice Hall, Inc., 3: 436pp.

Du, J., W. Cheng, Y. Zhang, C. Jie, Z. Guan, W. Liu, and L. Bai. 2006. Helium and carbon isotopic compositions of thermal springs in the earthquake zone of Sichuan, Southwestern China. Journal of Asian Earth Sciences 26, no. 5: 533539.

Epstein, S., and R. P. Sharp. 1965. Six-Year Record of Oxygen and Hydrogen Isotope Variations in South Pole Firn. Journal of Geophysical Research 70, no. 8: 1809 1814

Evans, M.A., and D.A. Battles. 1999. Fluid inclusion and stable isotope analysis of veins from the central Appalachian Valley and Ridge province: implications for regions synorogenic hydrologic structure and fluid migration. Geological Society of America Bulletin 111: 1841-1860.

Favara, R., F. Grassa, S. Inguaggiato, and M. Valenza. 2001. Hydrogeochemistry and stable isotopes of thermal springs: earthquake-related chemical changes along Belice Fault (Western Sicily). Applied Geochemistry 16, no. 1: 1-17.

Finlay, J.C. 2003. Controls of streamwater dissolved inorganic carbon dynamics in a forested watershed. Biochemistry 62: 231-252. 
Fonyuy, E.W., and E.A. Atekwana. 2008. Effects of acid mine drainage on dissolved inorganic carbon and stable isotopes in receiving streams. Applied Geochemistry 23, no. 4: 743-764.

Fouillac, C., A.M. Fouillic, and A. Criaud. 1990. Sulphur and oxygen isotopes of dissolved sulphur species formation waters from the Dogger geothermal aquifer, Paris Basin, France. Applied Geochemistry 5, no. 4: 415-427.

Fricke, H.C., and J.R. O'Neil. 1999. The correlation between ${ }^{18} \mathrm{O} /{ }^{16} \mathrm{O}$ ratios of meteoric water and surface temperature: its use in investigating terrestrial climate change over geologic time. Earth and Planetary Science Letters 170, no. 3: 181-196.

Gammons, C.H., T.E. Duaime, S.R. Parker, S.R. Poulson, and P. Kennelly. 2009. Geochemistry and Stable Isotope Investigation of Acid Mine Drainage Associated With Abandoned Coal Mines in Central Montana, USA. Chemical Geology 269, no. 1-2: 100-112.

Garchar, L., and G. Arehart. 2008. Origin and Characterization of Geothermal Waters at Desert Queen, Nevada. Geothermal Resources Council Transactions 32: 147-151.

Gat, J.R., C.J. Bowser, and C. Kendall. 1994. The Contribution of Evaporation from the Great Lakes to the Continental Atmosphere: Estimate Based on Stable Isotope Data. Geophysical Research Letters 21, no. 7: 557-560.

Gat, J. R., A. Shemesh, E. Tziperman, A. Hect, D. Georgopoulos, and O. Basturk. 1996. The stable isotope composition of the eastern Mediterranean Sea. Journal of Geophysical Research 101, no. C3: 6441-6451.

Gat, J. R., W.G. Mook, and A.J. Meijer. 2001. Environmental Isotopes in the Hydrological Cycle: Principles and Application 39, II: 1-122.

Geyh, M. 2001. Environmental Isotopes in the Hydrological Cycle: Principles and Application 39, IV: 1-200.

Ghomshei, M.M., and D.M. Allen. 1999. Potential application of oxygen-18 and deuterium in mining effluent and acid rock drainage studies. Environmental Geology 39, no. 7: 767-773.

Gould, W.D., and A. Kapoor. 2003. The Microbiology of Acid Mine Drainage. In Environmental Aspects of Mine Waters, eds. J.L. Jambor, D.W. Blowes and A. I.M Ritchie, Springer Berlin, vol. 31. Vancouver, British Colombia. 
Graf, G.L., I. Friedman, and W.F. Meents. 1965. The origin of saline formation waters, II: Isotopic fractionation by shale micropore systems. Illinois State Geological Survey Circular 393: 32.

Hayes, T. 2009. Sampling and Analysis of Water Streams Associated with the Development of Marcellus Shale Gas, Gas Technology Institute. http://catskillcitizens.org/learnmore/20100916IOGAResponsetoDECChesapeake

Hazen, J.M., M.W. Williams, B. Stover, and M. Wireman. 2002. Characterization of Acid Mine Drainage Using a Combination of Hydrometric, Chemical and Isotopic Analyses, Mary Murphy Mine, Colorado. Environmental Geochemistry and Health 24, no. 1: 1-22.

Hellings, L., F. Dehairs, S. Van Damme, and W. Baeyens. 2001. Dissolved inorganic carbon in a highly polluted estuary (the Scheldt). Limnology and Oceanography 46: 1406-1414.

Hendy, C.H. 1971. The isotopic geochemistry of speleothems-I. The calculation of the effects of different modes of formation on the isotopic composition of speleothems antheir applicability as palaeclimatic indicators. Geochimica et Cosmochimica Acta 35, no. 8: 801-824.

Hobba, W.A., D.W. Fisher, F.J. Pearson, and J.C. Chemerys. 1979. Hydrology and Geochemistry of Thermal Springs of the Appalachians, USGS PP 1044E: 1-36.

Hoyle, A., and E. J. Dasch. 2012. Brines, Natural, Water Encyclopedia Science and Issues. 〈http://www.waterencyclopedia.com/Bi-Ca/Brines-Natural.html>

Horita, J. 2005. Saline Waters. In Isotopes in the Water Cycle: Past, Present and Future of a Developing Science. International Atomic Energy Agency,eds.P.K. Aggarwal, J.R. Gat, and K.F Froehlich, 279-287, Netherlands: Springer.

Hunt, R.J., T.B. Coplen, N.L. Haas, D.A. Saad, and M.A. Borchardt. 2005. Investigating Surface Water-Well Interaction Using Stable Isotope Ratios of Water. Journal of Hydrology 302, no. 1-4: 154-172.

Ihlenfeld, C., M.D. Norman, M.K. Gagan, R.N. Drysdale, R. Maas, and J. Webb. 2003. Climatic significance of seasonal trace element and stable isotope variation in a modern freshwater tufa, Geochimica et Cosmochimica Acta 67, no. 13: 23412357. 
Kendall, C., and E.A. Caldwell. 1998. Isotope Tracers in Catchment Hydrology, Chapter 2, 51-86, eds. C. Kendall and J.J McDonnell, Amsterdam: Elsevier Science B.V. Kendall, C., and T. B. Coplen. 2001. Distribution of Oxygen-18 and Deuterium in River Waters Across the United States. Hydrological Processes 15 no. 7: 1363-1393. Kesler, S.E., T.W. Vennemann, C. Frederickson, A. Breithaupt, R. Vazquez, and F. C. Furman. 1997. Hydrogen and oxygen isotope evidence for origin of MVTforming brines, southern Appalachians. Geochimica et Cosmochimica Acta 61, no. 7: 1513-1523.

Kharaka, Y.K., and F.A.F. Berry. 1973. Isotopic composition of oil-field brines from Kettleman North Dome, California, and their geologic implications. Geochimica et Cosmochimica Acta, 37, no. 8: 1899-1908.

Kharaka, Y.K., and J.J. Thordsen. 1992. Stable Isotope Geochemistry and Origin of Waters in Sedimentary Basins. In Isotope Signatures and Sedimentary Records, eds. N. Clauer, and S. Chaudouri, 441-466, Springer Berlin / Heidelberg, Germany.

Kharaka, Y.K., and R.H. Mariner. 2005. Geothermal Systems. In Isotopes in the Water Cycle: Past, present and Future of a Developing Science. International Atomic Energy Agency, 243-270, Berline: Springer.

Kim, Y., K.S. Lee, D.C. Koh, D.H. Lee, S.G. Lee, W.B. Park, G.W. Koh, and N.C. Woo. 2003. Hydrogeochemical and isotopic evidence of groundwater salinization in coastal aquifer: a case study in Jeju volcanic island, Korea. Journal of Hydrology 270, no. 3-4: 282-294.

Koski, A.K., and S.A. Wood. 2004. The geochemistry of geothermal waters in the Alvord Basin, southeastern Oregon. Proceedings-International Symposium on Water Rock Interaction 11.

Krouse, H.R., W.D. Gould, R.G.L. McCready, and S. Rajan. 1991. ${ }^{18}$ O Incorporation into Sulphate During the Bacterial Oxidation of Sulphide Minerals and the Potential for Oxygen Isotope Exchange Between $\mathrm{O}_{2}$ and $\mathrm{H}_{2} \mathrm{O}$ and Oxidized Sulphur Intermediates. Earth and Planetary Science Letters 107, no. 1: 90-94.

Krouse, H.R., B. Mayer, and J.J. Schoneau. 1996. Applications of Stable Isotope Techniques to Soil Sulfur Cycling. Mass Spectrometry of Soils 1: 247-284. 
Krouse, H.R., and B. Mayer. 2000. Sulphur and Oxygen Isotopes in Sulphate. In Environmental Tracers in Subsurface Hydrology, 195-231, eds. P. Cook and A. L. Herczeg. Norwell, MA: Kluwer Academic Publishers.

Kumar, P., N.K. Das, C. Mallik, and R.K. Bhandari. 2011. Stable isotopes study on geothermal waters in eastern India. Current Science 101, no. 9: 1205-1209.

Kuykendall, T. 2010. West Virginia looks good for geothermal energy production, The Herald,Beckley, West Virginia. < http://www.registerherald.com/local/x921681819/W-Va-looks-good-for-geothermal-energyproduction>

Laughrey, C.D., and F.J. Baldassare. 1998. Geochemistry and Origin of Some Natural Gases in the Plateau Province, Central Appalachian Basin, Pennsylvania and Ohio. American Association of Petroleum Geologists Bulletin 82, no. 2: 317-355.

Lawrence, A.R., J.W. Lloyde, and J.M. Marsh. 1976. Hydrochemistry and Ground-Water Mixing in Part of the Lincolnshire Limestone Aquifer, England. Ground Water 14, no. 5: 320-327.

Ludwig, W., P. Amiotte-Suchet, and J. L. Probst. 1996. River discharges of carbon to the world's oceans: determining local inputs of alkalinity and of dissolved particulate organic carbon. Surface Geosciences 323: 1007-1014.

Maekawa, T., S.I. Igari, and N. Kaneko. 2006. Chemical and isotopic compositions of brines from dissolved in-water type natural gas fields in Chiba, Japan.

Geochemical Journal 40, no. 5: 475-484.

Marfia, A.M., R.V. Krishnamurthy, E.A. Atekwana, and W.F. Panton. 2004. Isotopic and Geochemical Evolution of Ground and Surface Waters in a Karst Dominated Geological Setting: A Case Study from Belize, Central America. Applied Geochemistry, 19, no. 6: 937-946.

Mayo, A.L., P.J. Nielson, M. Loucks, and W. H. Brimhall. 1992. The Use of Solute and Isotopic Chemistry to Identify Flow Patterns and Factors Which Limit Acid Mine Drainage in the Wasatch Range, Utah. Ground Water 30, no. 2: 243-249.

McColloch, C. M, W.P. Diamond, B.M. Bench and M. Duel. 1974. Selected geologic factors affecting mining of the Pittsburgh Coal. Bureau of Mines Report of Investigations 8093: 72. 
Metzgar, B. 2003. The Great Allegheny Passage Companion: Guide to History \& Heritage Along the Trail. Local History Company, Pittsburgh, PA. <http://www.thelocalhistorycompany.com/books/097118352x/pages/097118352x. html>

Mondal, N.C., V.P., Singh, V.S. Singh, and V.K. Saxena. 2010. Determining the interaction between groundwater and saline water through groundwater major ions chemistry. Journal of Hydrology 388, no. 3-4: 100-111.

Mook, W. G., and F.C. Tan. 1991. Stable carbon isotopes in rivers and estuaries. In Biogeochemistry of major world rivers, ed. E. Degens, S. Kempe, J. Richey, 245264. New York City, New York: John Wiley and Sons.

Mook, W.G. 2001. Environmental Isotopes in the Hydrological Cycle: Principles and Application 39, I: 1-271.

Moore, J. 2012. Potential inhibitors and sources of error in the measurement of travertine precipitation rates in a karst stream influenced by thermal mineral waters. MS Thesis, West Virginia University.

Mulder, M. 2012. Ambient Geochemical and Isotopic Variations in Groundwaters Across an Area of Accelerating Shale Gas Development. MS Thesis, West Virginia University.

Mutlu, H. 2007. Constraints on the Origin of the Bahkesir Thermal Waters (Turkey) from Stable Isotope $\left(\delta^{18} \mathrm{O}, \delta \mathrm{D}, \delta^{13} \mathrm{C}, \delta^{34} \mathrm{~S}\right)$ and Major-Trace Element Compositions. Turkish Journal of Earth Sciences 16:13-32.

Nordstrom, D.K., W.G. Write, M.A. Mast, D.J. Bove, and R.O. Rye. 2007. AqueousSulfate Stable Isotopes-A Study of Mining-Affected and Undisturbed Acidic Drainage, USGS Publication, Chapter E8. In Integrated Investigations of Environmental Effects of Historical Mining in the Animas River Watershed, San Juan County, Colorado. eds. S.E. Church, P. von Guerard, and S.E. Finger. O’ Leary, M.H. 1981. Carbon Isotope Fractionation in Plants. Phytochemistry 20, no. 4: 553-567.

Olivero, G.F., M. Zauli, and G. M. Zuppi . 1987. Isotopic composition and origin of sulfur compounds in groundwaters and brines in the Po Valley (Northern Italy). Studies on Sulphur Isotope Variations in Nature 1: 49-64. 
Osborn, S.G., and J.C. McIntosh. 2010. Chemical and isotopic tracers of the contribution of microbial gas in Devonian organic-rich shales and reservoir sandstones, northern Appalachian Basin. Applied Geochemistry 25, no. 3: 456-471.

Osborn, S.G., A.Vengosh, N.R. Warner, and R.B. Jackson. 2011. Methane Contamination of Drinking Water Accompanying Gas-Well Drilling and Hydraulic Fracturing. Proceedings of National Academy of Sciences 108, no. 20 : 1-9.

Park, R., and S. Epstein. 1961. Metabolic fractionation of ${ }^{13} \mathrm{C}$ and ${ }^{12} \mathrm{C}$ in plants. Plant Physiology 36: 133-138.

Palmer, S.M., D. Hope, M.F. Billett, J.J.C. Dawson, and C.L. Bryant. 2001. Sources of organic and inorganic carbon in a headwater stream: Evidence from carbon isotope studies. Biochemistry 52: 321-338.

Pang, Z. 2001. Isotope and chemical geothermometry and its applications. Science in China 44, no. 1: 16-20.

Panno, S.V., K.C. Hackley, K. Cartwright, and C.L. Liu. 1994. Hydrochemistry of the Mahomet Bedrock Valley Aquifer, East-Central Illinois: Indicators of Recharge and Ground-Water Flow. Ground Water 32, no. 4: 591-604.

Pentecost, A. 2005. Travertine. Dordrecht, Netherlands: Kluwer Academic Publishers Group.

Qin, D., J.V. Turner, and Z. Pang. 2005. Hydrogeochemsitry and groundwater circulation in the Xi' an geothermal field, China. Geothermics 34: 471-494.

Rader, E.K., and T.M. Gathright. 1984. Stratigraphy and Structure In the Thermal Springs Area of the Western Anticlines. Virginia Division of Natural Resources: 13-15.

Révész, K., and H. Qi. 2006. Determination of the $\delta\left({ }^{34} \mathrm{~S} /{ }^{32} \mathrm{~S}\right)$ of sulfate in water: RSIL Lab-Code1951. In Methods of the Reston Stable Isotope Laboratory 10: 10-33.

Roesler, A. J., C. H. Gammons, G. K. Druschel, H. Oduro and S. R. Poulson. 2007. Geochemistry of Flooded Underground Mine Workings Influenced by Bacterial Sulfate Reduction. Aquatic Geochemistry. DOI 10.1007/s10498-007-9017-9.

Rounds, S.A. 2006. Alkalinity and acid neutralizing capacity. U.S. Geological Survey TWRI Book 9, 3: 1-53. 
Rozanski, K., L. Araguás-Araguás, and R. Gonfiantini. 1993. Isotopic Patterns in Modern Global Precipitation. Geophysical Monograph 78: 1-36.

Schulte, P, R. van Geldern, H. Freitag, A. Karim, P. Négrel, E. Petelet-Giraud, A. Probst, J.L. Probts, K. Telmer, J. Veizer, and J.A.C. Barth. 2011. Applications of stable water and carbon isotopes in watershed research: Weathering, carbon cycling, and water balances. Earth-Science Reviews 109, no. 1-2: 20-31.

Seal, R.R., C. N. Alpers, and R.O. Rye. 2000. Stable isotope systematics of sulfate minerals. In Sulfate Minerals: Crystallography, Geochemistry, and Environmental Significance. Reviews in Mineralogy and Geochemistry Volume 40:541-602. eds. Alpers CN, Jambor JL, Nordstrom DK. Mineralogical Society of America and Geochemical Society, Washington, D.C.

Seal, R.R. 2003. Stable -isotope geochemistry of mine waters and related solids. In Environmental Aspects of Mine Wastes, 303-334. eds. Jambor, J.L., Blowes, D.W., Ritchie, A.I.M. Mineralogical Association of Canada Short Course.

Seal, R.R. 2006. Sulfur Isotope Geochemistry of Sulfide Minerals. Reviews in Mineralogy \& Geochemistry 61: 633-677.

Sharma, S., M. Mulder, A. Sack, K. Schroeder and R. Hammack. Unpublished. Assessing changes in hydrologic isolation of formations during Marcellus shale gas drilling: a stable isotope approach, Groundwater.

Sharma, S., A. Sack, J. Adams, D. Vesper, R. Cap, A. Hartsock and H. Edenborn. 2012. Isotopic evidence of enhanced carbonate dissolution at a coal mine drainage site in Allegheny County, Pennsylvania USA, Applied Geochemistry.

Sharma, S., and C.D. Frost. 2008. Tracing Coalbed Natural Gas-Coproduced Water Using Stable Isotopes of Carbon, Ground Water 46, no. 2: 329-334.

Sharma S., and J. Baggett. 2011. Application of carbon isotopes to detect seepage out of coalbed natural gas produced water impoundments. Applied Geochemistry 26, no. 8: 1423-1432.

Siegel, D.I., R.J. Szustakowski, and S. Frape. 1990. Regional appraisal of brine chemistry in the Albion Group sandstones (Silurian) of New York, Pennsylvania, and Ohio: Association of Petroleum Geochemical Explorations Bulletin 6: 66-77. 
Siegel, D.I., K.A. Lesniak, M. Stute, and M. Frape. 2004. Isotopic geochemistry of the Saratoga Springs: Implications for the origin of solutes and source of carbon dioxide, Geology 32, no. 3: 257-260.

Simpkins, W.W., and T.B. Parkin. 1993. Hydrogeology and redox geochemistry of CH4 in a late Wisconsinian till and loess sequence in central Iowa. Water Resources Research 29, no. 11: 3643-3657.

Soeder, D.J., and W.M. Kappel. 2009. Water Resources and Natural Gas Production from the Marcellus Shale. USGS Fact Sheet 3032: 1-6.

Soubbotin, T.P., and K.A. Sheram. 2000. Beyond Economic Growth, The International Bank for Reconstruction and Development/The World Bank, 17-22.

Taylor, B.E., M.C. Wheeler, and D. K. Nordstrom. 1984. Isotope Composition of Sulphate in Acid Mine Drainage as Measure of Bacterial Oxidation. Nature 308: 538-541.

Taylor, B.E., and M.C. Wheeler. 1994. Sulfur- and Oxygen-Isotope Geochemistry of Acid Mine Drainage in the Western United States. In Environmental Geochemistry of Sulfide Oxidation, 481-514. eds. C. N. Alpers and D. W. Blowes, ACS Symposium Series 550.

ThermoFinnigan. 2001. GasBench II: Automated $\mathrm{H}_{2} / \mathrm{H}_{2} \mathrm{O}$ equilibration for $\delta \mathrm{D}$ determination of aqueous samples. Application Flash Report No. G 32 .

Thermo Electron Corporation. 2004. Finnigan GasBench II brochure. <http://es.ucsc.edu/ silab/ThermoManuals/Gas\%20Bench/1118342_GasBench_I _Operating_Manual.pdf>

Toran, L., and R.F. Harris. 1989. Interpretation of Sulfur and Oxygen Isotopes in Biological and Abiological Sulfide Oxidation. Geochimica et Cosmochimica Acta 53, no. 9: 2341-2348.

Torres, M.E., A.C. Mix, and W.D. Rugh. 2005. Precise $\delta^{13} \mathrm{C}$ analysis of dissolved inorganic carbon in natural waters using automated headspace sampling and continuous-flow mass spectrometry. Limnology and Oceanography Methods 3: 349-360. 
Trembaczowski, A., J. Szaran, and H. Niezgoda. 2004. Investigating the Provenance and Seasonal Variations in Sulphate Sulphur and Oxygen Isotopes of Central Roztocze River Water, SE Poland. Water, Air, and Soil Pollution 157: 65-84.

U.S. DOE. 2011. A comparative study of the Mississippian Barnett shale, Fort Worth basin, and Devonian Marcellus shale, Appalachian basin. DOE/NETL-2011/1478, U.S. Department of Energy: Washington, D.C.< http://www.netl.doe.gov/technologies/oil-gas/publications/brochures/DOENETL-2011-1478\%20Marcellus-Barnett.pdf>

U.S. Environmental Protection Agency (EPA). Appendix C Regional Setting Supporting Information, Mountain Mining Valley Fill in Appalachia EIS. United States Environmental Protection Agency, 1-54. <www.epa.gov/region3/mtntop/pdf/appendices/c/appc.pdf>

U.S. Environmental Protection Agency (EPA). 1995. Cleaner Water Through Conservation. Office of Wetlands, Oceans, and Watersheds (OWOW), EPA 841B-95-002: 1-70.

U.S. Environmental Protection Agency (EPA). 2008. Mining Operations as Nonpoint Source Pollution. EPA, Washington, D.C. <http://www.epa.gov/reg3wapd/nps/mining.html>

USGS, Water Use in the United States. 2005. USGS Water Science. <http://ga.water.usgs.gov/edu/wateruse.html>

USGS, Valley and Ridge Provenance. <http://3dparks.wr.usgs.gov/nyc/valleyandridge/valleyandridge.htm>

USGS, Mineral Resources On-Line Spatial Data. <http://mrdata.usgs.gov/> van Donkelaar, C,V., I.E. Hutcheon, and H. R. Krouse. 1995. $\delta^{34}$ S, $\delta^{18} \mathrm{O}, \delta \mathrm{D}$ in Shallow Groundwater: Tracing Anthropogenic Sulfate and Accompanying Groundwater/Rock Interactions. Water, Air, and Soil Pollution 79: 279-298. van Everdingen, H.R., and H.R. Krouse. 1985. Isotope Composition of Sulphates Generated by Bacterial and Abiological Oxidation. Nature 315: 395-396. van Stempvoot, D.R., and H. R. Krouse. 1994. Controls of $\delta^{18}$ O in Sulfate: Review of Experimental Data and Application to Specific Environments. In Environmental 
Geochemistry of Sulfide Oxidation, 466-480. eds. C. N. Alpers and D. W. Blowes, ACS Symposium Series 550.

Warner, N.R., R.B. Jackson, T.D. Darrah, S.G.Osborn, A. Down, K. Ahao, A. White, and A. Vengosh 2012. Geochemical evidence for the possible natural migration of Marcellus brine to shallow drinking water in Pennsylvania. Proceedings of the National Academy of Sciences 109, no. 30: 11961-11966.

Whiticar, M.J., E. Faber, and M. Schoell. 1986. Biogenic Methane Formation in Marine and Freshwater Environments: $\mathrm{CO}_{2}$ Reduction vs. Acetate Fermentation Isotopic Evidence. Geochimica et Cosmochimica Acta 50, no. 5: 693-709.

Whiticar, M.J. 1999. Carbon and hydrogen isotope systematic of bacterial formation and oxidation of methane. Chemical Geology 161, no. 1-3: 291-314.

Wieser, M.E., and W.A. Brand. 1999. Isotope Ratio Studies Using Mass Spectrometry. In Encyclopedia of Spectroscopy and Spectrometry, 1072-1086. eds. J. C. Lindon, G. E. Tranter, and J. L. Holmes: Academic Press.

Wilson, T.P., and D.T. Long. 1993. Geochemistry and isotope chemistry of Michigan Basin brines: Devonian formations. Applied Geochemistry 8, no. 1: 81-100.

Wittrup, M.B., T.K. Kyser, and T. Danyluk. 1987. The Use of Stable Isotopes to Determine the Sources of Brines in Saskatchewan Potash Mines. Economic Minerals of Saskatchewan, 159-165.

Wright, W.G., and D.K. Nordstrom. 1999. Oxygen isotopes of dissolved sulfate as a tool to distinguish natural and mining related dissolved constituents. In Tailings and Mine Waste, 671-678.

Zhang T., and B.M. Krooss. 2001. Experimental Investigation on the Carbon Isotope Fractionation of Methane During Gas Migration by Diffusion through Sedimentary Rocks at Elevated Temperature and Pressure. Geochimica et Cosmochimica Acta 65, no. 16: 2723-2742. 